\title{
Analyzing Fracture Stimulation of Middle Devonian Strata in Clearfield County Pennsylvania Using a 3D Geomechanical Fault Model and Microseismic
}

\author{
Cole E. Bowers
}

Follow this and additional works at: https://researchrepository.wvu.edu/etd

\section{Recommended Citation}

Bowers, Cole E., "Analyzing Fracture Stimulation of Middle Devonian Strata in Clearfield County Pennsylvania Using a 3D Geomechanical Fault Model and Microseismic" (2014). Graduate Theses, Dissertations, and Problem Reports. 5243.

https://researchrepository.wvu.edu/etd/5243

This Thesis is protected by copyright and/or related rights. It has been brought to you by the The Research Repository @WVU with permission from the rights-holder(s). You are free to use this Thesis in any way that is permitted by the copyright and related rights legislation that applies to your use. For other uses you must obtain permission from the rights-holder(s) directly, unless additional rights are indicated by a Creative Commons license in the record and/ or on the work itself. This Thesis has been accepted for inclusion in WVU Graduate Theses, Dissertations, and Problem Reports collection by an authorized administrator of The Research Repository @ WVU. For more information, please contact researchrepository@mail.wvu.edu. 


\title{
Analyzing Fracture Stimulation of Middle Devonian Strata in Clearfield County Pennsylvania Using a 3D Geomechanical Fault Model and Microseismic.
}

\section{Cole E. Bowers}

\author{
Thesis submitted to the \\ College of Arts and Sciences \\ at West Virginia University \\ in partial fulfillment of the requirements \\ for the degree of \\ Masters of Science \\ In \\ Geology \\ Dr. Timothy R. Carr, Ph. D., Chair \\ Dr. J. Ryan Shackleton, Ph. D., Co-Chair \\ Peter Sullivan, M.S. \\ Department of Geology and Geography \\ Morgantown, West Virginia \\ 2014
}

Keywords: Fracture Stimulation; Middle Devonian; Marcellus Shale; 3D seismic; Microseismic; Mechanical Stratigraphy; Appalachian Basin Copyright 2014 Cole Bowers 


\section{Abstract \\ Analyzing Fracture Stimulation of Middle Devonian Strata in Clearfield County Pennsylvania Using a 3D Geomechanical Fault Model and Microseismic.}

\section{Cole E. Bowers}

The Middle Devonian Marcellus Formation in the Appalachian basin is a world class unconventional reservoir. The Marcellus Formation in Clearfield County, Pennsylvania has comparable thickness, depth, reservoir pressure, total organic carbon, and thermal maturity in comparison to other areas within the Appalachian basin. However, lower natural gas production is observed in this area. Structural complexity, natural fracturing, and rock mechanics in the study area negatively affect fracture stimulation, and can potentially hinder gas production. Two fault models using depth converted 3D seismic highlight structural complexity. A geomechanical model, and microseismic analysis using $\mathrm{r}(\mathrm{t})$ plots, and b-values highlight effects of natural fracturing. During stage two of the microseismic well, hydraulic connectivity occurred within a fault damage zone related to a cross-strike, strike-slip fault. Triaxial strain core tests and rock property determination from well logs highlight brittle and ductile shale zones. 


\section{Acknowledgements}

Most of all I would like to thank God for giving me the strength to finish this research and I would like to state that all of the content within this research does not reflect my beliefs in any way. Now, I would like to thank Dr. Carr, Dr. Shackleton and Peter Sullivan for all of the guidance during my master's thesis. I would also like to thank my father Duane Bowers who introduced me to geology at an early age. Also I would like to thank Shuvajit Bhattacharya who was always willing to discuss certain aspects of my research. I would like to thank Joe Filchock for all his help in gathering the Pennsylvania production data and for helping me with coordinate conversions. Also, I would like to thank the Department of Geology and Geography of West Virginia University which supplied monetary support over the fall 2013 and spring 2014 semesters Finally, I would like to thank Energy Corporation of America for providing the data that was analyzed for this research. 


\section{Table of Contents}



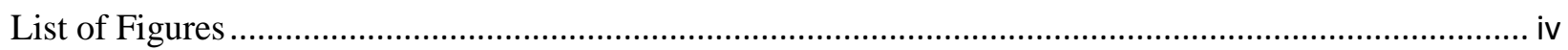

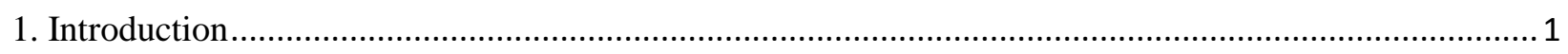

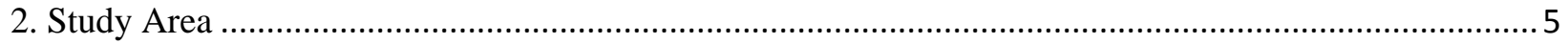



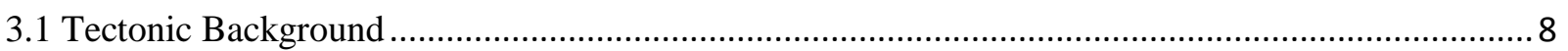

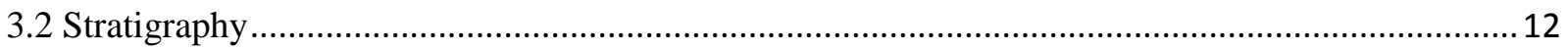



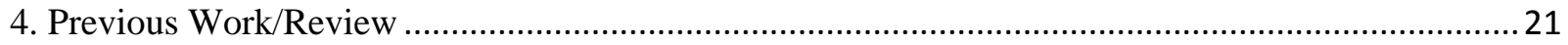

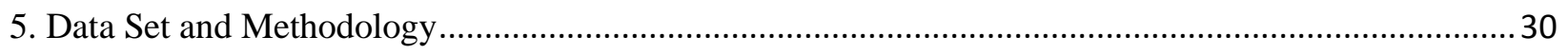

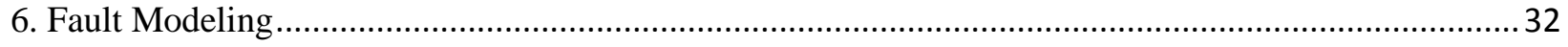

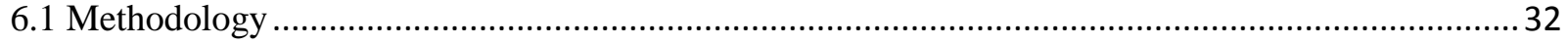

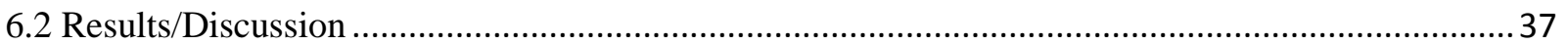

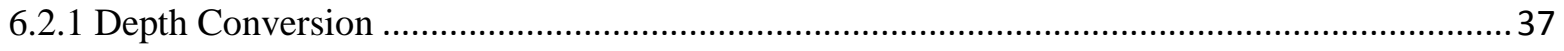



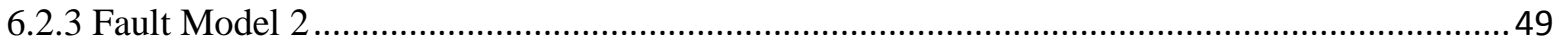

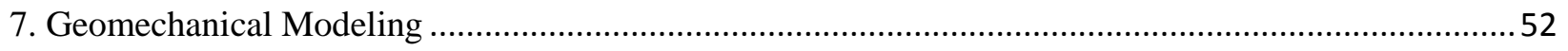

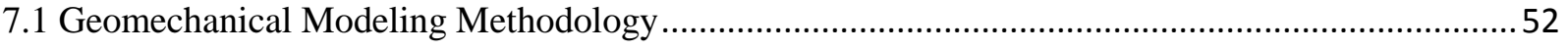

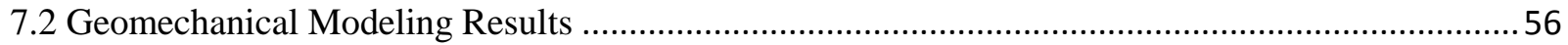



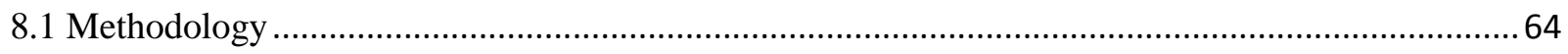

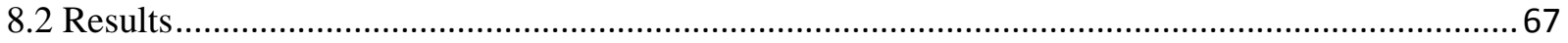

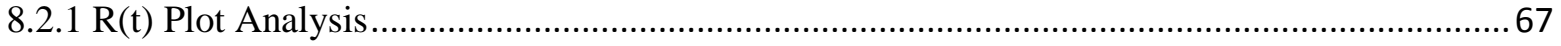



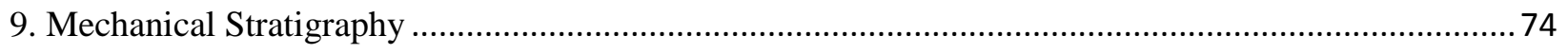



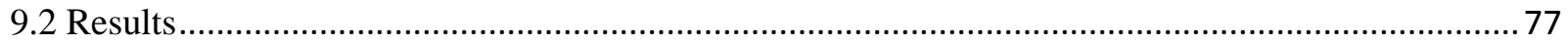

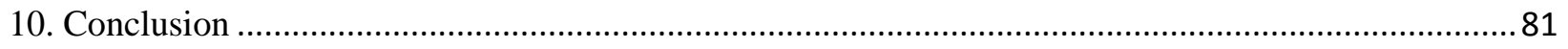

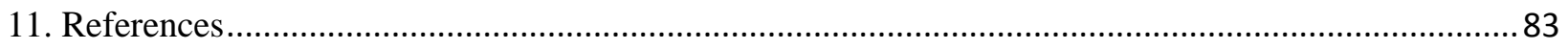




13. Appendix B. Allan Mapping Displacements for Along-strike Faults ................................................90

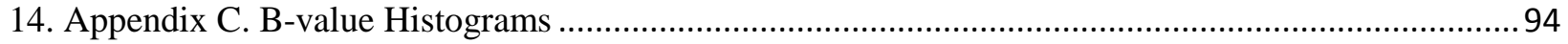




\section{List of Figures and Tables}

Figure 1. Horizontal wells and locations drilled for the Marcellus Formation in the Appalachian basin... 2

Figure 2. Horizontal well production in Pennsylvania over the second year production..... 3

Figure 3. Surface folds and faults in Pennsylvania (highlights Clearfield County) (Pennsylvania

Department of Conservation and Natural Recourses).

Figure 4. Surface folds and faults mapped in Clearfield County (Pennsylvania Department of Conservation and Natural Recourses).

Figure 5. Sequential tectonic model of the Appalachian orogeny (Modified from Marshak, 2010). ........11

Figure 6. Central Pennsylvania stratigraphy (King, 2014)............................................................. 15

Figure 7. Cross section of imbricate thrust and back thrust faulting in the core of the Chestnut Ridge anticline in the Appalachian basin (Scanlin and Engelder, 2005).

Figure 8. Model for kink band structures within the Appalachian Plateau (Gillespie et al., 2013).......... 17

Figure 9. Clearfield County with surface mapped cross-strike, strike-slip structures (Faill et al., 1989).. 18

Figure 10. Map and cross-section view of strike-slip clusters in Clearfield County, Pennsylvania (Faill et al.,1989). . .19

Figure 11. Cross fold joint development in the Appalachian Plateau (Zhao and Jacobi, 1997)...............20

Figure 12. Regional Onondaga structure map within the Appalachian Basin (Zagorski et al., 2012)....... 25

Figure 13. Regional Pressure gradient map within the Appalachian Basin (Zagorski et al., 2012)...........26

Figure 14. Regional Marcellus thickness map within the Appalachian Basin (Zagorski et al., 2012)...... 27

Figure 15. Regional Marcellus net thickness of organic shale containing seven percent organic carbon.

(Yanni, 2010).

Figure 16. Regional Marcellus net thickness of organic shale contanting seven perecent organic carbon.

(Boyce, 2010)....

Figure 17. Thermal maturity map of the Marcellus Formation within the Appalachain basin (Zagorski et al., 2012).

Figure 18. (a) Neural network solution for all organic facies thickness. (b) Neural network for all brittle





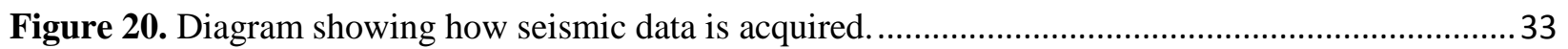

Figure 21. Surfaces used for the velocity model ............................................................................ 34

Figure 22. Parameters for the velocity model and depth conversion of the post-stack 3D seismic ........... 34

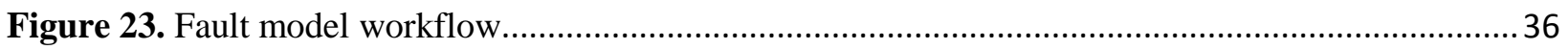

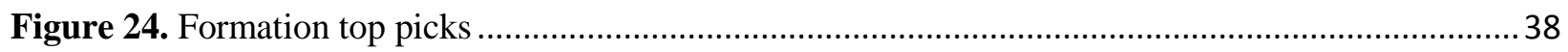

Figure 25. Synthetic seismogram produced in SMT ${ }^{\mathrm{TM}}$ software ........................................................ 39

Figure 26. Rose diagram showing fault orientations for this data set .................................................. 40

Figure 27. Stratigraphic column showing the stratigraphy within cross-sections................................... 43

Figure 28. Onondaga horizon (Base Marcellus) with the faults picked in Fault model 1........................44

Figure 29. Fault Model 1 Cross-sections A-D ............................................................................... 46

Figure 30 a) Sequential model of a fault propagation fold (Mitra, 1990). b) Sequential model of a break



Figure 31. The final outcome from Fault model 1 ........................................................................... 48 
Figure 32. Onondaga horizon (Base Marcellus) horizon in Fault model 2 ...........................................50

Figure 33. Fault model 2 cross-sections A - B ................................................................................. 51

Figure 34. Geomechanical modeling workflow ............................................................................. 52

Figure 35. Mass spring solver workflow adopted from Midland Valley Move ${ }^{\mathrm{TM}}$ software. ....................54

Figure 36. a) Resampled triangle mesh b) Quality check of the resampled meshes in Fault model 2....56

Figure 37. a) Horizons used in the mass spring algorithm b) Restored Marcellus horizon.......................57

Figure 38. Geocellular model showing E1 attribute. .................................................................5

Figure 39. a) Marcellus E1 strain attribute horizon b) Marcellus E1/E3 strain attribute horizon ............60

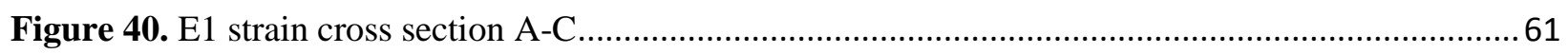

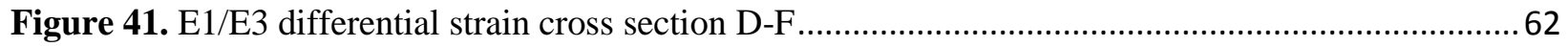

Figure 42 a) Observed strike-slip damage zones modified from (Kim and Sanderson, 2005). b)

Interpreted strike-slip fault at the base of the Marcellus Formation with E1 damage zones at the fault tips

c) Interpreted strike-slip fault at the base of the Marcellus Formation with differential strain E1/E3



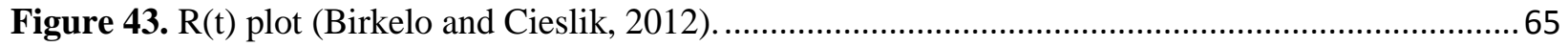



Figure 45. Stage $2 \mathrm{r}(\mathrm{t})$ plot with pumping data and microseismic data.................................................6 68

Figure 46. a) Volume of rock that experienced seismicity b) Estimated stimulated reservoir volume .....68

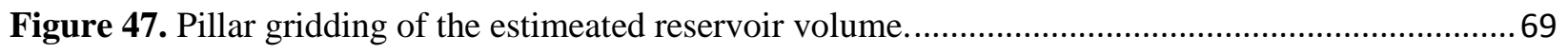

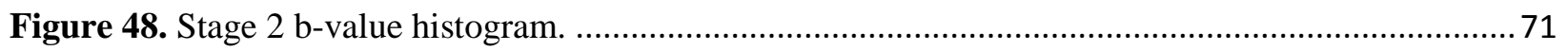

Figure 49. Bar chart showing the b-values for a thirteen stages ..................................................... 71

Figure 50. E1 strain map within the Marcellus Formation with all microseismic events........................ 72

Figure 51. E1 strain map within the Moscow Formation and stage 2 seismicity.................................... 72

Figure 52. 3D view of all microseismic events indicating effective fracture barriers. ............................73

Figure 53. Frequency histogram of events plotted by depth indicating a bimodal distrubtion..................73

Figure 54. Example of triaxial strain test results. Modified from (Fox et al., 2013)............................... 75

Figure 55. Triaxial strain tests for the cored well. ....................................................................... 78

Figure 56. Brittleness curves derived from dipole sonic and denisy logs .............................................79

Figure 57. Well $\log$ with $\mathrm{Th} / \mathrm{K}$ spectral gamma-ray $\log$ and microseismic event frequency..................... 80

Table 1. Equation for mechanical rock properties in well logs (Bateman, 2012) ..................................75 


\section{Introduction}

The Marcellus Formation and other unconventional shale gas units in the Appalachian basin have had a significant and growing impact on the United States natural gas industry since 2006, when the first operationally successful horizontal Marcellus well was completed (Zagorski et al., 2012). Estimated recoverable gas within the Marcellus ranges from 50 to 500 trillion cubic feet (tcf), with trends in initial gas production per well ranging from 0.3 to 26 million cubic feet per day (mmcfpd) (Zagorski et al., 2012). While the entire basin has seen activity, drilling has been concentrated in two areas that correlate to higher initial production rates. These areas are in southwest Pennsylvania and north-central West Virginia, and northeast Pennsylvania (Figure 1). However, other areas of the Appalachian basin including Clearfield County, Pennsylvania have lower drilling density, and lower initial production rates (personal communication with Peter Sullivan, Energy Corporation of America). While initial flow rates in mmcf/day are a better way to compare production of wells such data is not easily obtainable throughout the basin. However, using semi-annual production from the Pennsylvania Department of Environmental Protection a map is constructed using production over a 335 to 365 day period during the second year of a well's production, and shows that higher production is focused in southwestern and northeastern Pennsylvania (Figure 2). 


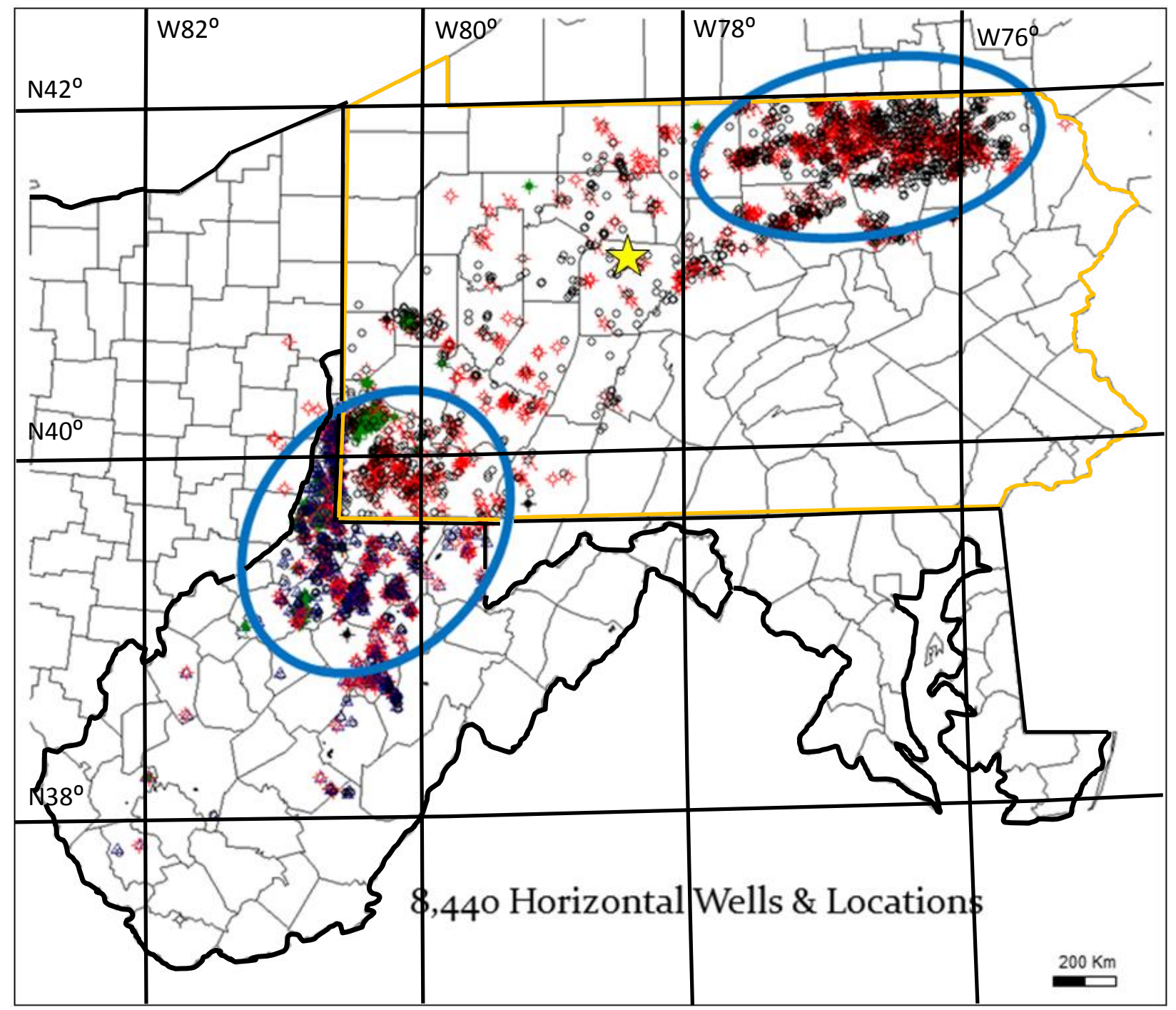

Figure 1. Horizontal wells and locations drilled for the Marcellus Formation in the Appalachian basin. Drilling activity is concentrated in southwest Pennsylvania and north-central West Virginia, and northeast Pennsylvania (highlighted with blue ovals). This study is located in Clearfield County, Pennsylvania, an area of lower drilling density (highlighted with a star). State of Pennsylvania highlighted in yellow. 


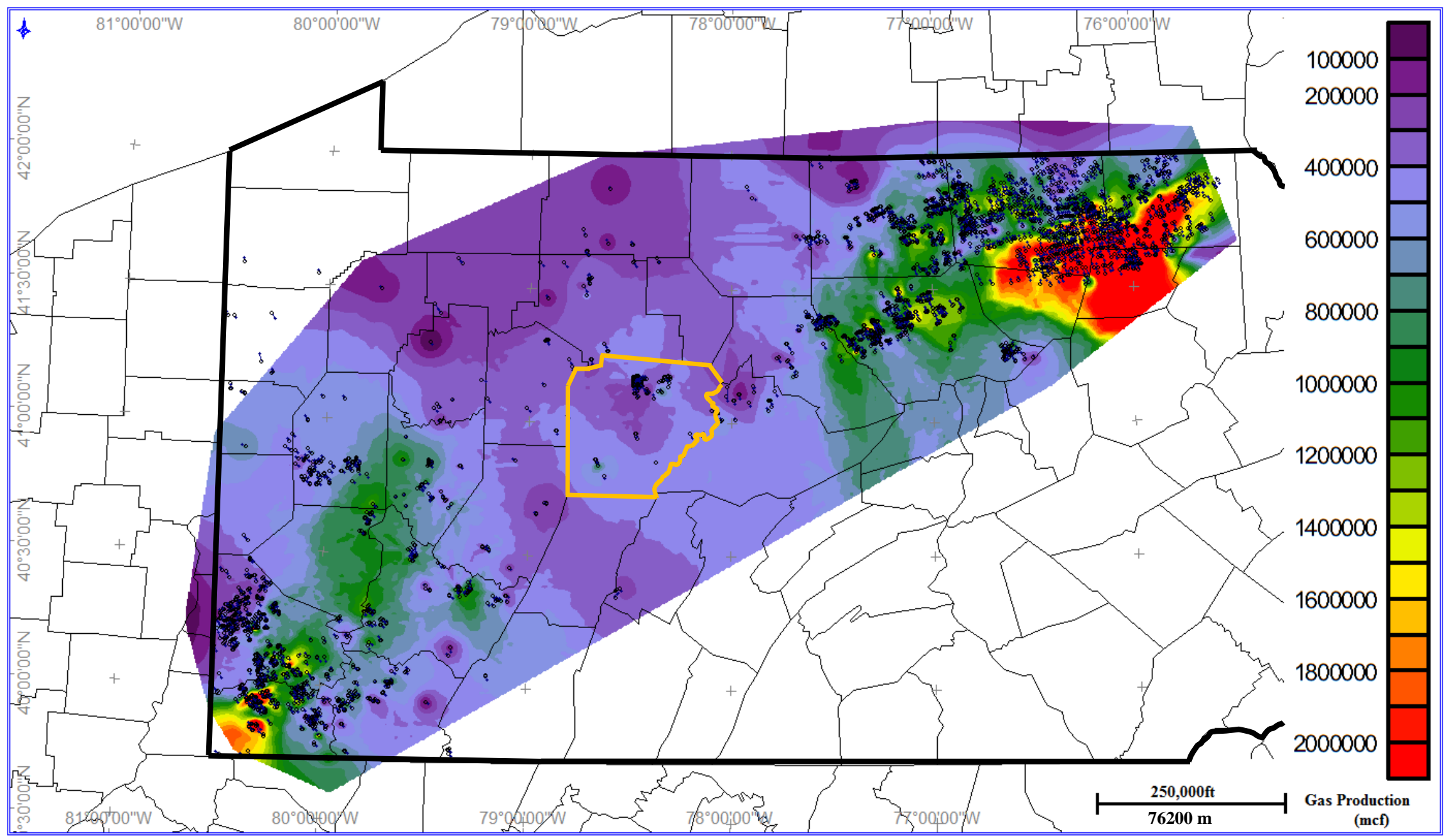

Figure 2. Horizontal well production in Pennsylvania normalized over the second year of a well's production (minimum of 335 days to 365 producing days). Notice western Washington County has less gas production but this data is biased because this is an area of increased natural gas liquids production. Clearfield County is highlight in yellow. 
There are numerous geologic factors that affect production capability of unconventional shale reservoirs including:

\section{Depth}

2. Pressure Gradient

3. Thickness

4. Total organic content

5. Thermal Maturity

6. Porosity and permeability

7. Gas show characteristics or gas in place

8. Mineralogy/Lithology

9. Structural complexity

10. Natural fracturing

11. Rock mechanics

(Slatt, 2012; Williams-Stroud and Eisner, 2010; Rickman et al., 2009; Fox et al., 2013; Engelder et al., 2009; Zagorski et al., 2012). Geologic factors define the initial conditions of unconventional shale reservoirs, and the effectiveness of hydraulic stimulation. In the study area of Clearfield County Pennsylvania, it appears that geologic factors such as rock mechanical properties, preexisting natural fractures and structural complexity exert a high degree of control on stimulation efficiency and productivity.

In this research, I provide a short discussion on Appalachian basin history and proposed techniques to examine the available data. Available geologic and petrophysical data in the study area include; post-stack 3D seismic, well logs, core samples, completion reports, and microseismic. Seismic analysis includes a detailed fault model and geomechanical model. Well 
$\log$ analysis provides geomechanical properties, which are tied to core data. Microseismic data is mapped in comparison to the fault model and vertical rock property trends.

\section{Study Area}

This research located in central Pennsylvania is focused within Clearfield County, Pennsylvania (Figure 3). The fault model, geomechanical model and microseismic analysis are constrained to northern Clearfield County within a thirty-five square mile post-stack 3D seismic data set, while the well log analysis covers all of Clearfield County. Major surface structural features observed across the study area include multiple long continuous anticlines and synclines and strike-slip faults. Surface geologic mapping indicates that the Chestnut Ridge anticline terminates within the center of the 3D seismic data set, and strike-slip faults terminate less than two miles south of the data set (Figure 4). 


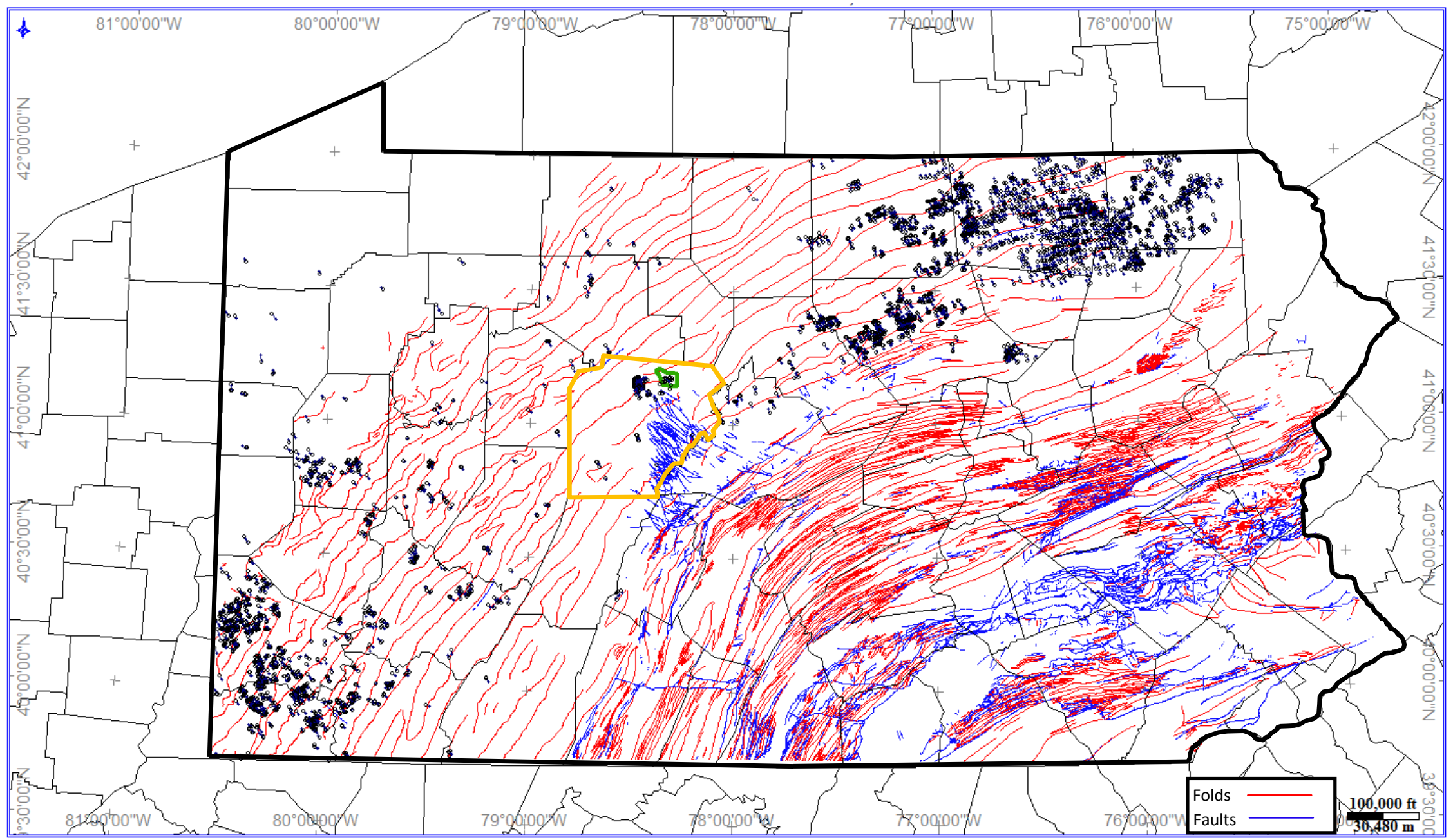

Figure 3. The study area for this data set is located in Clearfield County, Pennsylvania (highlighted in yellow). The location of the fault model, geomechanical model and microseismic analysis are in northern Clearfield County (highlighted in green). Fold axis are displayed in red and fault locations are displayed in blue (Pennsylvania Department of Conservation and Natural Recourses). 


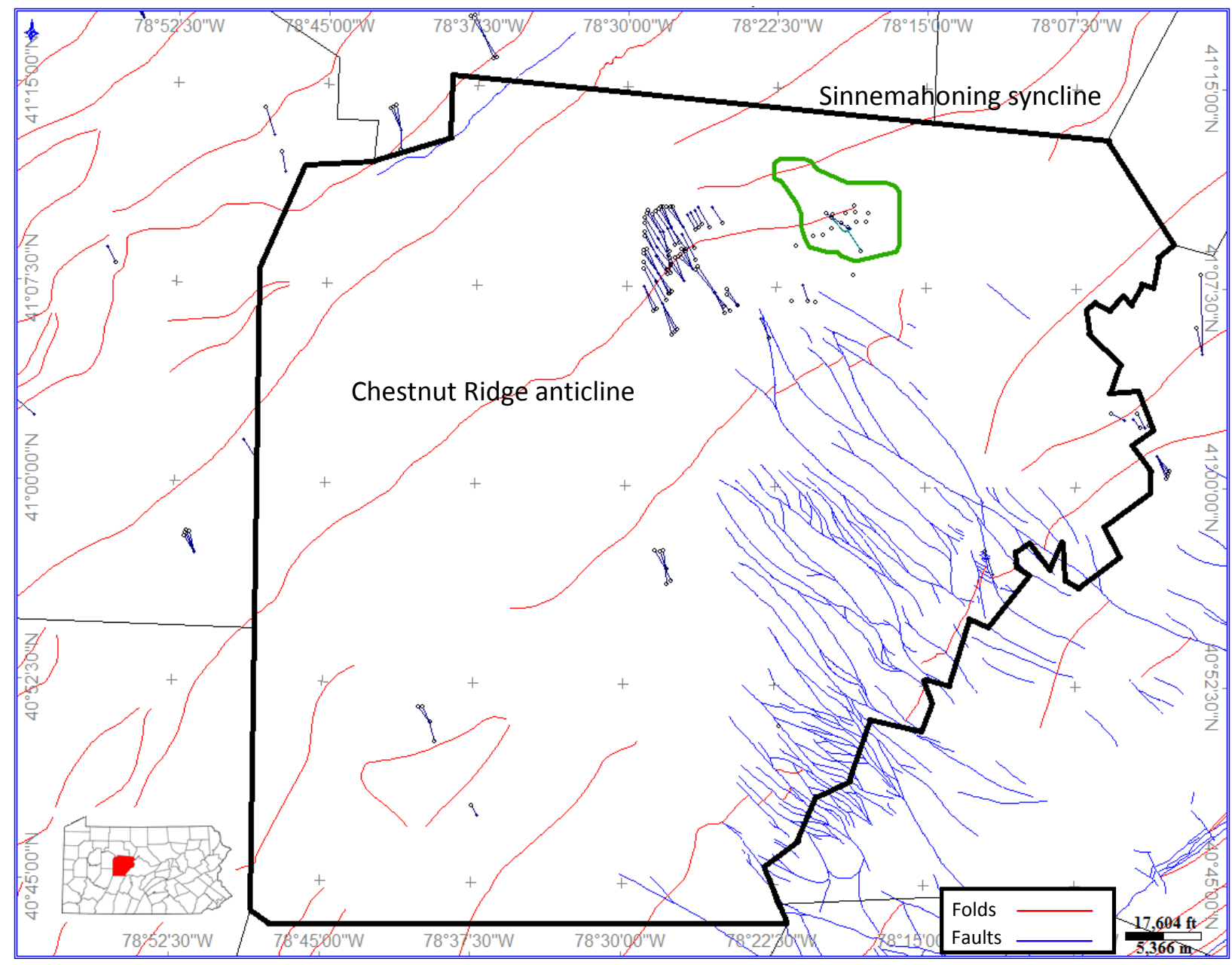

Figure 4. Surface folds and faults mapped in Clearfield County. The Chestnut Ridge anticline terminates within the 3D seismic data set and the Sinnemahoning syncline crosses through the data set. Surface mapped strike-slip faults terminate two miles south of the 3D seismic data set. Wells are shown by circles and lines connecting top hole and bottom hole location (Pennsylvania Department of Conservation and Natural Recourses). 


\section{Geologic Background}

\subsection{Tectonic Background}

The Appalachian orogen extends from central Alabama to the Newfoundland and Labrador provinces of Canada. The Appalachian orogen was shaped by six individual tectonic events. They include;

- Late Mesoprorterozoic ( 1100 Ma) Grenville orogenesis,

- Neoproterozoic ( 600 Ma) and Middle Cambrian ( $500 \mathrm{Ma})$ Rome trough and Catoctin rifting,

- Middle Ordovician ( 470 Ma) Taconic orogenesis,

- Middle Devonian ( $390 \mathrm{Ma})$ Acadian orogenesis,

- Pennsylvanian ( 320Ma) Allegheny orogenesis and

- Late Triassic ( 210 Ma) extension (Faill,1997a \& b).

Grenville orogenesis (1200 Ma $-1000 \mathrm{Ma})$ contributed to the development of the supercontinent of Rodinia (Faill, 1997; Whitmeyer and Karlstrom, 2011). Plate convergence consisted of multiple stages of deformation including; plate docking and obduction that accreted various terranes on eastern Laurentia resulting in large scale deformation, metamorphism of older crustal rocks and younger sedimentary rocks, and plutonic activity occurred (Faill, 1997a). Increased magmatism and mineralization during Grenville orogenesis provided sediment sourcing for the later orogenic events. For example, the Acadian orogeny related Middle Devonian Tioga Ash beds contain Grenville aged zircons (Hayward, 2012). Also, detrital zircon frequency-probability plots show that the Allegheny orogeny related Permian Dunkard Group has a dominate signature from $1300 \mathrm{Ma}-1000 \mathrm{Ma}$ indicating that many of the youngest recycled 
orogen deposits in the Appalachian basin are related to Grenville magmatism and mineralization (Becker et al., 2006).

During the Late Neoproterozoic to Middle Cambrian rapid extension and rifting occurred in association with the breakup of Rodinia and the opening of the Iapetus-Theic ocean (Faill, 1997a). This rifting produced two large extensional features known as the Catoctin rift and the Rome trough (Faill, 1997a). The Catoctin rift (Neoproterozoic) is observable near the Blue Ridge province and consists of syn-rift volcanics in the Catoctin formation and syn-rift sedimentary packages in the Chilhowee Group (Faill, 1997a). The Rome trough (Early to Middle Cambrian) is within the Appalachian basin and is a supplement to the Catoctin rift (Faill, 1997a). Extensional fault movement related to the Rome trough slowed tremendously from the Middle Ordovician to the Pennsylvanian. However, faults have been interpreted to reactivate and extend into the Middle Devonian Elk Group (Kulander and Ryder, 2005). From the Late Cambrian to Middle Ordovician a sag basin was formed, caused by post-rift thermal contraction on the passive continental margin (Figure 5) (Gao et al., 2000).

Evidence for the beginning stages of the Taconic orogeny includes the post-Knox unconformity, which can be seen throughout most of the Appalachian basin (Bridge, 1955; Milici,1973; Harris and Repetski, 1983; Mussman and Read, 1986). This unconformity marks the end of passive margin deposition and the birth of foreland basin deposition in the Appalachian basin (Rodgers, 1971; Shanmugam and Lash, 1982; Wehr and Glover, 1985). The unconformity represents a large crustal bulge caused by the initial loading on the continental margin through accretion of various magmatic arcs, microcontinents and accretionary prisms (Faill, 1997b). Tectonic activity was prominent from the middle to late Ordovician (Figure 5). 
However, from the Silurian to the early Devonian siliciclastic deposition waned dramatically, indicating a more tectonically quiescent period (Milici, 1996; Faill, 1997a).

The Acadian orogeny began in the middle Devonian and ended in the early Mississippian (Figure 5) (Milici, 1996). During this mountain building event the Avalonia microplate collided with Laurentia resulting in deposition of the Catskill delta. This subaqueous delta is responsible for forming the predominately marine middle Devonian to late Mississippian sequence (Faill, 1985). Abrupt basal contacts under black shale deposition throughout the Acadian foreland are an indication of increased tectonic loading leading to rapid flexural subsidence (Ettensohn, 1987). Most of the deformation during the Acadian orogeny began in the middle Devonian and diminished by the late Devonian. However, interpretations of late Acadian or (Neoacadian) deformation has been observed in K-Ar dating related to the Mine Ridge and the Tucquan antiform found within the Piedmont province (Lapham and Bassett, 1964; Faill,1997b) Extending into the Appalachian Plateau recent 3D seismic observations support an interpretation for Neoacadian deformation (Harrison et al., 2004; Jacobi, 2013).

The Alleghenian orogeny began in the late Mississippian as the east coast of Laurentia was undergoing a transpressional collision with Gondwana (West Africa) (Figure 5) (Hatcher Jr., 2009). Deposition within the foreland took a major shift within the foreland during Allegheny orogenesis transforming from a deep marine and shallow marine environment to a predominately non marine environment (shallow shelf, deltaic, estuarine, or marsh depositional environment) (Milici, 1996). This large continental collision transmitted large amounts of strain into the foreland (Valley and Ridge and Appalachian Plateau) by blind thrust detachment faulting. Detachment faulting originated at the core of the suture in the ancient Allegheny Mountains somewhere between Laurentia and Gondwana (present day coastal plain province). As strain was 
translated into the foreland the blind thrusting stepped upward from deep within the crust in the Piedmont province to Cambrian aged shale in the Valley and Ridge province to the Salina salt within the Appalachian Plateau (Faill, 1998). While deformation was prominent much of the accommodation space in the foreland already had been filled from the past orogenies. Therefore, the sedimentary packages related to the Allegheny orogeny are not as thick in comparison to the Acadian and Taconic related deposits.

E. LATE MISSISSIPIAN
to LATE PERMIAN
320-250 Ma ago
Alleghenian Orogeny

D.

LATE DEVONIAN

\%70 Ma ago

Acadian Orogeny

C.

LATE SILURIAN

$\sim 420 \mathrm{Ma}$ ago

B.

ORDOVICIAN

500-440 Ma ago

Taconic Orogeny

A.

CAMBRIAN

570-500 Ma ago

Passive Margin
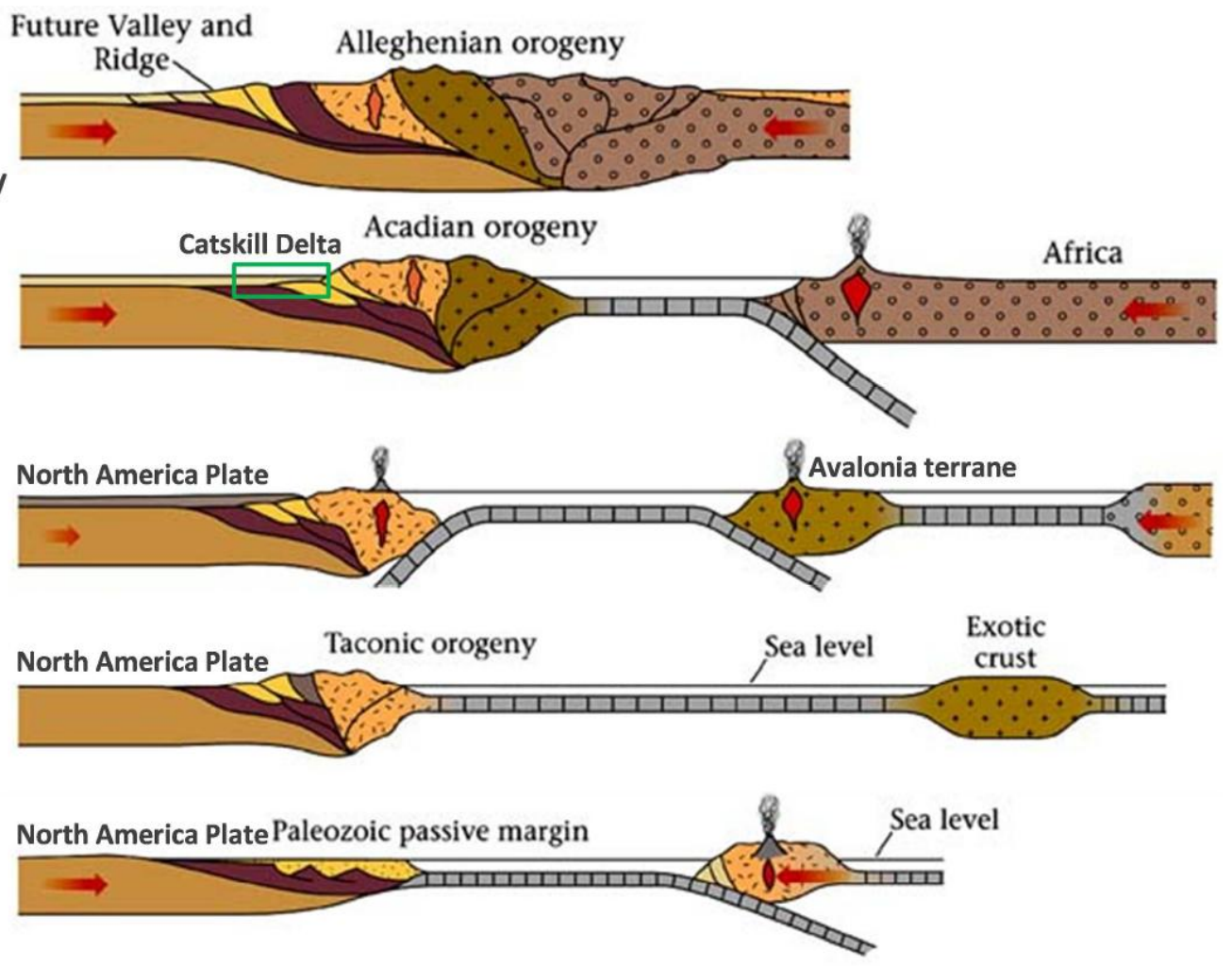

Figure 5. Sequential tectonic model of the Appalachian orogeny from the Cambrian through the late Permian. Step A in the model shows passive margin deposition after the breakup of Rodinia. Step B shows the active Taconic orogenesis. Step C shows tectonic quiescence in the Silurian. Step D shows Acadian orogenesis and the resultant Catskill delta foreland basin deposits. Step E shows Alleghenian orogenesis at its peak from late Mississippian to late Permian (Modified from Marshak, 2010). 


\subsection{Stratigraphy}

The stratigraphy of the Appalachian basin is largely controlled by tectonic activity. This section highlights the different strata within the Appalachian basin including strata from the Cambrian to Permian and relation to orogenesis (Figure 6). Devonian and Silurian strata will be covered in greater detail because these units influence structure within the highly targeted Marcellus Formation.

During the Cambrian and early Ordovician a foreland basin was not present and only passive margin deposition dominated eastern Laurentia. Five main sedimentary packages were deposited including the Rome Formation, Conassauga Shale, Copper Ridge Dolomite, Rose Run Sandstone, and the Beekmantown Group. The Rose Run has been targeted as a conventional reservoir and the Conassauga Shale has potential as an unconventional play.

Above the post-Knox unconformity lies the shallow marine to deep marine deposits of the Wells Creek Dolomite, Black River and Trenton Limestone, and the Point Pleasant/Utica Shale (Milici, 1997). Rapid subsidence during the Taconic orogeny flooded a carbonate shelf. Sea-level rise (transgression) can be observed in the gradually fining upward sequence of the shallow marine deposits of the Trenton/Black River Limestone to the organic rich Point Pleasant/Utica Shale (Smosna and Patchen, 1991). These deposits and the Reedsville Shale and Juniata Formation make up the Taconic flysch deposits (Milici,1996).

Tectonic activity slowed tremendously in the early Silurian, which allowed accommodation space to fill up. Silurian and early Devonian stratigraphy is dominated by post Taconic molasse and carbonate shelf deposits (Milici, 1996). Early Silurian deposits include; the barrier island, tidal channel and fluvial channel deposits of the Tuscarora Sandstone and Rose Hill Formation (Yeakel, 1962; Whisonant, 1977; Cotter, 1983; Milici, 1996). Accommodation 
was mostly filled by the start of the late Silurian resulting in a closed basin providing a hypersaline environment and salt precipitation within the Salina Group. Below the Salina group lies the Lockport Dolomite and above lies the Kesyer Formation (Milici, 1996). Marking the beginning of the Devonian is continued carbonate shelf and molasse sedimentation of the Helderburg Limestone, Oriskany Sandstone and Huntersville Chert (Milici, 1996).

The middle Devonian and Acadian related deposition is marked by the Tioga Ash which is located within the upper portion of the Onondaga Limestone (Hayward, 2012). The Onondaga Limestone was deposited in an open carbonate shelf setting and has been described as a "very fine grained to crystalline, light to dark brownish-gray, somewhat argillaceous and cherty limestone (Fettke, 1961).” Increased tectonic loading and foreland basin subsidence ceased Onondaga deposition and led to a rapid transgression and a new depositional regime labelled the Catskill delta. The middle Devonian to late Mississippian Catskill delta complex is a fill sequence that formed a large clastic wedge. This sequence represents an overall coarsening upward sequence that gradually becomes more non-marine (Milici, 1996). The Catskill clastic wedge consists of multiple black shale units such as the Marcellus Formation, Geneseo Formation, and extending farther west into Ohio the Middlesex, Rhinestreet, Huron, Cleveland and Sunbury formations. Interpreted as deep marine deposits within anoxic conditions, black shale units are usually organic-rich and radioactive. The Marcellus Formation is the most organic-rich shale, and is located at the base of the Catskill wedge. Other lithologies included within this delta system include gray silty shale, siltstone, fine-grained sandstone, and micritic limestone (de Witt et al., 1993). The Mahantango Formation or the subdivided Moscow, Ludlowville, and Skaneateles formations lie directly above the Marcellus Formation and normally observed as shallowing upward highstand system tract deposits. The lower 
Mahantango or Skaneateles parasequences are mudstone and siltstone dominated, while the upper Mahantango or Moscow formations are more silty shale and sand dominated. Facies include lower to upper-shelf turbidites, tidal and fluvial channels, tidal flat, point bar, and migrating shoal (Slattery, 1993). The last deposits within the middle Devonian are within the Tully Limestone. The Tully Limestone has been described as either a pure calcilutite (micrite) or a shaly calcilutite depending on the distance from the sediment source. Skeletal fossil percentages within the Tully range from 4 to 16 percent with carbonate mud percentages ranging from 49 to 77 percent and insoluble mud percentages ranging from 10 to 31 percent (Heckel, 1969).

Upper Devonian formations begin with the Geneseo Formation, which is a grey to black shale with high potential for sourcing hydrocarbons. As the Catskill delta complex continued to fill the basin, near-shore environments began to migrate westward. In Clearfield County the lower Elk Sandstone are turbidite deposits, the upper Elk and Bradford sandstone units are coarser grained nearshore deposits, and the Venango Sandstone is fluvial channel or deltaic deposits (Boswell et al., 1996a; Boswell et al., 1996b; Donaldson et al., 1996).

Lower Mississippian deposits are thin within Clearfield County, but throughout the basin they consist of the Berea, Weir and Big Injun sandstone units and represent the last sediment fill of the Acadian wedge (Kulander and Ryder, 2005).

Beginning in the late Mississippian a stable shelf formed allowing the deposition of the Greenbrier Limestone. This fossiliferous to oolitic limestone is bounded by unconformities above and below. While the Greenbrier Limestone is not present in Clearfield County it marks the beginning of Alleghenian orogenesis. The remaining Allegheny deposits are late Mississippian to Permian in age (Kulander and Ryder, 2005). Deposits include the 
Pennsylvanian Pottsville Formation, Allegheny Group, Conemaugh Group, Monongalia Group, and the Permian Dunkard Group Facies within these deposits range from terrestrial fluvial channel sandstone, flood bank shale, lacustrine shale, and shallow swamp coal (Becker et al., 2006).

\begin{tabular}{|c|c|c|c|}
\hline 299 MYA & Permian & Dunkard Group & \multirow{6}{*}{ 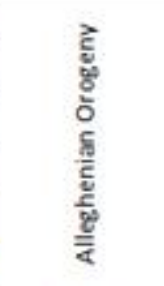 } \\
\hline \multirow[b]{4}{*}{318 MYA } & \multirow{4}{*}{ 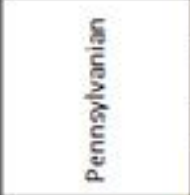 } & Monongehela Group & \\
\hline & & Conemaugh Group & \\
\hline & & Allegheny Group & \\
\hline & & Pottsville Group & \\
\hline \multirow[b]{2}{*}{359 MYA } & \multirow{2}{*}{ Mississippian } & Greenbrier Limestone & \\
\hline & & Berea/Weir/Big Injun Sandstones & \multirow{3}{*}{ 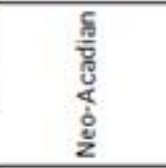 } \\
\hline \multirow[b]{12}{*}{416 MYA } & \multirow{2}{*}{$\begin{array}{c}\text { Upper } \\
\text { Devonian }\end{array}$} & Bradford and Elk Sandstones & \\
\hline & & Geneseo Shale & \\
\hline & \multirow{6}{*}{ 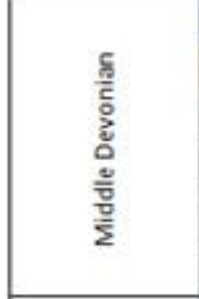 } & Tully Limestone & \multirow{6}{*}{ 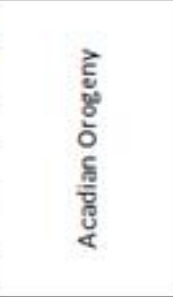 } \\
\hline & & Moscow Shale & \\
\hline & & Lundlowville Shale & \\
\hline & & Skaneateles Shale & \\
\hline & & Marcellus Formation & \\
\hline & & Tiogra Ash Bed & \\
\hline & \multirow{4}{*}{ 产 } & Onondaga Limestone & \multirow{15}{*}{ 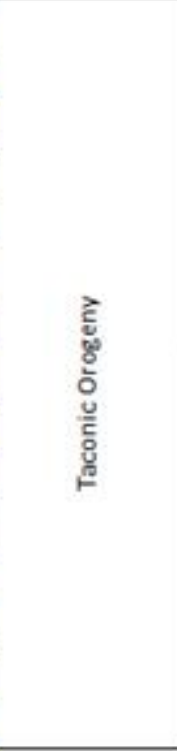 } \\
\hline & & Huntersville Chert & \\
\hline & & Oriskany Sandstone & \\
\hline & & Helderberg Group & \\
\hline \multirow[b]{5}{*}{443 MYA } & \multirow{5}{*}{$\frac{\frac{5}{5}}{\frac{5}{5}}$} & Keyser Formation & \\
\hline & & Salina Salt & \\
\hline & & Lockport Dolomite & \\
\hline & & Rose Hill Formation & \\
\hline & & Tuscarora Formation & \\
\hline \multirow[b]{6}{*}{$488 \mathrm{MYA}$} & \multirow{6}{*}{$\begin{array}{l}\frac{5}{0} \\
\frac{0}{3} \\
\frac{0}{0}\end{array}$} & Juniata formation & \\
\hline & & Reedsville Shale & \\
\hline & & Utica/Point Pleasant Formation & \\
\hline & & Trenton / Black River Limestones & \\
\hline & & Wells Creek Dolomite & \\
\hline & & Beekmantown Group & \\
\hline \multirow[b]{4}{*}{520 MYA } & \multirow{4}{*}{$\frac{\text { ह }}{\frac{\mathrm{g}}{\tilde{E}}}$} & Rose Run Sandstone & \multirow{2}{*}{$\begin{array}{c}\text { Rome Trough } \\
\text { extension }\end{array}$} \\
\hline & & Copper Ridge Dolomite & \\
\hline & & Conassauga Shale & \multirow{2}{*}{ Passive Margin } \\
\hline & & Rome formation & \\
\hline
\end{tabular}

Figure 6. Central Pennsylvania stratigraphy with the formation of interest highlighted in red; ages are mostly Upper Silurian to Middle Devonian. Modified from (King, 2014). 


\subsection{Regional Structural Geology}

The Allegheny orogeny is responsible for the present deformed state of the Marcellus Formation and related strata. Some of the structures resulted from this thin-skinned tectonic episode include large scale detachment faults (Evans, 1994, Kulander and Ryder, 2005).

Detachments in the Valley and Ridge are predominately in Cambrian shale, while detachments in the Appalachian Plateau are predominately in the Reedsville Shale or the multiple salt units of the Salina Group (Evans, 1994, Kulander and Ryder, 2005). Detachment faulting within the Appalachian Plateau extends up from the basal detachment and displaces strata by westward verging thrust or eastward verging back thrust (Figure 7) (Scanlin and Engelder, 2005).

Imbricated thrusts and back thrusts are seen at the core of the Chestnut Ridge anticline (Figures 4 and 7). Three zones have been recognized across the Chestnut Ridge anticline and include the salt detachment zone, the fault imbrication zone, and the wedge zone. The wedge zone provides the broad kilometer scale anticline (Scanlin and Engelder, 2005).

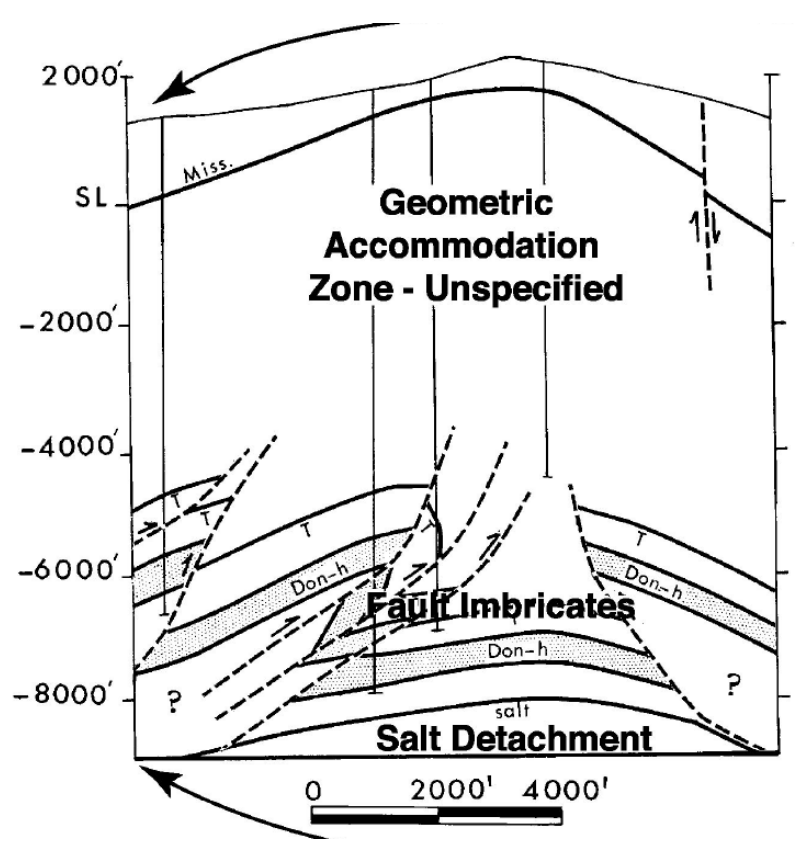

Figure 7. Cross section of imbricate thrust and back thrust faulting in the core of the Chestnut Ridge anticline in the Appalachian basin (Scanlin and Engelder, 2005). 
Shortening within the Appalachian Plateau has also been attributed to accommodation by folding (Gillespie et., 2013). Kink band folding is produced when layer parallel shortening causes flexural slip between anisotropic sedimentary layers. Strain is focused within thin, weak, and usually shale dominated lithologies allowing the thicker, stronger, sandstone and limestone lithologies to maintain thickness and produce parallel fold geometry (Fossen, 2010). Kink band folds have been observed at the surface in the Valley and Ridge province from the centimeter to kilometer scale (Faill, 1969; Fail, 1973). Kink bands formation in the subsurface usually requires a basal detachment and roof detachment. Many subsurface kink bands in the Appalachian basin have a basal detachment in Salina Group and a roof detachment within the Moscow Formation (Gillespie et al., 2013) (Figure 8).

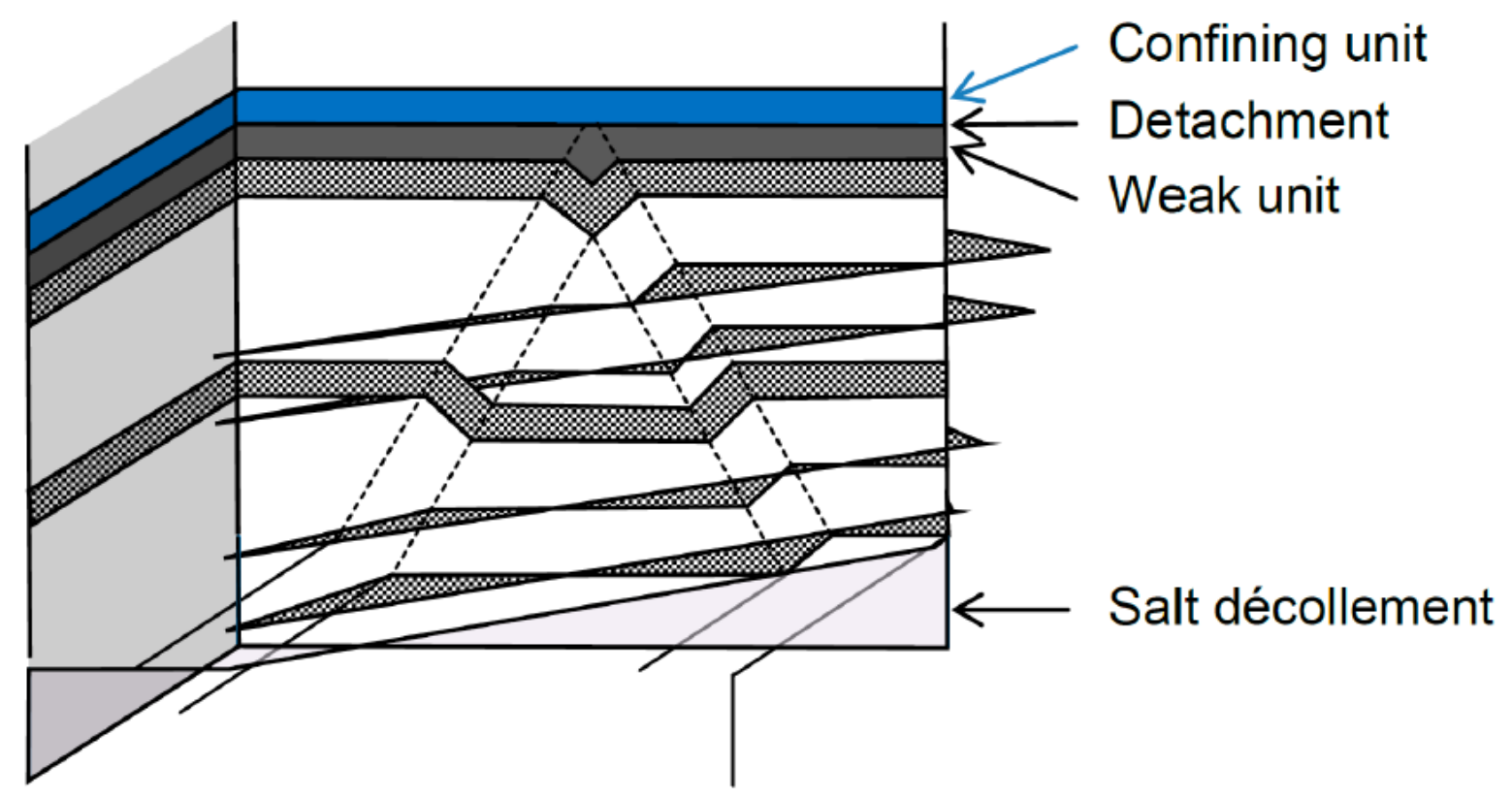

Figure 8. Model for kink band structures within the Appalachian Plateau (Gillespie et al., 2013). 
Clearfield County lies within the Appalachian Plateau and is uniquely located at the curve of the Valley and Ridge province (Figure 3). Within the bend of the Pennsylvania salient in the Appalachian Plateau numerous oblique strike-slip fault geometries have been recognized (Faill et al., 1989) (Figure 9). One interpretation for oblique strike-slip development relies on a two dimensional thrust stress regime (maximum compressive stress perpendicular to strike and minimum horizontal stress parallel to strike) where shortening is accommodated in three ways: extensional faulting in the minimum stress direction, folding in the maximum stress direction, and thrust faulting in the maximum stress direction. This interpretation is also reliant on two stage development. The extensional faults were formed first and later oblique strike-slip faulting occurred along the same planes (Faill et al., 1989) (Figure 10).

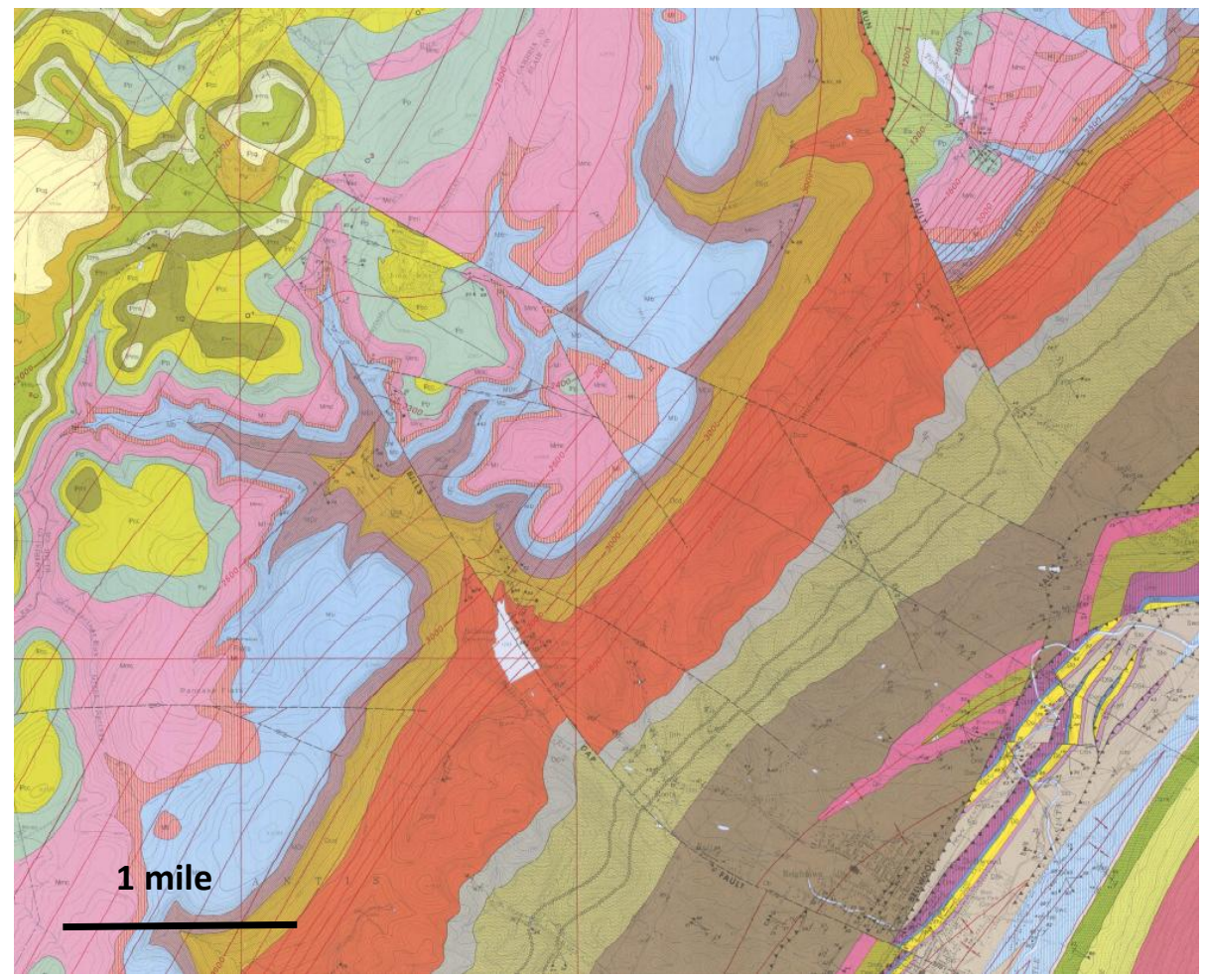

Figure 9. Three miles south of Clearfield County showing the triangular nature of cross-strike, strike-slip structures (Faill et al., 1989). 

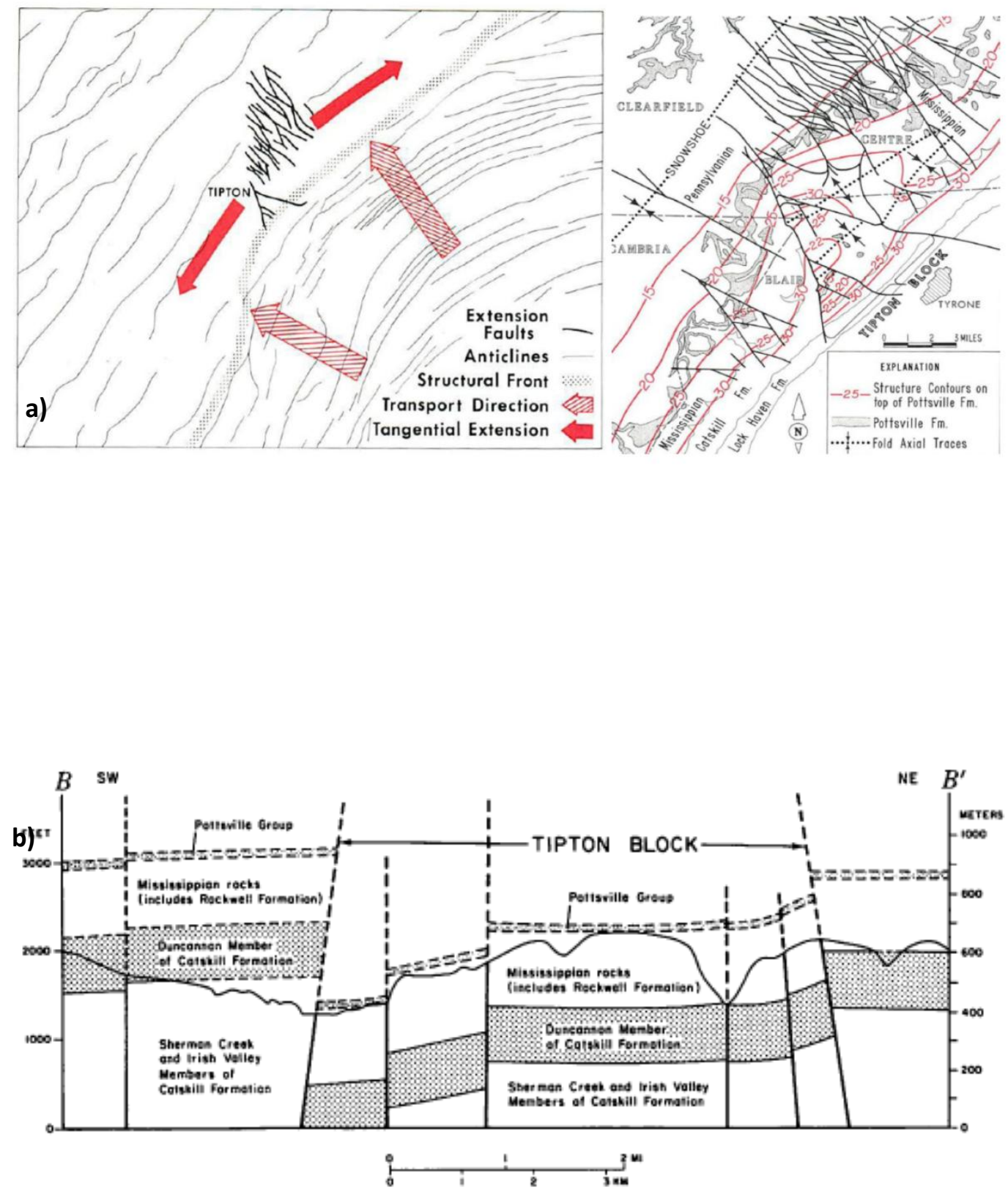

Figure 10. a) Map view of strike-slip clusters in Clearfield County, Pennsylvania (Faill et al.,1989). b) Cross section through the strike-slip structures in Clearfield County, Pennsylvania (Faill et al.,1989). 
Another interpretation is that oblique strike-slip development resulted from paleojoints.

Perhaps present day joint orientations reflect the same orientations of the present day oblique strike-slip faults in Clearfield County (Zhao and Jacobi, 1997). These joints are interpreted to have developed in three deformation stages and the two stages most prominent in Clearfield County are stages one and three (Figure 11). En echelon regional cross-fold joints in these orientations could potentially connect during later deformation stages resulting in oblique-strikeslip faulting.

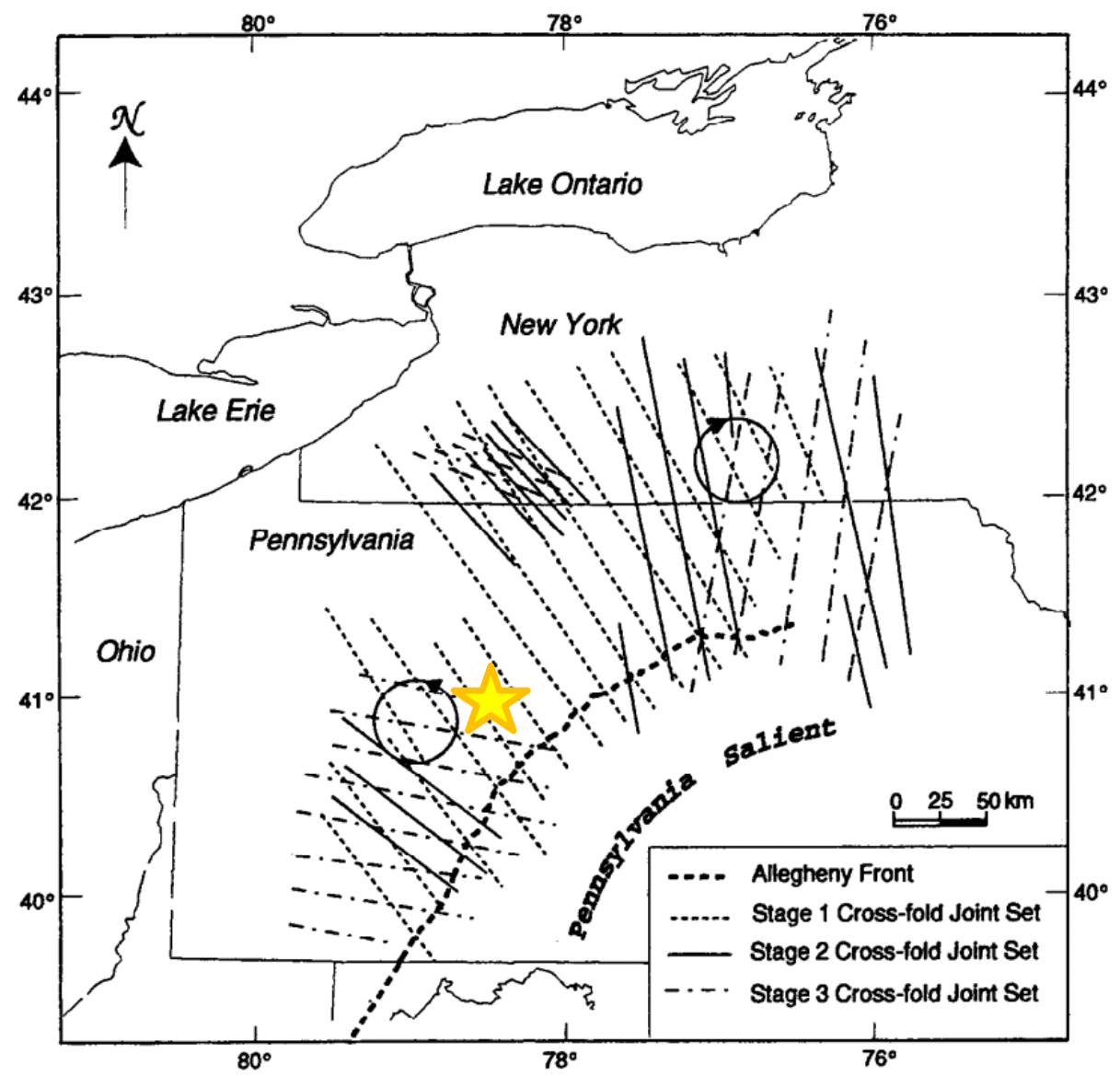

Figure 11. Cross fold joint development in the Appalachian Plateau. Yellow star indicates Clearfield County; notice the acute angle between stage one and three joint sets (Zhao and Jacobi, 1997). 


\section{Previous Work/Review}

The first portion of this section will acknowledge the geologic factors affecting production, which are not the main focus of this research (factors $1-8$, page 6). The Marcellus Formation in Clearfield County shows comparable depth, pressure gradient, thickness, total organic carbon, and thermal maturity (factors 1-5) as the two core drilling areas in southwestern and northeastern Pennsylvania (Zagorski et al., 2012; Boyce, 2010; Yanni, 2010). The depth of the Marcellus Formation is around 7,000 to 8,000 feet (2130 to $2440 \mathrm{~m}$ ) in Clearfield County, which is comparable to the higher productive areas in southwest and northeast Pennsylvania (Zagorski et al., 2012) (Figure12). The reported pressure gradient within Clearfield County ranges from 0.5 to $0.525 \mathrm{psi} / \mathrm{ft}$ and is comparable to southwestern and northeastern Pennsylvania, which ranges from 0.45 to $0.525 \mathrm{psi} / \mathrm{ft}$ (Figure 13) (Zagorski et al., 2012). However, there is no clear standard for pressure gradient determination. Pressure gradient determination has a lot of variables involved and values can reach as high as $0.7 \mathrm{psi} / \mathrm{ft}$ (personal communication with Peter Sullivan, Energy Corporation of America). The Marcellus thickness in Clearfield County ranges from 100 to 200 feet (30-60 m), which is comparable to southwest Pennsylvania, but not northeast Pennsylvania (Figure 14). Lower thickness of the Marcellus usually corresponds to slower sedimentary rates and increased organic matter preservation. Marcellus thickness is greater in northeast Pennsylvania and likely experienced faster sedimentary rates and organic dilution from increased detrital input (Zagorski et al., 2012). Total organic carbon percentages in northern Clearfield County are comparable to the highly productive Greene and Washington counties of southwest Pennsylvania. By modeling total organic carbon from uranium percentages (Boyce, 2010; Yanni, 2010) show that northern Clearfield County, Washington County, and Greene County have approximately 90 feet (27meters) of organic shale with seven 
percent of total organic carbon (Figures 15 and 16). By burying and pressurizing the Marcellus at significant depth the organic material is converted into oil, natural gas liquids, and natural gas. There is a direct relationship of vitrinite reflectance to hydrocarbon maturity, which has been mapped extensively throughout the basin (Zagorski et al., 2012). The thermal maturity ranges between 1.5 and 2.0 Ro within Clearfield County identical to Greene and parts of Washington county (Zagorski et al., 2012) (Figure 17). Basin wide studies of porosity in the Marcellus Formation indicate that the main type of porosity is formed from the maturation of organic material.

Porosity and permeability (factor 6) have not been mapped at a basin scale at this time. However, porosity types and porosity effects on permeability for the Marcellus Formation have been studied intensely (Prince et al., 2011; Loucks et al., 2012). Four different types of porosity within the Marcellus Formation and many other organic-rich mudstones have been recognized include; interpartical, intrapartical, organic matter and fracture porosity. Interpartical porosity is open pore space between particles. Intrapartical porosity is open pore space within the particles. Organic-matter pores are within organic material and are formed during the maturation of hydrocarbons. Fracture pores occur during thermal cracking caused by increased fluid and gas pressures overcoming the least compressive stress $\left(\widetilde{O}_{\min }\right)$ (Loucks et al., 2012). Many of the micro-fractures are healed with calcite but have porosity within them and some micro-fractures are open. In situ permeability is entirely dependent on the size and frequency of the various pores within the reservoir (Loucks et al., 2012). For example, a positive power law relationship in the Marcellus Formation exists between core derived total porosity and core derived matrix permeability (Prince et al., 2011). 
Gas saturation or gas in place (factor 7) is ultimately controlled by the amount of maturation of source rock (amount of organic material converted to gas) and the porosity of the shale, where the gas is contained. However, gas saturation does not solely control production potential because primary migration out of the Marcellus can occur. Also, to extract the gas in place hydraulic fracturing is required. Taking these factors into account it is difficult to map gas saturation on a basin scale. However, gas saturation from well logs can be estimated using multiple equations including the Archie equation, the modified Archie equation, the Simandoux equation, and the modified Simandoux equation. These equations are controlled by Archie constants, resistivity of water, resistivity of the formation, porosity, volume of shale from gamma-ray logs, and volume of Uranium from spectral gamma-ray logs (Boyce, 2010).

Lithology and mineralogy (factor 8) within the Appalachian basin has been modeled using neural network methods and indicates that Clearfield County has increased organiclithofacies thickness, but decreased brittle facies thickness in comparison to other areas in the basin (Figure 18) (Wang, 2012). Increased organic-lithofacies thickness within the Marcellus can potentially increase production potential while decreased brittle-lithofacies can potentially decrease production potential.

Structural complexity, natural fracturing, and rock mechanics are the focus of this research and previous work also exists on this subject. Structural complexity and natural fracturing has been interpreted using a seismic attribute analysis (curvature, variance, and ant tracking) for the 3D seismic volume used in this study (Roberts, 2013). Roberts states "fracture swarms and fault damage zones may surround many of the major seismic attribute interpreted faults, increasing the risk of fluid migration and/or redirection of hydraulic stimulation energy away from wells." 
Outcrop studies and subsurface Formation-Micro-Imager (FMI) log evaluation has uncovered systematic natural fracture development in the Marcellus Formation recognized as the northeast trending $\mathrm{J} 1$ and northwest trending $\mathrm{J} 2$ joint sets. These joint sets were observed by a FMI log in a well near to the 3D seismic data set (Engelder et al., 2009; Roberts, 2013).

Geomechanical properties can be measured or calculated at many scales such as core plugs, well logs, and seismic data. Rock mechanics have played a large role in reservoir characterization (Gray et al., 2012; Chaveste et al., 2013; Eshkalak et al., 2013; Chopra et al., 2014). Brittleness is controlled by mineralogy; however it can be defined by Young's Modulus and Poison's ratio as well (Rickman et al., 2008). This relationship allows for larger scale geomechanical models with well logs and pre-stack seismic data which can used to examine reservoir potential (Gray et al., 2012; Eshalak et al., 2013; Chopra et al., 2014). 


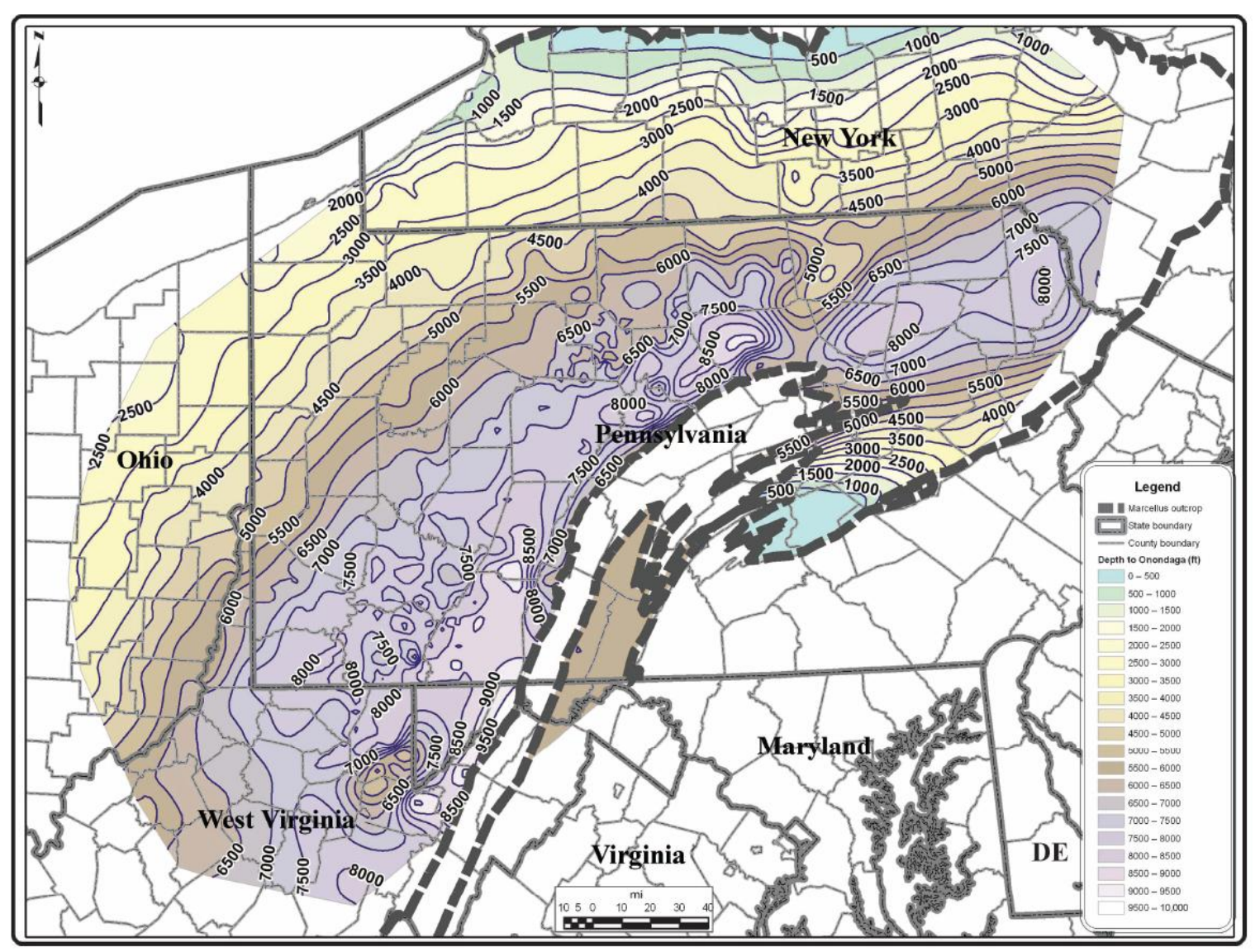

Figure 12. Onondaga structure map showing the similar depth range in Clearfield County Pennsylvania (green box) compared to the highly productive and targeted areas in southwest Pennsylvania and northwest Pennsylvania (Zagorski et al., 2012). 


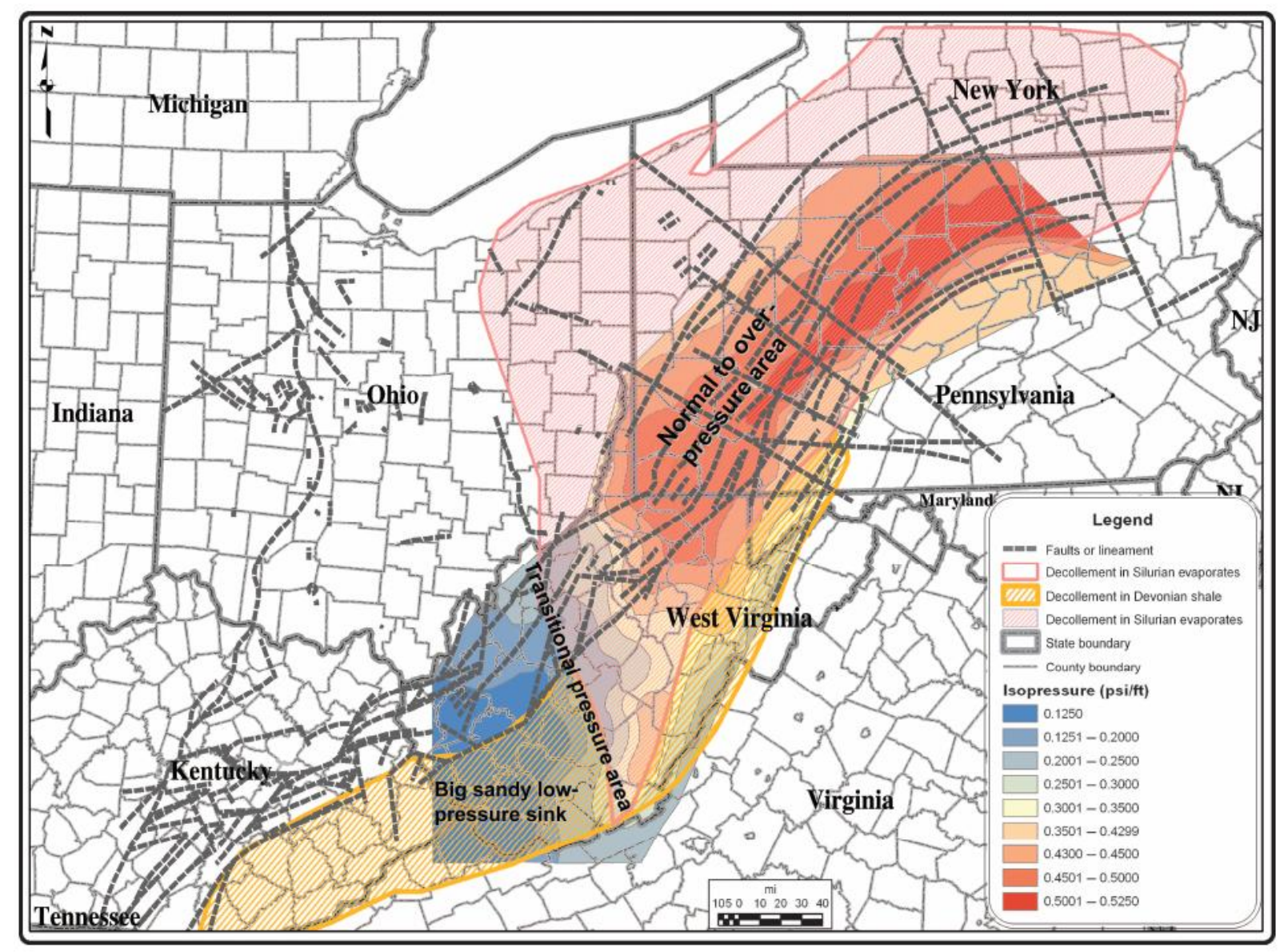

Figure 13. Pressure gradient map within the Appalachian Basin. The Marcellus is under normal to over-pressured conditions in most of Pennsylvania (Zagorski et al., 2012). 


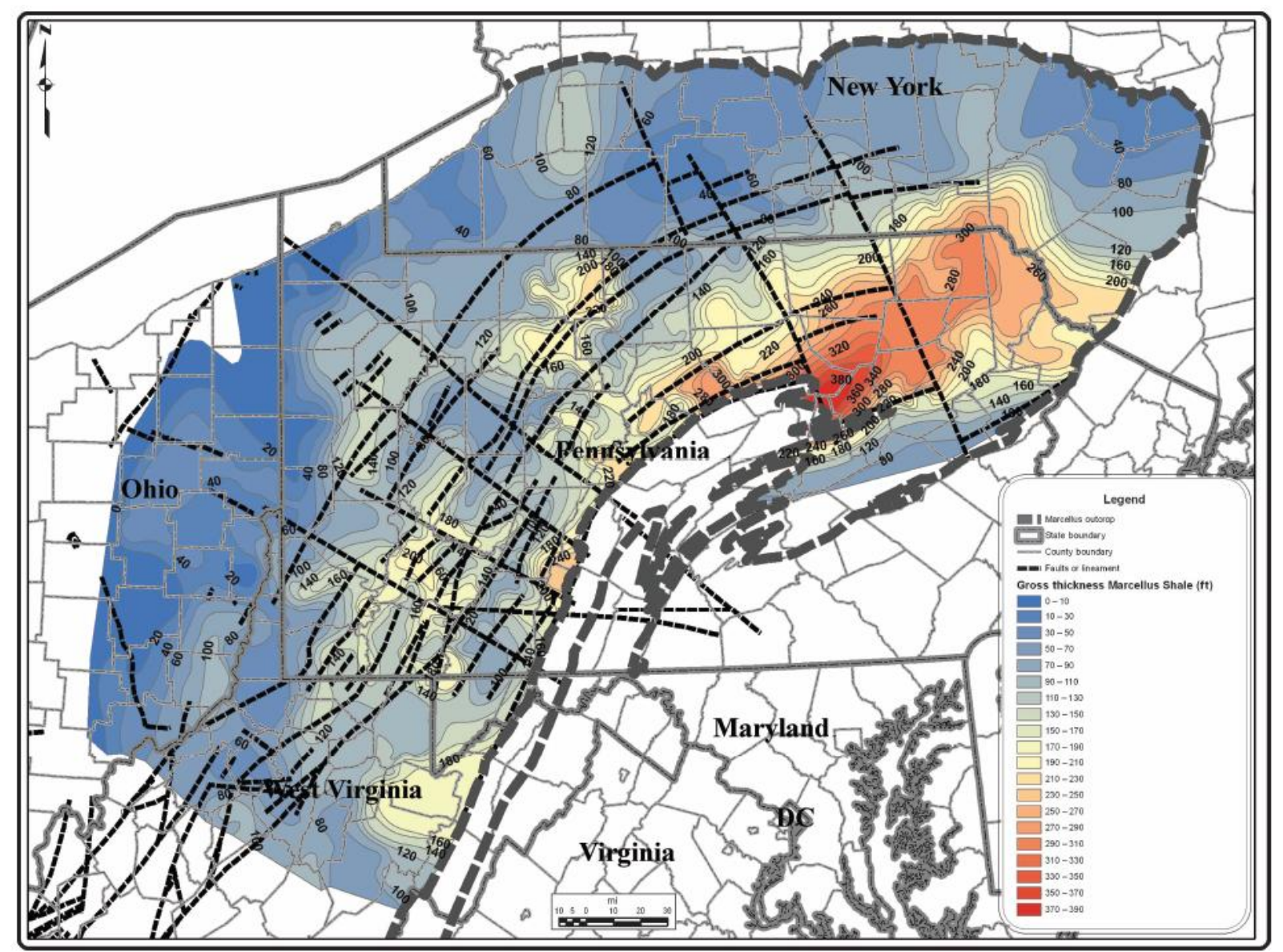

Figure 14. Marcellus thickness map with interpreted faults or lineaments showing similar thickness trends in Clearfield County as southwest Pennsylvania (Zagorski et al., 2012). 


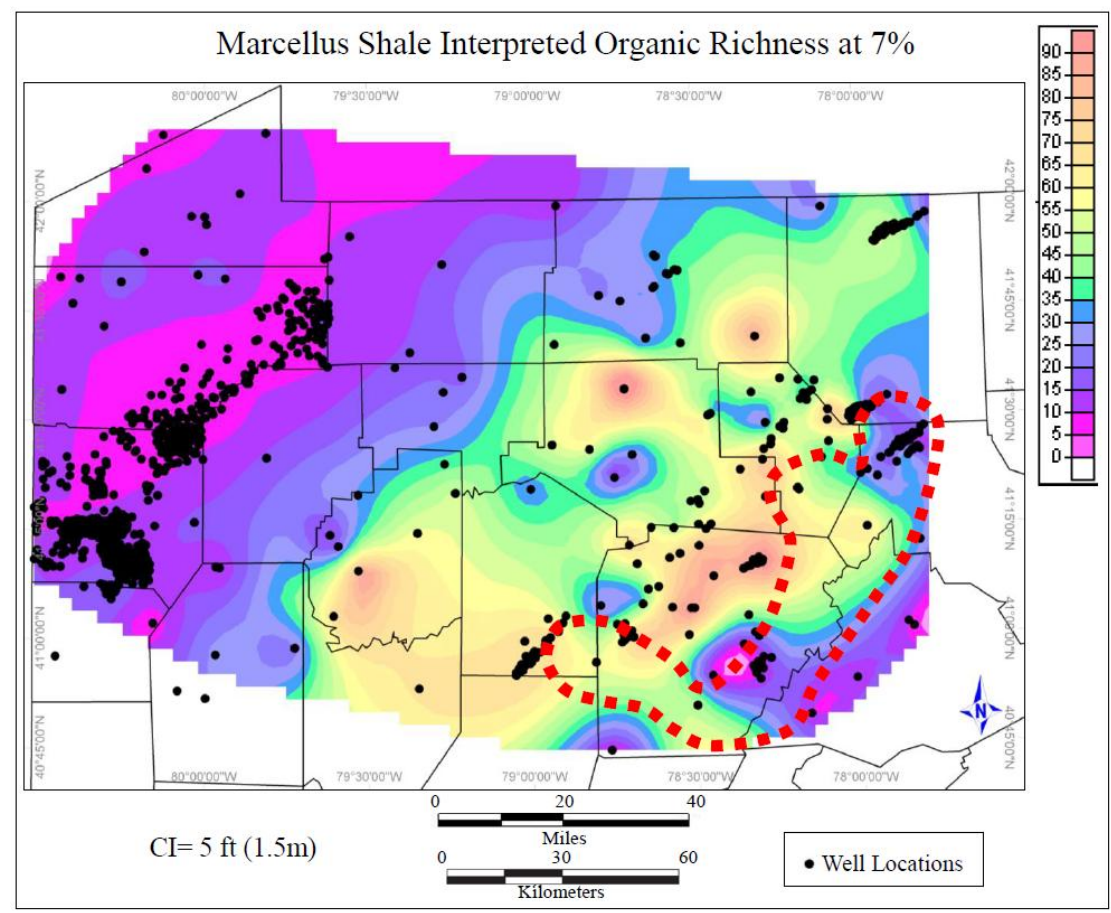

Figure 15. Net thickness of organic shale containing seven percent organic carbon. Northern Clearfield County shows 90 feet of net thickness. The red outline marks the thickest region of the Marcellus (Yanni, 2010).

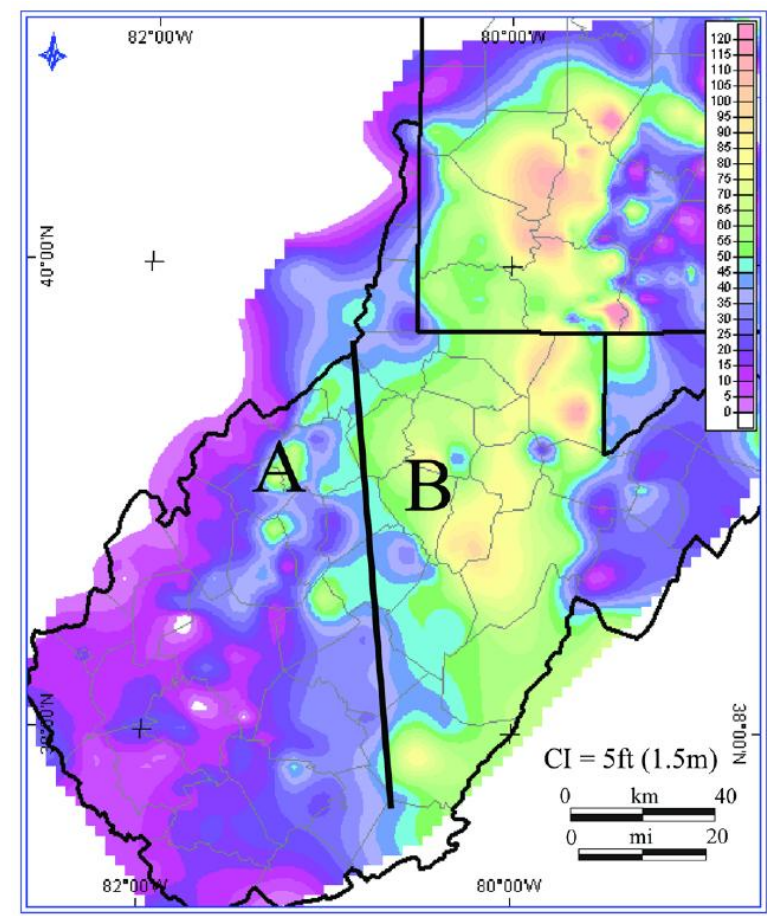

Figure 16. Net thickness of organic shale containing seven percent organic carbon. Greene and Washington Counties show approximately 90 feet of net thickness. Notice the scale change (Boyce, 2010). 


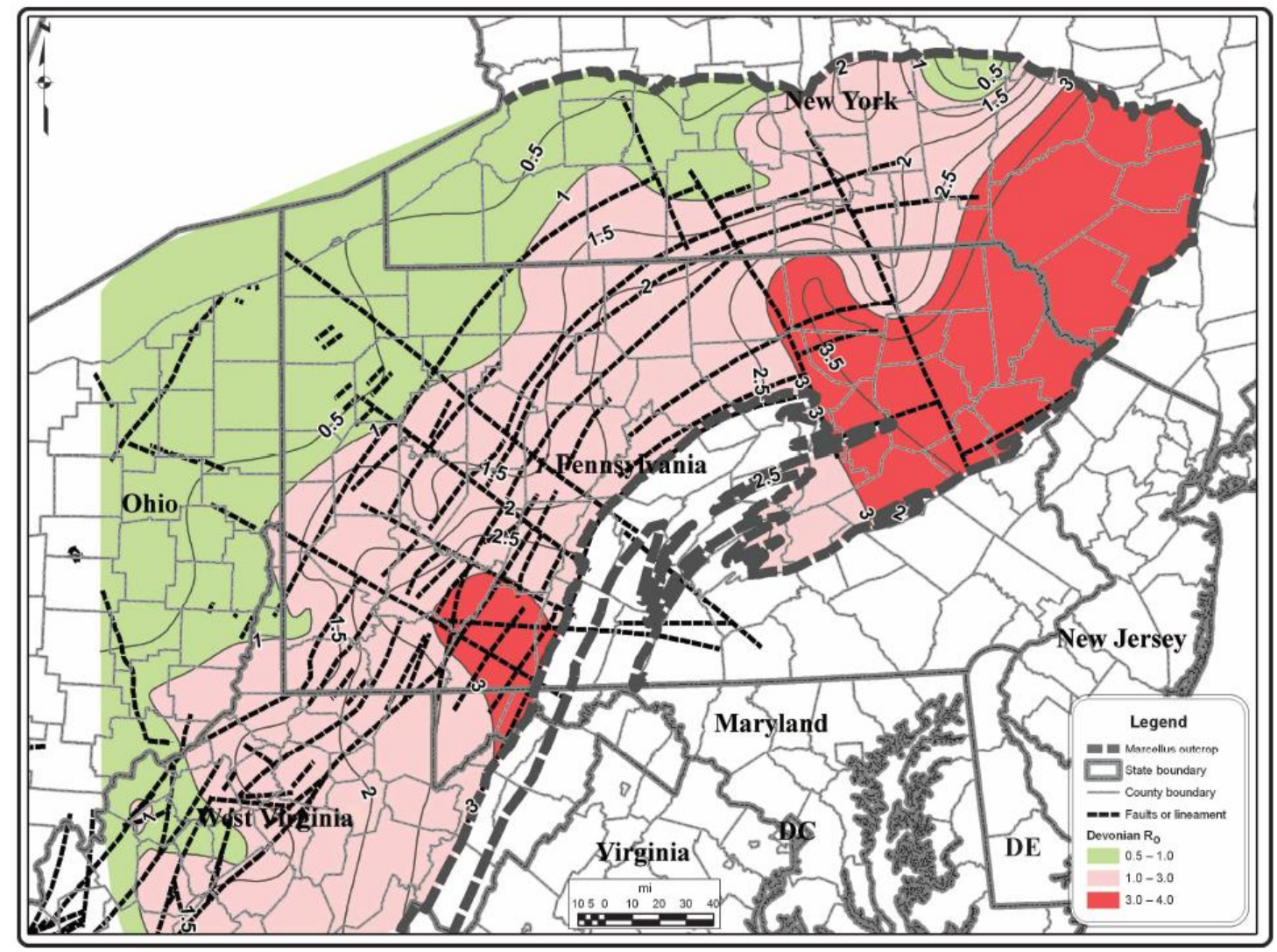

Figure 17. Thermal maturity map of the Marcellus Formation within the Appalachian basin. Clearfield County ranges from 1.5 to 2.0 Ro (Zagorski et al., 2012).

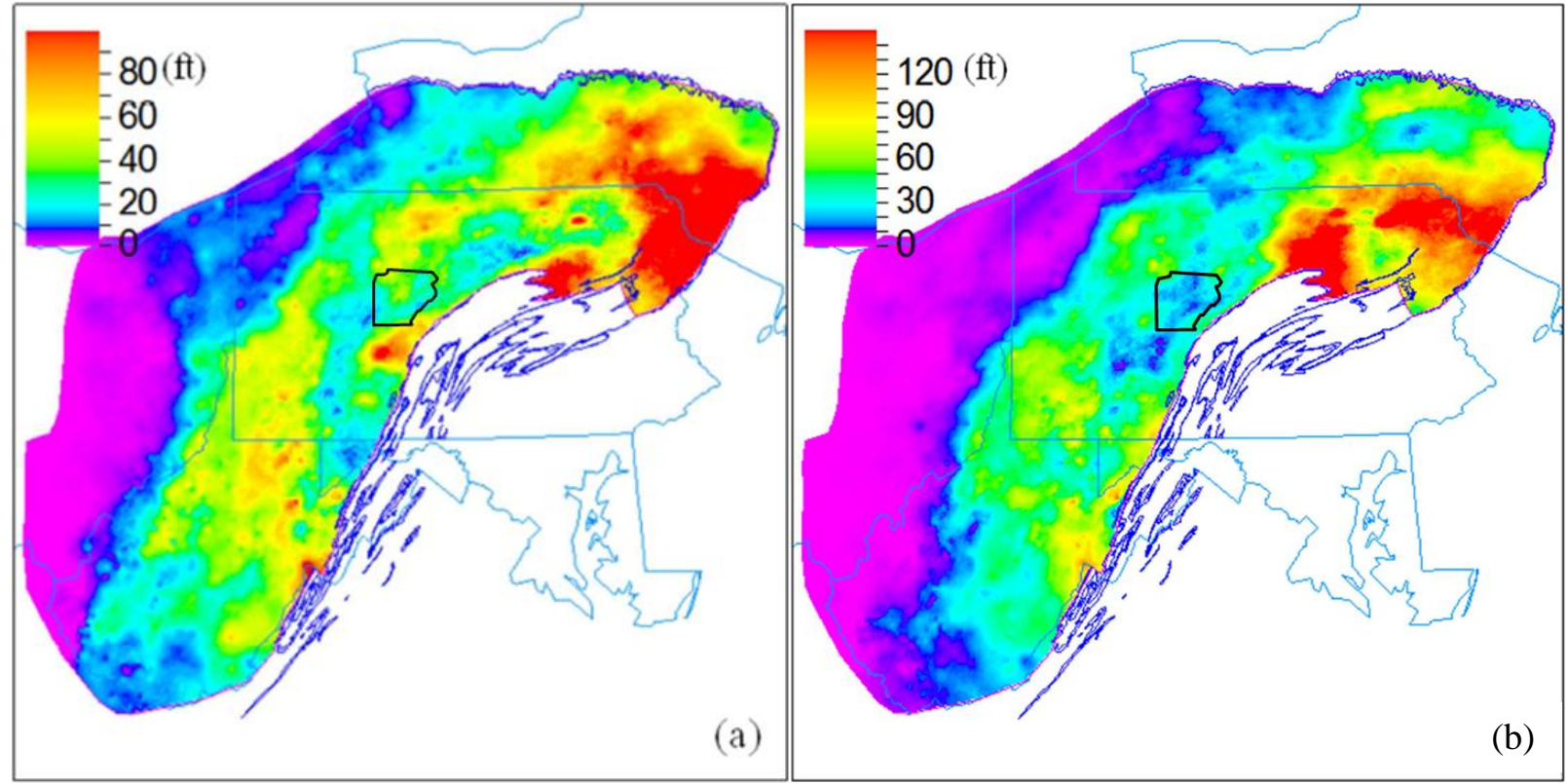

Figure 18. (a) Neural network solution for all organic facies thickness. (b) Neural network for all brittle facies thickness (Wang, 2012). 


\section{Data Set and Methodology}

The available data across the study area in Clearfield County, Pennsylvania consists of post-stack 3D seismic, digital and raster well logs, a microseismic survey and well completion and stimulation reports.

The methods used to evaluate how structural complexity, natural fracturing, and rock mechanics are effecting hydraulic stimulation and gas production are highlighted in greater detail in the subsequent chapters. Chapter 6 (Fault Modeling) covers the structural complexity factor of the study area by correlating well logs, generating a synthetic seismogram, converting the post-stack 3D seismic to depth with a velocity model, and using the horizon and fault modeling algorithms included in Petrel ${ }^{\mathrm{TM}}$ software. Chapter $7 \& 8$ (Geomechanical Modeling and Microseismic) covers the natural fracturing factor by using a mass spring algorithm to restore the horizons and solve for principle strain magnitudes, which are evaluated in a geocellular model (Midland Valley Move ${ }^{\mathrm{TM}}$ ). The geocellular model highlights areas prone to increased fracture intensity which is compared to microseismicity and gas production. Chapter 9 (Rock Mechanics) covers the rock mechanics factor by analysis of triaxial strain testing of core samples and generation of rock properties from advanced well logs. All rock mechanic observations are tied to microseismicity, fault models and the geomechanical model. 


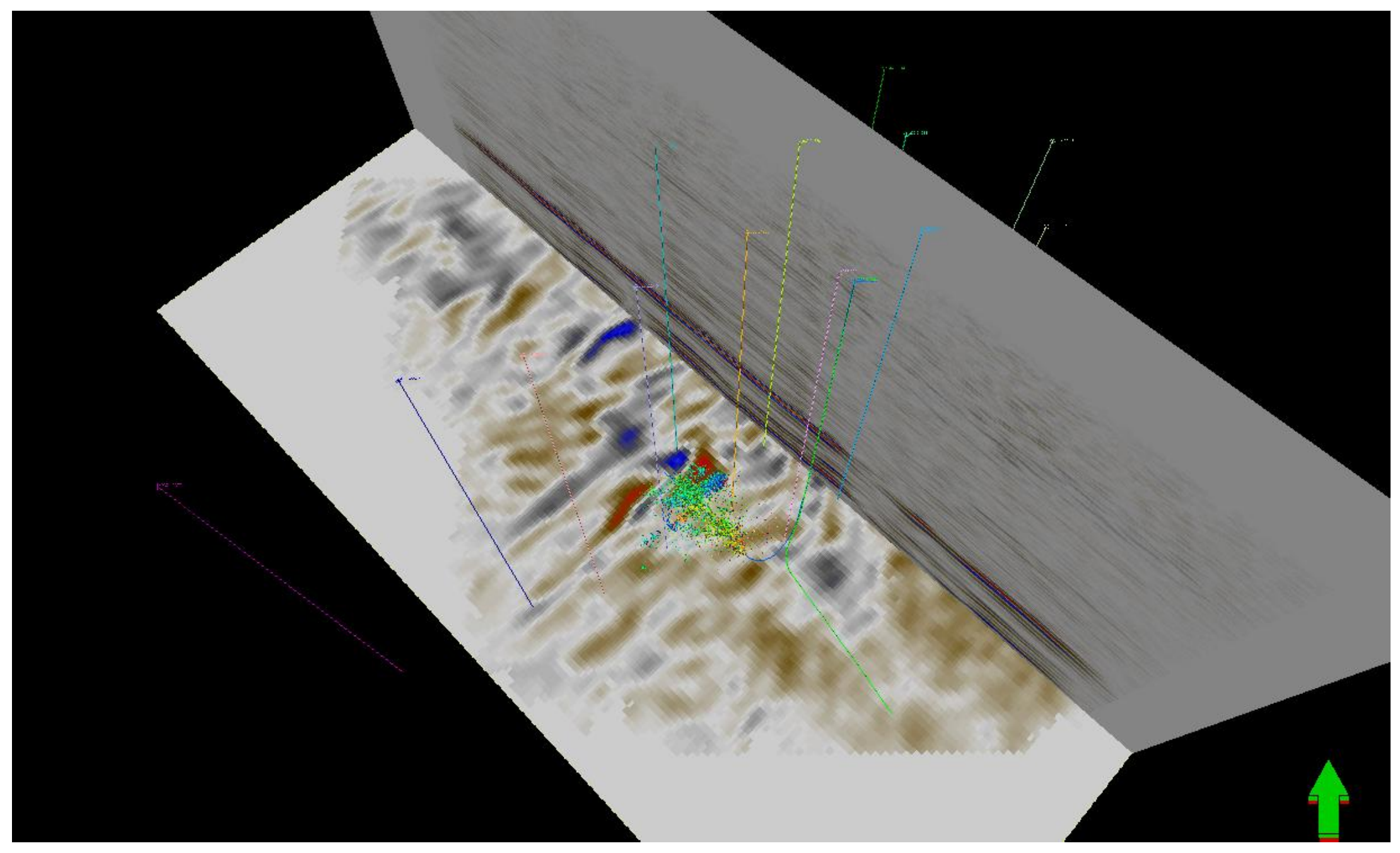

Figure 19. The data set used for this research includes a post-stack 3D seismic survey, multiple wells some with advanced wireline logs, and microseismic survey. 


\section{Fault Modeling}

\subsection{Methodology}

Depth conversion is completed in a three-step process. First, gamma-ray logs are used for mapping formation tops. Second, sonic and density well logs are used to produce a synthetic seismogram. Third, the data extracted from the synthetic seismogram and the formation types are used to produce a velocity model across the 3-D seismic survey.

Formation top picking was completed using conventional gamma-ray log picking. Certain lithologies respond differently to the gamma-ray log according the formation's clay percentage and organic material percentage. For example, the Marcellus and Geneseo have anomalously high gamma ray values (200-450 API) because they consist of approximately 5 10\% TOC and associated Uranium, while the Skaneateles, Ludlowville, and Moscow have moderately high gamma-ray values (100-150 API) because they contain approximately $2 \%$ TOC. The Onondaga and Tully limestone units are easily identifiable by sharp contact and 30 -100 API gamma-ray values. The Sixth Elk was defined by a subtle decrease in gamma-ray (90-120 API) and increase in density porosity.

Synthetic seismogram generation is based on the same concepts as normal seismic data. Seismic data generation is based on three concepts:

1. Acoustic impedance is the product of velocity and the density of a layer:

$$
Z=V \rho
$$

2. Reflectivity is calculated from acoustic impedances of two different layers:

$$
R=\frac{\left(\rho_{2} V_{2}-\rho_{1} V_{1}\right)}{\left(\rho_{2} V_{2}+\rho_{1} V_{1}\right)},
$$

3. The reflectivity values are then convolved with a wavelet to produce seismic data (Figure 20). 


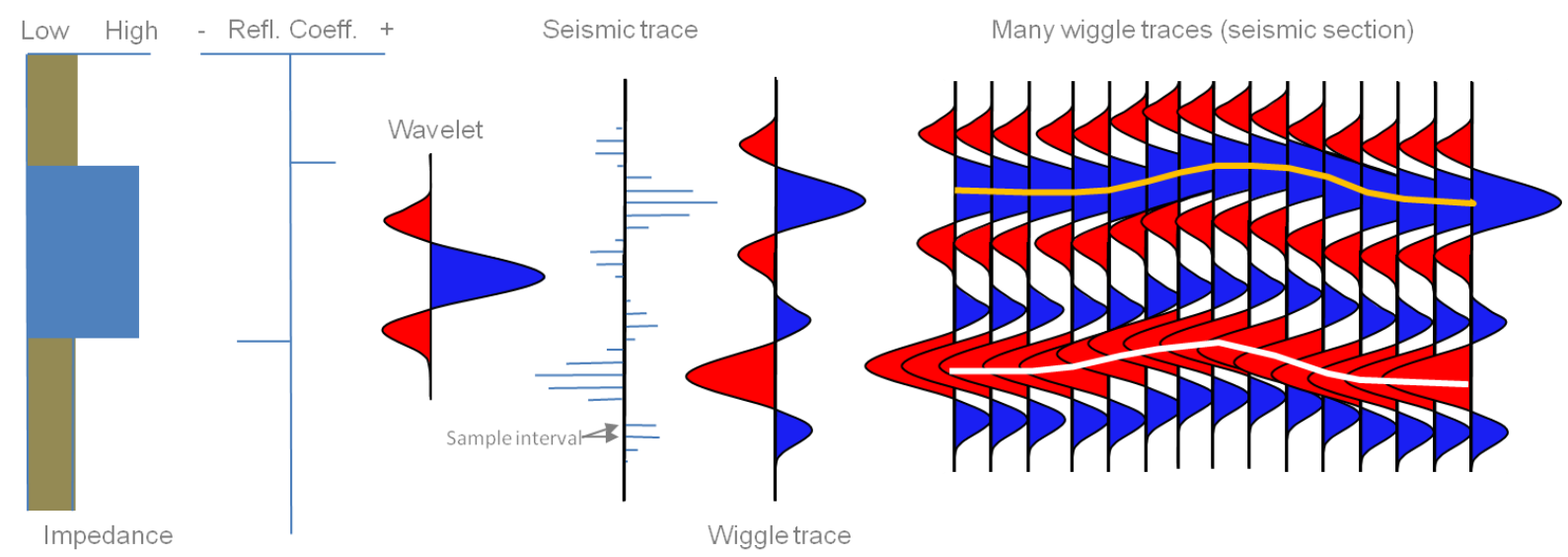

Figure 20. Diagram showing how seismic data is based on the velocity and density of layers (acoustic impedance) and then the reflectivity between layers and the wavelet convulsion process to produce a seismic trace.

Similarly, synthetic seismograms use sonic and density log data to produce acoustic impedance values, which can then be used to produce reflectivity values. The reflectivity values are convolved with an extracted wavelet to produce a synthetic seismogram. This allows for a tie between time seismic data and depth domain well logs.

To convert the 3-D seismic data into depth a velocity model is generated. First, we generated a synthetic seismogram to allow correlation of stratigraphic interpretations measured in depth to the time domain. Velocity model generation can be completed by using the stratigraphic surfaces generated in the time domain and the computed velocities between stratigraphic surfaces (Figures 21 and 22).

After the synthetic seismogram is produced, a more accurate interpretation of specific stratigraphy within 3-D volume can be made in the time domain. Initial fault analysis in the time domain can be assisted by seismic attributes such as curvature, variance, and ant tracking (covered in detail by Roberts, 2013). Seismic attribute analysis provides a quick analysis of possible fault locations based on discontinuities between traces while ignoring geometric 
constrains on structure. Also, fault modeling and geomechanical modeling is completed in the depth domain limiting the use of the faults and folds interpreted from seismic attributes.
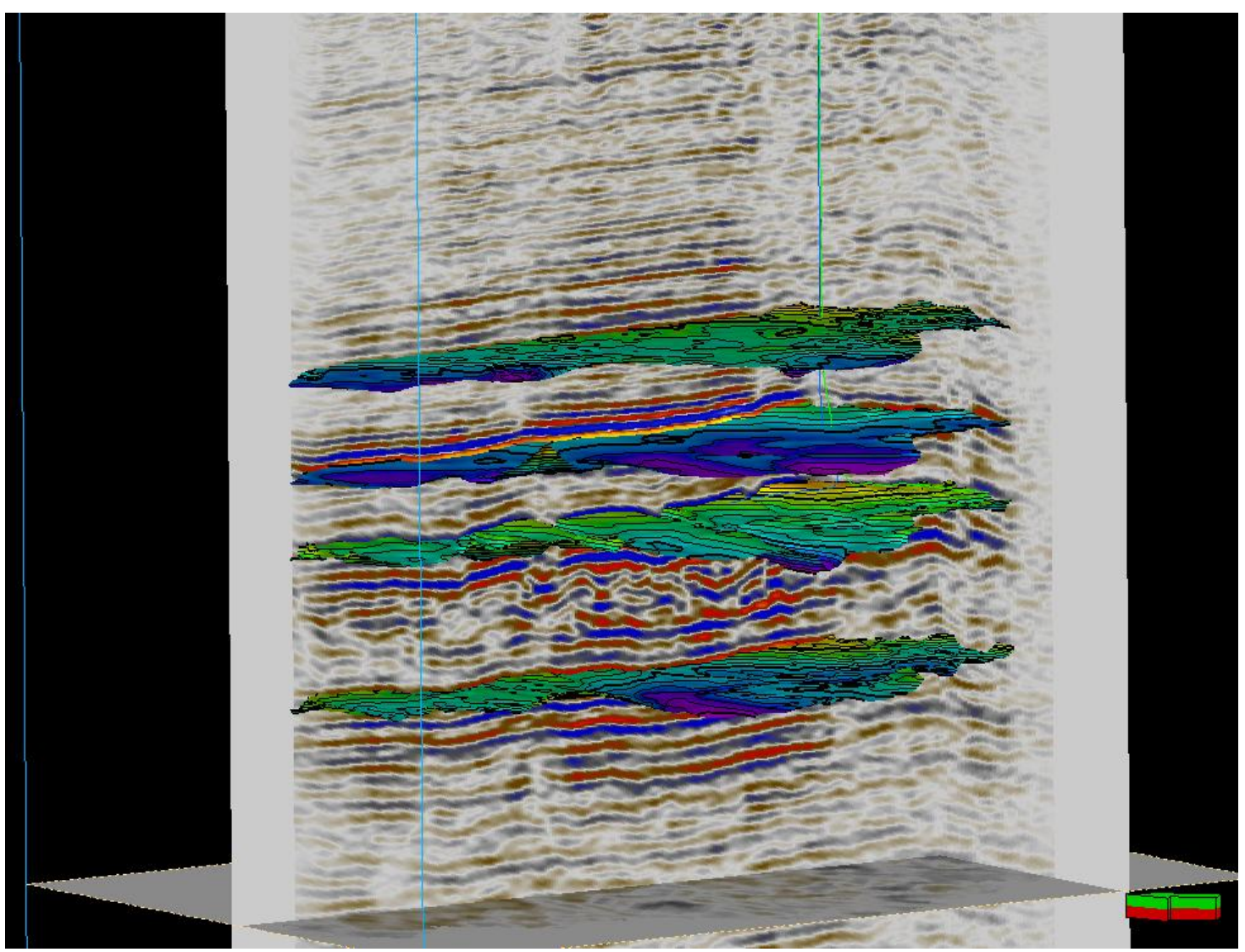

Figure 21. Surfaces used for the velocity model. They include the sixth Elk sandstone/siltstone, Tully Limestone, Onondaga Limestone, and Rose Hill Sandstone.

\begin{tabular}{|c|c|c|c|c|c|c|c|c|c|}
\hline & \multicolumn{3}{|c|}{ Base } & \multicolumn{3}{|c|}{ Correction } & \multicolumn{3}{|c|}{ Model } \\
\hline$\cong$ & Constant & & -1 & None & & & $\mathrm{V}=\mathrm{V} 0=\mathrm{V} / \mathrm{nt}$ & V0: Constant & 15200 \\
\hline 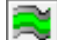 & Surface & $\Leftrightarrow$ & 曲 Elk/Bria & Well tops & $\Rightarrow$ & Elk (We & $\mathrm{V}=\mathrm{V} 0=\mathrm{V} / \mathrm{lnt}$ & VO: Constant & 14308 \\
\hline 政 & Surface & $\Rightarrow$ & 埇 Tully 2 & Well tops & $\Rightarrow$ & Pully ( & $\mathrm{V}=\mathrm{V} 0=\mathrm{V} / \mathrm{nt}$ & V0: Constant & 12600 \\
\hline 天 & Surface & $\Leftrightarrow$ & 电 Ononda & Well tops & $\Rightarrow$ & Sononda & $\mathrm{V}=\mathrm{V} 0=\mathrm{V} / \mathrm{nt}$ & V0: Constant & 15600 \\
\hline 语 & Surface & $\Rightarrow$ & Rose $\mathrm{Hi}$ & None & & & $\mathrm{V}=\mathrm{V} 0=\mathrm{V} / \mathrm{nt}$ & V0: Constant & 15000 \\
\hline$\approx$ & Constant & & -5000 & None & & & $\mathrm{V}=\mathrm{V} 0=\mathrm{V} / \mathrm{nt}$ & V0: Constant & 16000 \\
\hline
\end{tabular}

Figure 22. Parameters for the velocity model and depth conversion of the post-stack 3D seismic. (Results shown in the results section). 
After depth conversion two fault models were tested according to balanced geometry. The first model consisted of low displacement imbricated thrusts with thrust and back thrust triangle zones similar to the interpretation by Scanlin and Engelder (2005) (Figure 7). The second model consisted of standalone and conjugate pair kink band structures resembling the interpretation by Gillespie et al., (2013) (Figure 8). Both models used the oblique strike-slip faulting model similar to the model proposed at the Tipton block near southeast Clearfield County (Faill et al.,1989) (Figures 9 and 10).

In order to observe fault cuts within certain horizons, a specific workflow in Petrel ${ }^{\mathrm{TM}}$ software using fault modeling and horizon modeling was defined (Figure 23). The first round of stratigraphic surface picking is not the final stratigraphic surfaces used for horizon modeling, however it does allow for better constrained fault picks. After manual fault picking the fault interpretations are then converted into smoothed fault surfaces in the fault modeling process. In order to have better outcome from the horizon modeling algorithm it is necessary to tidy up the stratigraphic surfaces in relation to the smoothed fault surfaces. Horizon modeling then takes the once continuous stratigraphic surfaces and produces a horizon with fault cuts within it. Quality control of fault cuts is analyzed to insure displacements in the fault cuts represent reasonable offsets according to the depth converted seismic. Also, thickening and thinning of layers are interpreted within a reasonable geologic context. 


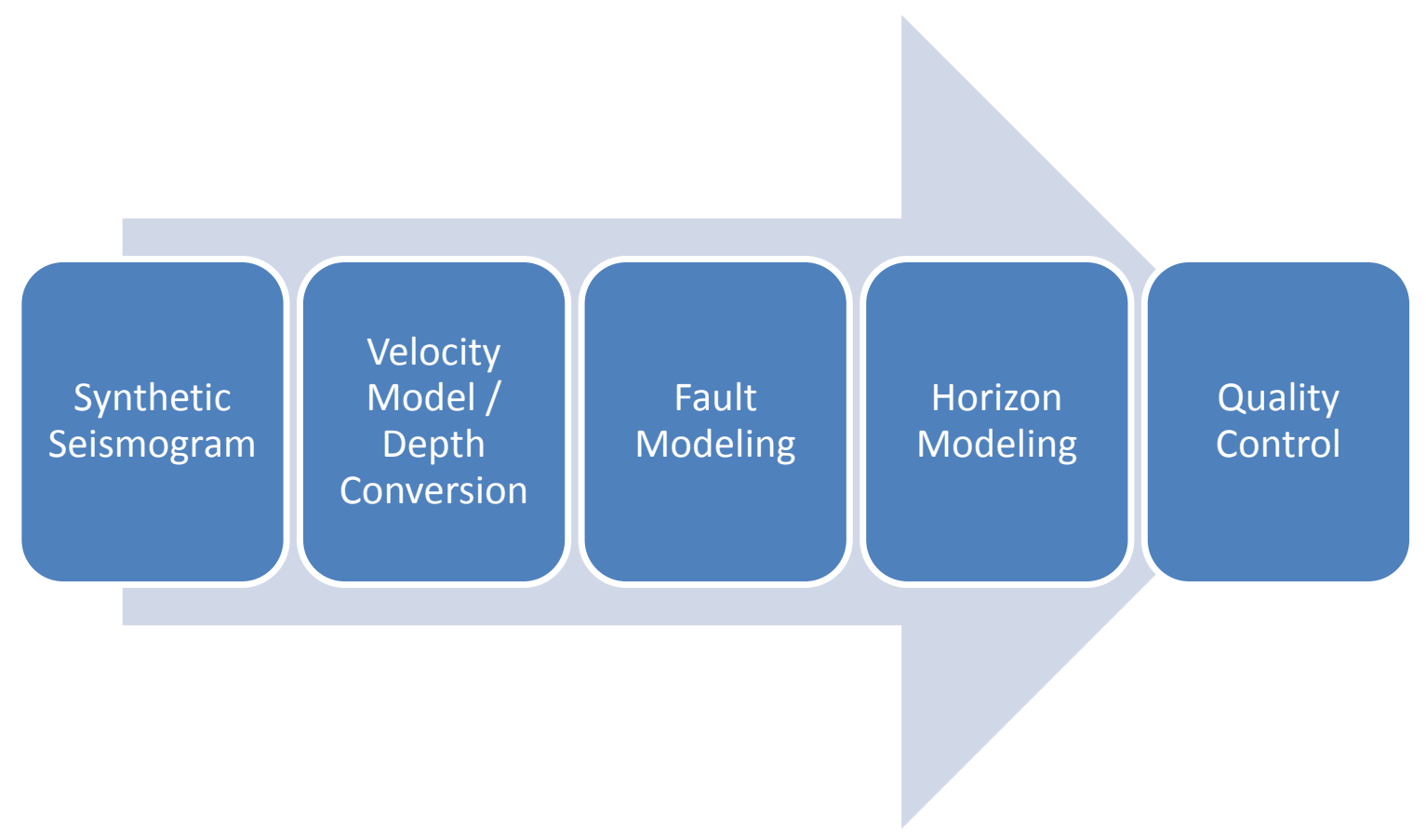

Figure 23. The workflow used in the research to provide low displacement imbricated thrust and back thrust fault model (Fault Model 1) and the kink band fold/fault model (Fault Model 2). 


\subsection{Results/Discussion}

\subsubsection{Depth Conversion}

Formation tops were picked in wells to a high degree of certainty in this data set. Formation tops are later used to compare the accuracy of the velocity model (Figure 24). The synthetic seismogram required shifting in order to provide a tie to the seismic data (Figure 25). The synthetic seismogram revealed that the bright negative reflector around 900 milliseconds (ms) is the Tully Limestone and the bright negative reflector at $1100 \mathrm{~ms}$ is the Onondaga Limestone. Also, the Sixth Elk Sandstone correlated to a moderately bright positive reflector present at $800 \mathrm{~ms}$.

Due to the lateral and vertical heterogeneity of velocity within the data set certain areas had minimal error in depth conversion, while other locations had large error in depth conversion (Appendix 1). Structure also appeared to affect the quality of the depth conversion. For example, when comparing formation tops from well to horizon picks, wells that were drilled in the highly folded or faulted areas tended to have more error in depth conversion. 




Figure 24. Formation tops picked using gamma-ray, density, and neutron logs. In order from the left to the right: 033-26848 is the core well, 033-22015 and 033-21923 are the listening wells for the microseismic, well 033-21396 is used for the synthetic seismogram, and the last well on the right is located outside of the data set in eastern Clearfield County, but includes dipole sonic logs used for computation of geomechanical properties (Chapter 9). 


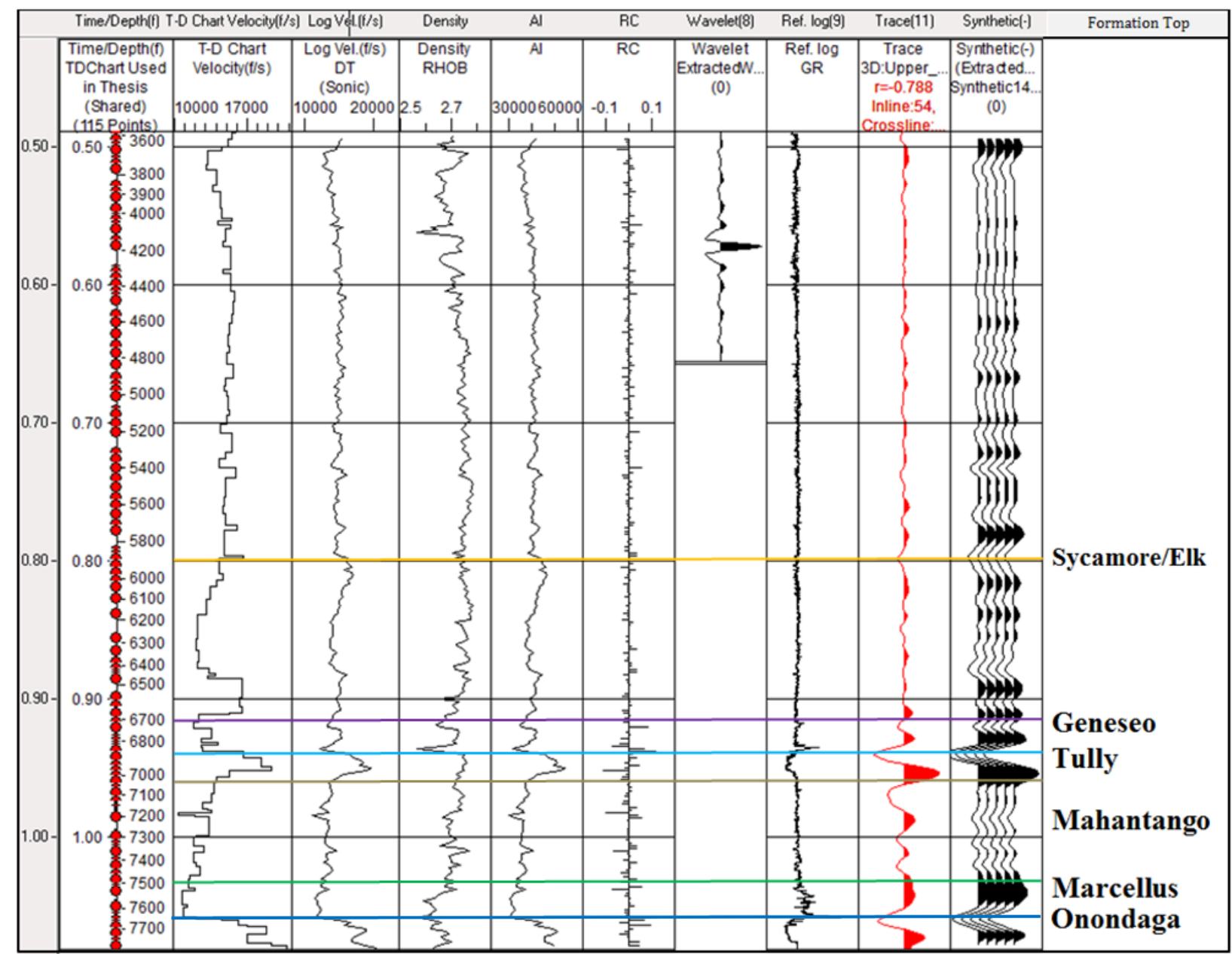

Figure 25. Synthetic seismogram produced in SMT ${ }^{\text {TM }}$ software for well 033-21396. Depth is from 2400 above sea level. 


\subsubsection{Fault Model 1}

Fault model 1 consists of low displacement imbricated fore thrusts and back thrust with near vertical cross-strike, strike-slip/transfer faults. Only larger scale faults that cross cut multiple strata are included within this model. Areas where faults are interpreted tend to have low reflectivity. Twelve along-strike faults and eight cross-strike faults were recognized. In Fault model 1 along-strike faults trend at 040NE and cross-strike faults trend at 330NW (Figure 26).

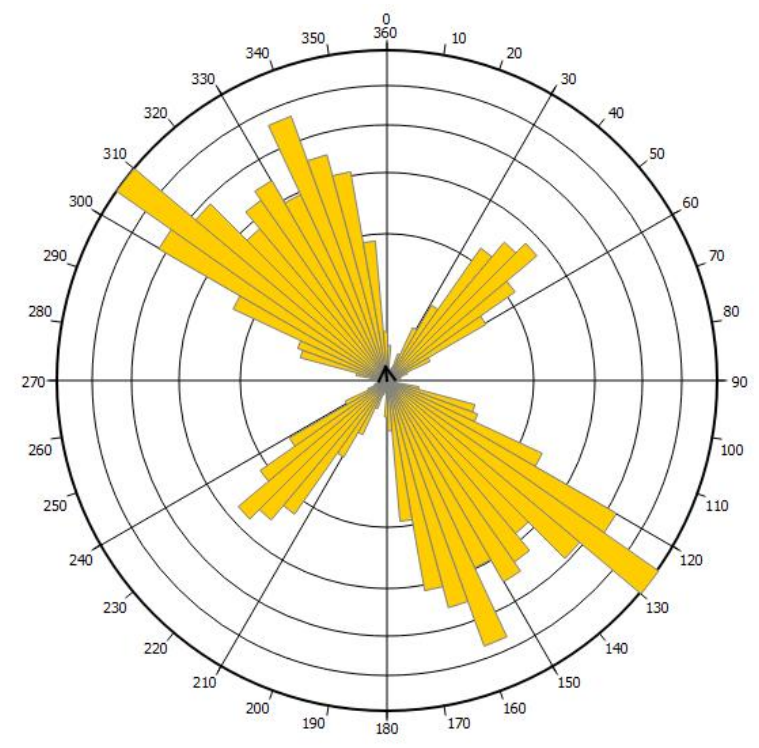

Figure 26. Rose diagram showing fault orientations for this data set. Along strike faults are orientated from 030-060NE and cross-strike faults are oriented from 300-350NW. Scaling of the rose diagram is done by area of the fault plane.

Along-strike faults originate within the Salina Group and terminate within the Skaneateles Formation (Refer to figure 27 for color coded formations). Displacement along the 040NE trending faults is reliant upon a detachment surface within the Salina Group. Multiple salt units exist within the Salina Group, however the resolution of the seismic data cannot depict individual salt units responsible for the fore thrusts and back thrusts. Fore thrust and back thrust faults (structures 1-11 on Figure 29 A-A’ \& B-B') are interpreted to have formed perpendicular 
to the paleo-maximum horizontal stress direction, and propagated up from the basal detachment with all the deformation focused at the fault and within a broad poorly defined back limb (Figures 28 and 29). In structures 1,2, 6, and 7 displacement is constant in the Helderburg and Onondaga formations and rapidly decreases into the Skaneateles Formation where the faults tipout (Figures 28 and 29). Due to the resolution of the seismic data the displacement at the fault tip is uncertain (Figures 28 and 29). The low displacement imbricated thrust faults are similar in nature to fault propagation folds in that fault displacement decreases up-section (Figure 30a) (Mitra, 1990). However, some structures show a defined footwall syncline supporting the interpretation for break-thrust geometry ( structures 3 and 8; Figure 29 A-A’ \& B-B) (Willis, 1893). In break thrust folds structures asymmetric folding toward the foreland reaches a strain threshold and then faulting occurs (Figure 30b) (Willis, 1893). Ultimately, the low displacement imbricated thrust fault structures are similar to break thrust fault folds because of a footwall syncline, but are similar to fault propagation folds in the sense that fault tips propagated from the Salina Group upward into the Marcellus Formation allowing the lower strata to experience more displacement.

Fore thrusts that terminate near the same point as back thrusts tend to have more displacement in comparison to stand alone thrusts (Figure 28; Figure 29; and Appendix B). The most southern pair of fore thrusts and back thrusts (structures 1-2) correlate to the surface mapped Chestnut Ridge anticline (Figure 28, Figure 29 A-A'). Referring to the structural classification proposed by Scanlin and Engelder (2005) the Chestnut Ridge anticline is interpreted as a thrust cored anticline that consists of three zones; the basal detachment zone within the Salina Group, overlain by an imbrication zone within lower Devonian to lower upper Devonian strata, and followed upward by an accommodation zone. In Scanlin and Engelder 
(2005) displacement within the imbricated zone is accommodated by large-scale folding within the accommodation zone. However, an accommodation zone could be present but under the resolution of the seismic data. In Clearfield County the thrust core anticline is present within the imbricated zone, but no large scale folding is observed within an accommodation zone.

Displacement within the imbricated zone in Clearfield County is much smaller in comparison to the thrust core as proposed by Scanlin and Engelder (2005). Faulting within the imbricated zone in Clearfield County appears to be accommodated by sub-seismic scale thickening within the Skaneateles Formation. Sub-seismic scale thickening between the fore thrust and back thrust is likely responsible for the pop-down structures and subsequent salt migration (Figure 29 A-A' and B-B').

As modeled cross-strike faults originate at different locations within the Upper Silurian strata mostly within the Rose Hill Formation and Lockport Formation and terminate within the Upper Devonian Elk sandstone or siltstone (known as the Brallier Formation in West Virginia). Vertical displacement ranges from 100 to 200 feet (30 to 60 meters) (Figure 29 C-C' and D-D'). Cross-strike faults are interpreted to extend over distances of up to 13,000 feet, ( 400 meters) which is comparable to previous interpretations (Faill et al., 1989) (Figure 10) of cross-strike faults extending over distances of up to 6 miles $(\sim 10 \mathrm{~km})$. Cross cutting relationships between along-strike faults and cross-strike faults indicate that deformation was simultaneous. In other words along-strike faults displace cross-strike faults and cross-strike faults displace along-strike faults. No gravitational sliding or syndeposition of the cross-strike faults indicate a late stage Neo-Acadian fault regime in this area (Jacobi et al., 2103). Instead, the structures within this area are interpreted as related to the Alleghenian orogeny. The final outcome from the horizon 
and fault modeling is faults, horizons, and zones which are later used for a geocellular model (Figure 31).

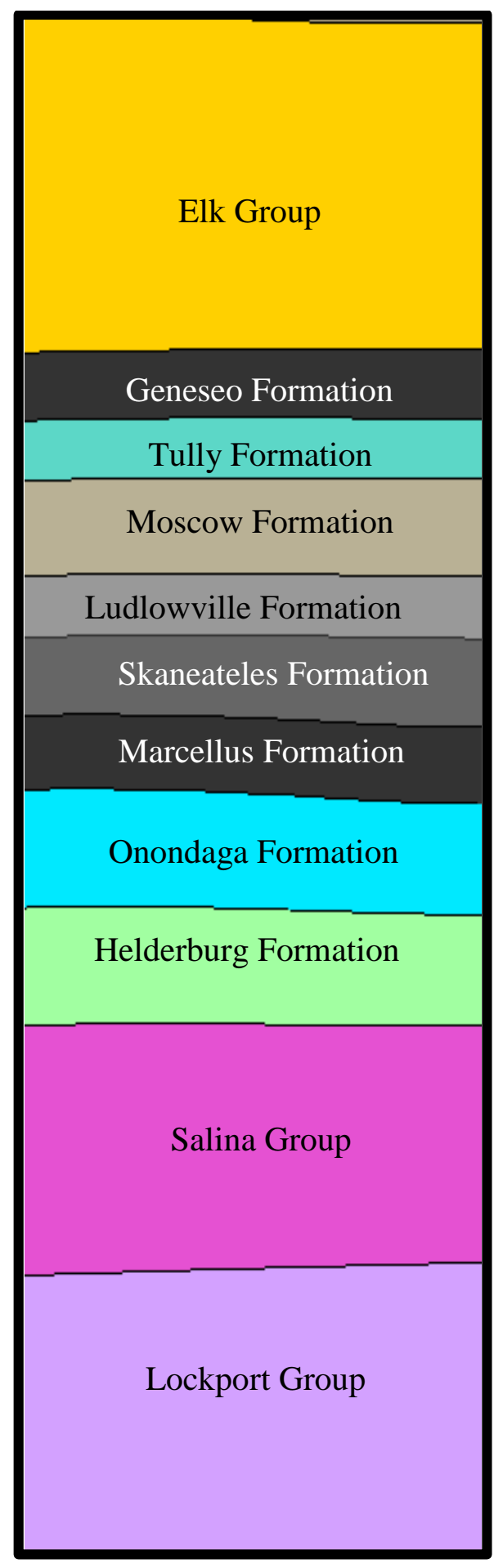

Figure 27. Stratigraphic column showing the stratigraphy within cross-sections for both fault models. 


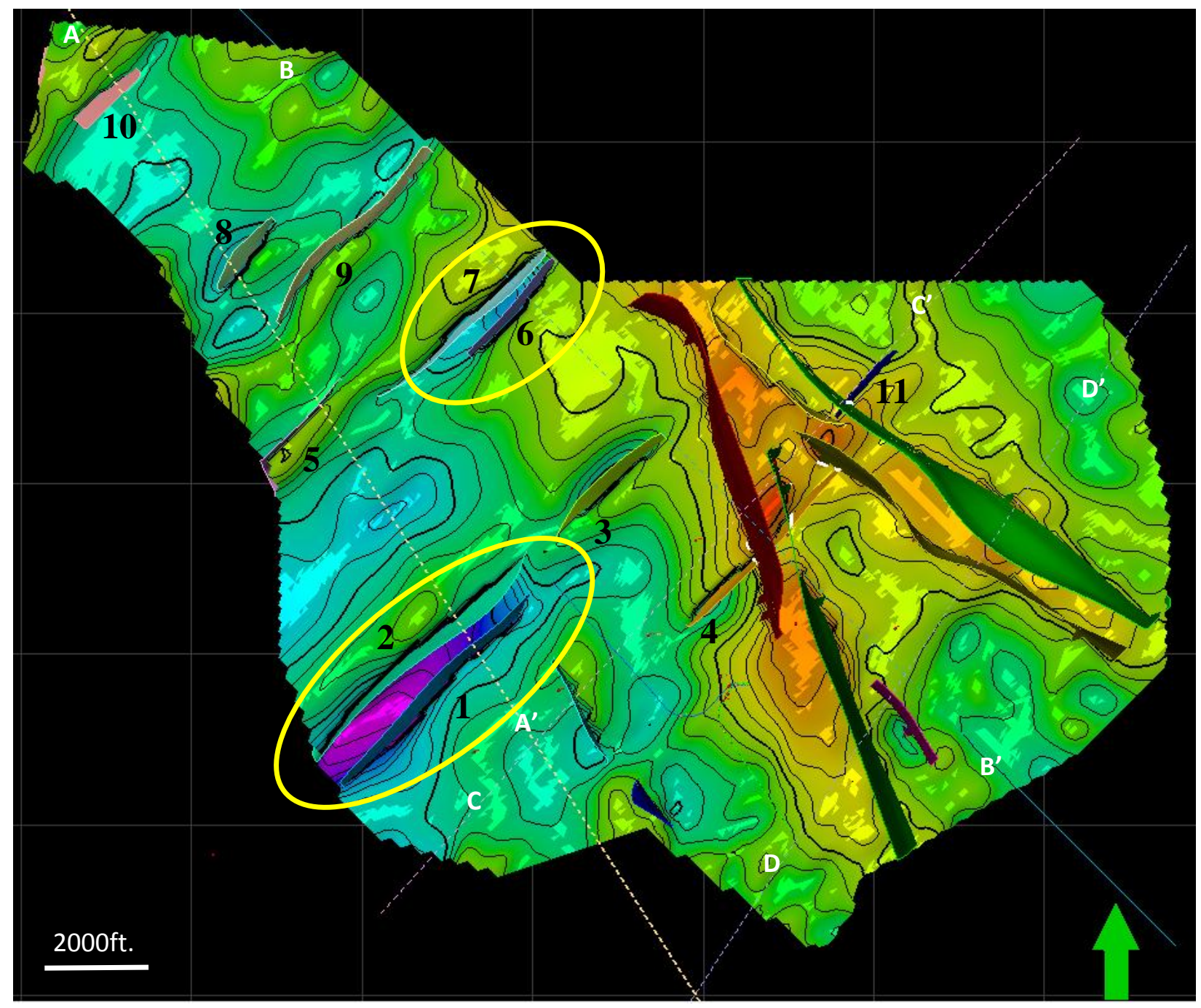

Figure 28. Onondaga horizon (Base Marcellus) with the faults picked in Fault model 1. Circled in yellow are the faults with more displacement. Cross sections A-D are indicated by lines. 



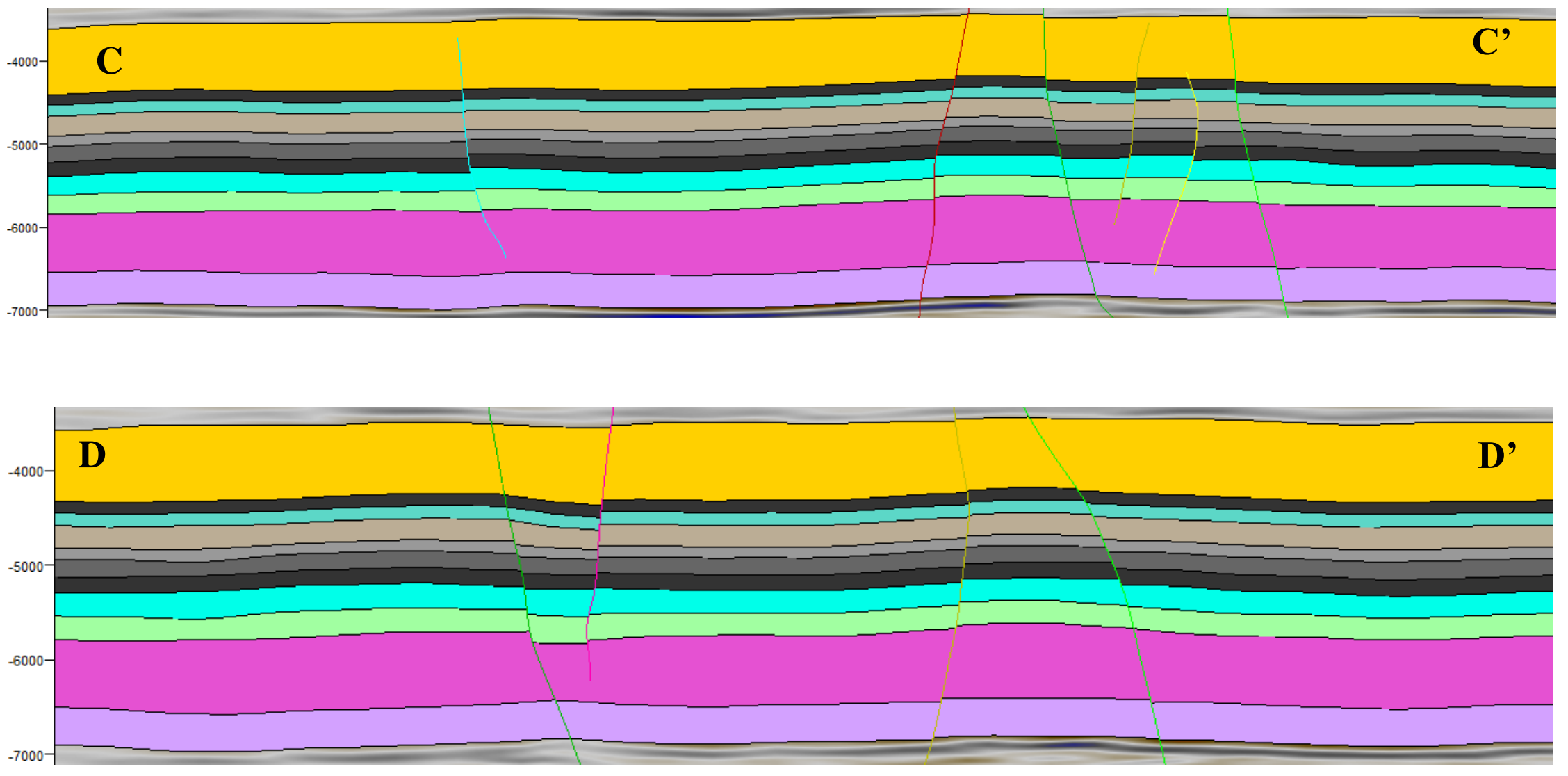

Figure 29. Cross-sections $A-D$. Cross section $A-A$ ' shows the higher displacement fore thrust and back thrust pair. This structure correlates to the surface mapped Chestnut Ridge anticline. Cross-section B-B' shows another higher displacement fore thrust and back thrust pair. Cross-sections C-C' and D-D' show the near oblique vertical strike-slip faults. Notice the scale bar on the left, side of the cross-sections, the horizontal to vertical scale is $1: 1$. Formations are identified according to the color scheme in figure 28. 

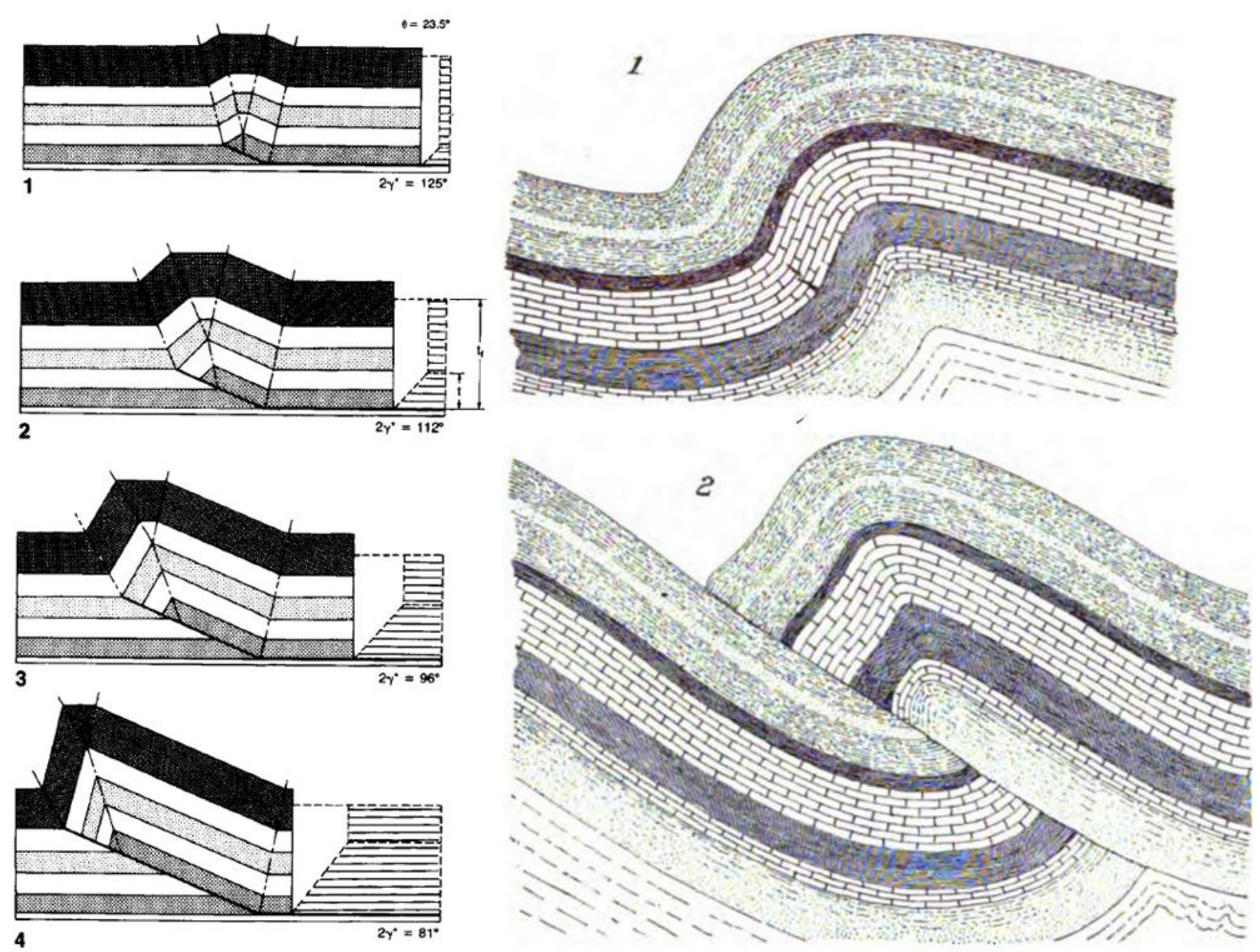

Figure 30 a) Sequential model of a fault propagation fold showing increased displacement downsection (Mitra, 1990). b) Sequential model of a break thrust fault with a defined footwall syncline (Willis, 1893). 


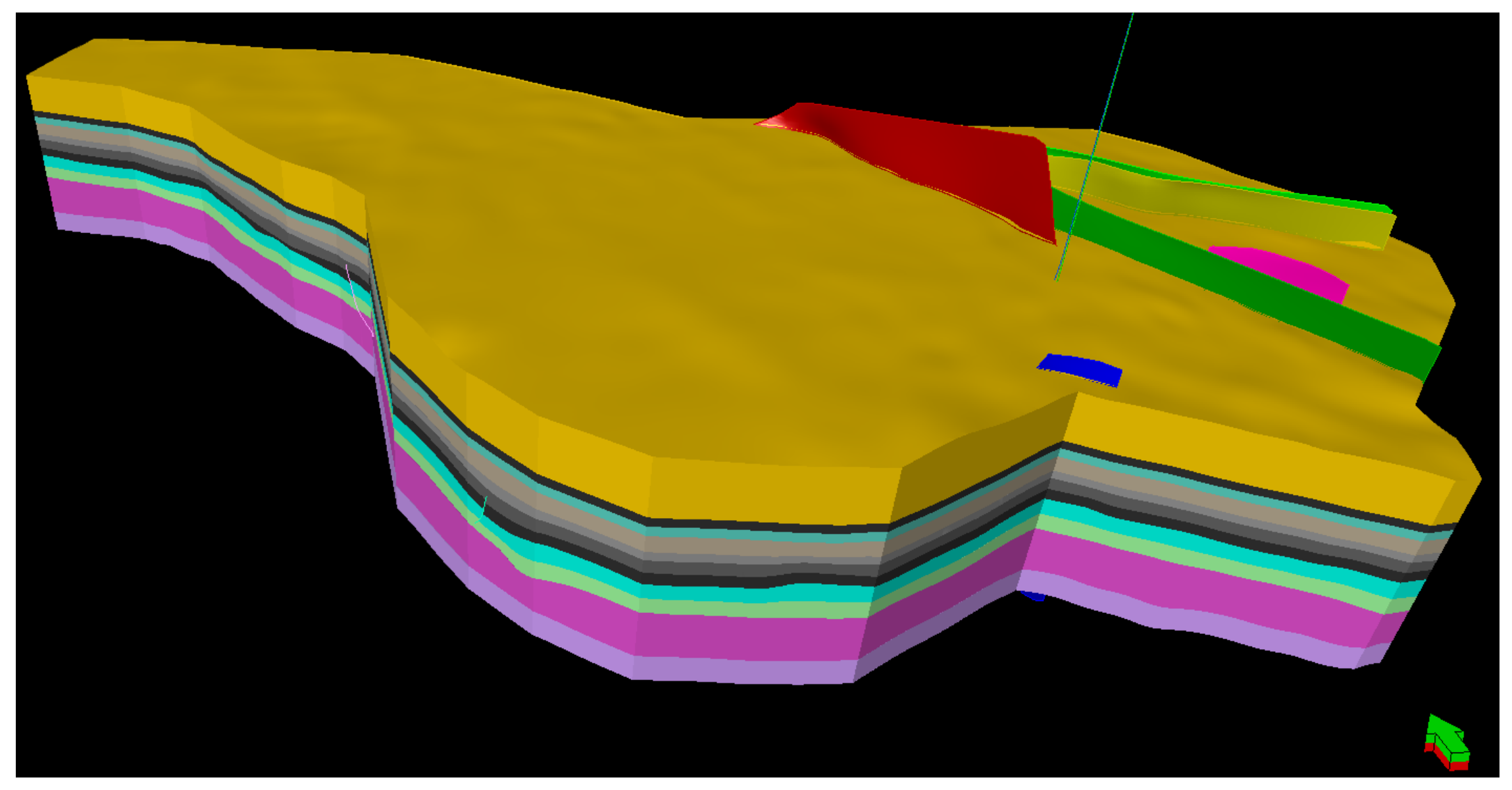

Figure 31. The final outcome from Fault model 1 including faults, horizons, and zones. This data is used for the geomechanical model in the subsequent section. 


\subsubsection{Fault Model 2}

Fault model 2 consists of kink band folds and cross-strike, strike-slip faults. Along strike faults in Fault mode 1 tended to be at areas that had low reflectivity. These areas of low reflectivity in Fault model 2 are interpreted to be highly inclined beds in kink band structures. Kink bands can either be standalone kinks (monoclines) or conjugate pairs. There are fourteen interpreted kink band structures and eight cross-strike faults. Similarly to Fault model 1 kink band axial surfaces trend at 040NE and cross-strike faults trend at 330NW (Figures 32 and 33).

Kink band geometry is observed from the top of the Salina Group to the base of the Tully Limestone. Detachment surfaces above (Moscow Formation) and below (Salina Group) restrict the growth of the kink band geometries. While kink band folds have been studied intensely their genesis is not entirely understood. While Fault model 1 along strike faults formed perpendicular to the paleo-maximum horizontal stress, kink band folds form oblique to the paleo-maximum horizontal stress (Fossen, 2010). Constraining the exact obliqueness of the kink band folds with the given data was not possible.

In Fault model 2 a conjugate pair of kink band folds (CP1) correlates to the surface mapped Chestnut Ridge anticline (Figure 32). Due to the resolution of the seismic data the shallow dipping surface mapped Chestnut Ridge anticline is not observed. Two sets of conjugate pair kink folds (CP1\&2) are present within this data along with numerous monocline kink bands (M1-10) (Figures 32 and 33). The geometry of the conjugate pair better fits the seismic data in comparison to the fore thrust and back thrust of Fault model 1. For example, the basic geometry of the kink band fold puts the area between the two kinks at a lower level, addressing the popdown structure issues. Also, sub-seismic scale folding and thickening at the upper hinge point 
(within the Moscow Formation) seems to fit better in comparison to the sub-seismic scale thickening interpreted in Fault model 1. For these reasons, Fault model 2 is preferred.

The cross-strike interpretation is the same for both models the only difference is that the faults are not cut by along strike faults they are merely folded. However, both interpretations do not reveal a difference in timing of the deformation. Both fault models support a prolonged deformation period during the Allegheny orogeny.

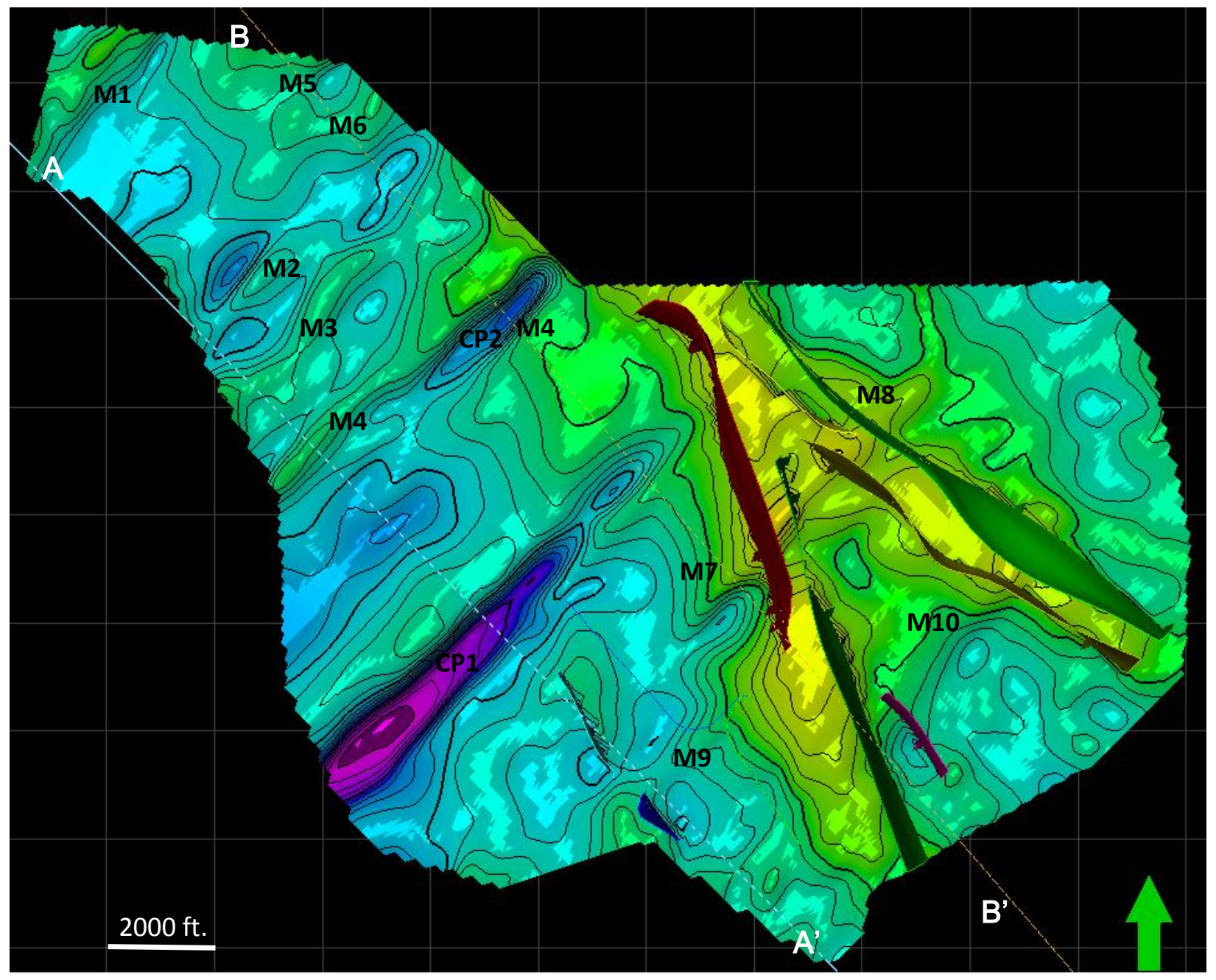

Figure 32. Onondaga (base Marcellus Formation) horizon in Fault model 2 with locations of cross-sections A-B. 

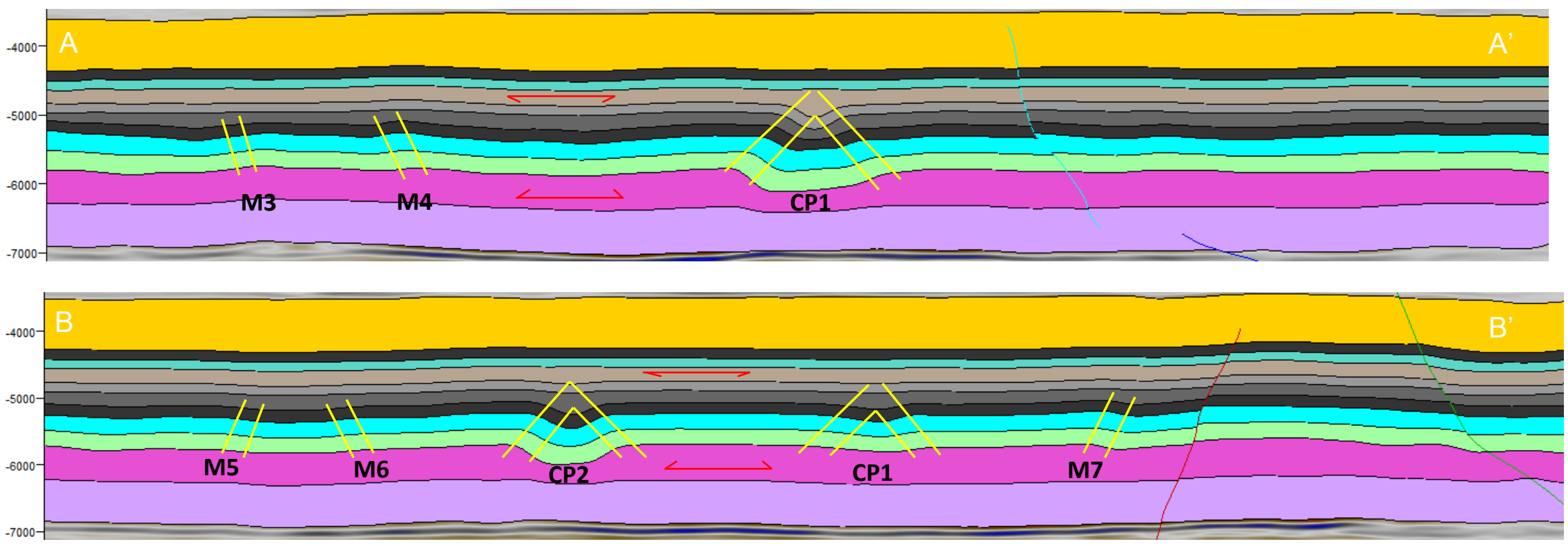

Figure 33. Cross-sections A - B. Cross section A - A' shows higher displacement conjugate pair kink band folds (CP1) and lower displacement monocline kink bands (M3\&4). The CP1 structure correlates to the surface mapped Chestnut Ridge anticline. Crosssection B-B' shows another higher displacement conjugate pair kink band fold (CP2), and lower displacement monocline kink bands (M5-7). Notice the scale bar on the left, side of the cross-sections, the horizontal to vertical scale is 1:1. Formations are identified according to the color scheme in figure 28. 


\section{Geomechanical Modeling}

\subsection{Geomechanical Modeling Methodology}

The geomechanical modeling workflow used for this research is software driven. The software used is the geomechanical modeling and strain modeling tool in Midland Valley Move ${ }^{\mathrm{TM}}$ software. The kink band model (Fault model 2) is analyzed using a workflow containing five major steps (Figure 34). The kink band model is used because it better resolves the pop down structure and sub-seismic scale thickening issues. The final product from this workflow provides insight on how geomechanical properties are effecting natural gas production in Clearfield County, Pennsylvania.

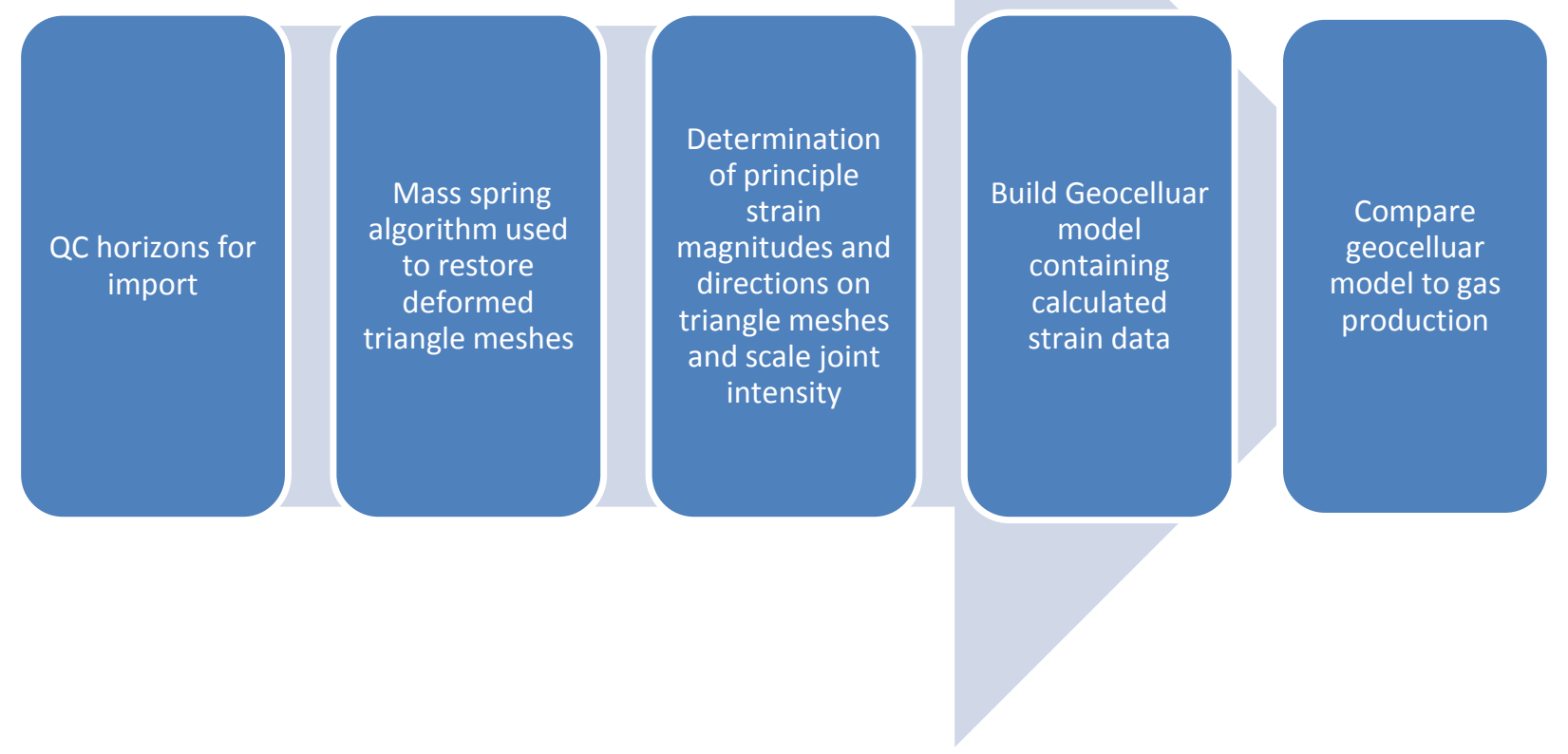

Figure 34. Workflow used to analyze geomechanical properties and how they affect production capability in Clearfield County, Pennsylvania. 
The first workflow step is to check the validity of the modeled horizons. By comparing the down sampled horizons that were produced from the horizon modeling algorithm in Schlumberger's Petrel ${ }^{\mathrm{TM}}$ software, back to the seismic data. The horizon meshes were down sampled so the following algorithms could run efficiently.

The second workflow step utilizes a computer assisted mass-spring algorithm in Midland Valley Move ${ }^{\mathrm{TM}}$ software (Figure 35). The algorithm ultimately restores all deformed meshes to a target mesh. The target mesh in this work flow is a flat mesh. The first step in the mass spring algorithm is a discretization process. Discretization makes the triangle mesh intersections constant mass values and triangle mesh sides constant spring stiffness values. These parameters allow for the utilization of Hooke's law and Newton's second law for resolving force and displacement between deformed meshes and target meshes. Secondly, the deformed mesh is given target mesh boundary conditions. In this process the user defines how to resolve fault cuts. The fault cuts in this workflow were pinned at the fault tips and restored half way between the hanging wall and footwall. The final step is an elastic energy minimization. Iteratively solving for the displacement over small time steps, and moving the masses within the target surface allows strain to distribute through the mesh according to the spring elasticity. The restoration is complete when equilibrium is reached and movement of the masses ceases. The elastic energy minimization resembles rock deformation in the manner that rocks deform by releasing the least amount of elastic energy. 


\section{The mass-spring solver}

1) Discretization: represent a deformed (or undeformed) mesh as $\mathrm{m}$ asses and springs

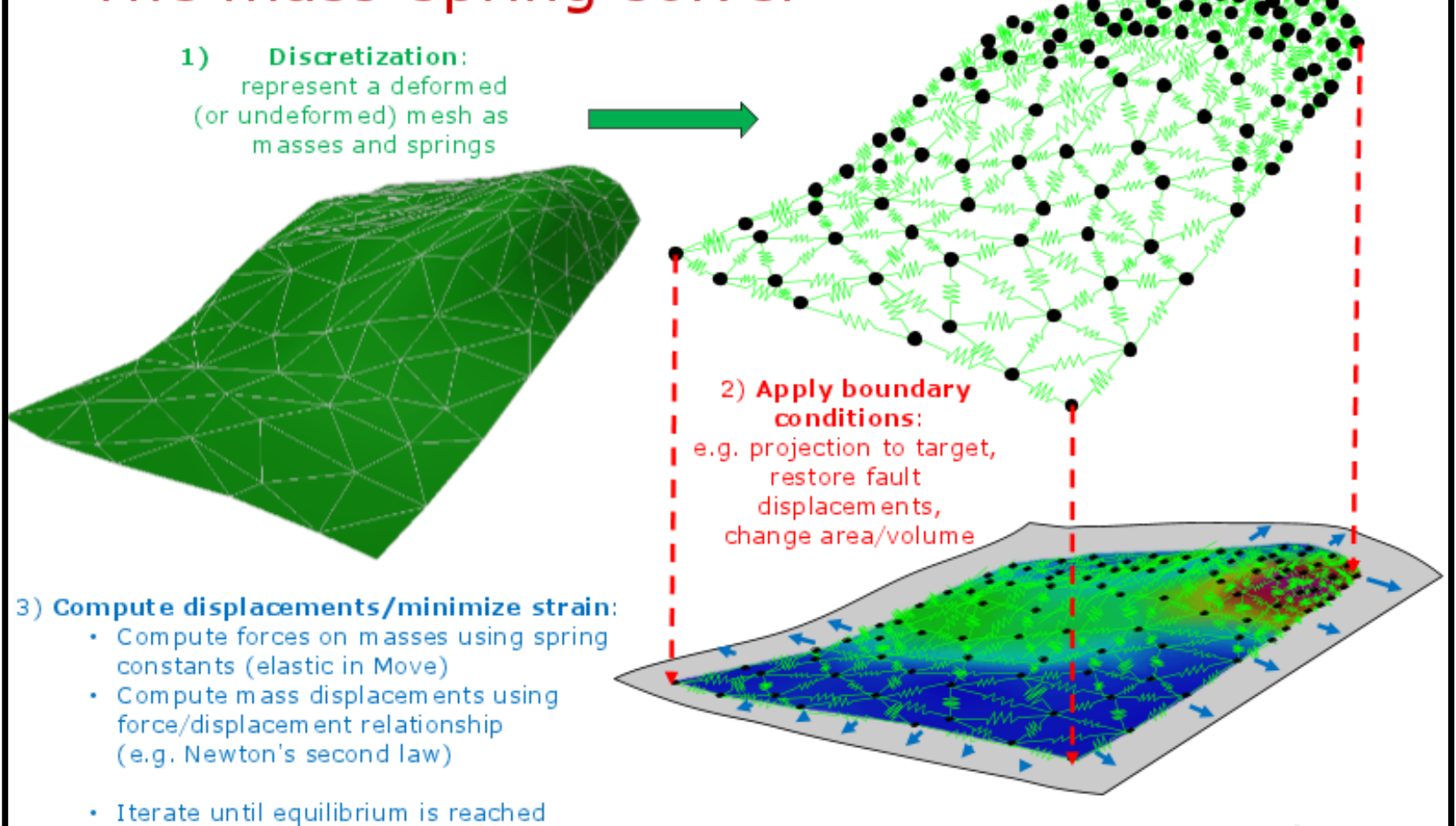

- Iterate until equilibrium is reached

Figure 35. Mass spring solver workflow adopted from Midland Valley Move ${ }^{\mathrm{TM}}$ software.

The third workflow step uses the geometry of the deformed and restored meshes and the displacement values tied within them to automatically resolve strain tensors and Eigen vectors from a constant strain triangle calculation. The strain tensor and Eigen vector values ultimately determine the principle strain (En) magnitudes and directions that are used for the geocellular model (step 4). E1 is maximum elongation or tension and E3 is minimum elongation or tension. The two attributes in this workflow are E1 and the ratio of E1 to E3. When maximum tension (E1) is high, mode one tensional fractures are more likely to develop. When differential strain (E1/E3) is high, shear mode fractures are more likely to develop (Fossen, 2010).

The fourth workflow step is to convert the meshes with strain attributes within them to a geocellular body. First, to enhance visualization Midland Valley Move ${ }^{\mathrm{TM}}$ software builds 
meshes between meshes. The meshes are built by applying an average function between meshes. Then the geocellular body with strain attributes is built. Geocellular bodies are critical in data visualization.

The fifth workflow step is to compare magnitude of strain attributes at or around the well bores to gas production, which highlights whether increased fracture development in Clearfield County assists or hinders gas production. 


\subsection{Geomechanical Modeling Results}

Fault model 2 meshes were resampled in order for the mass-spring algorithm and strain determination algorithm to work proficiently. Figure 35 displays the geometry of the triangle meshes required for the model to work efficiently. Figure 36a shows the results of resampling the Fault model 2 meshes. Meshes were checked with the depth converted seismic data for quality assurance purposes (Figure 36b).

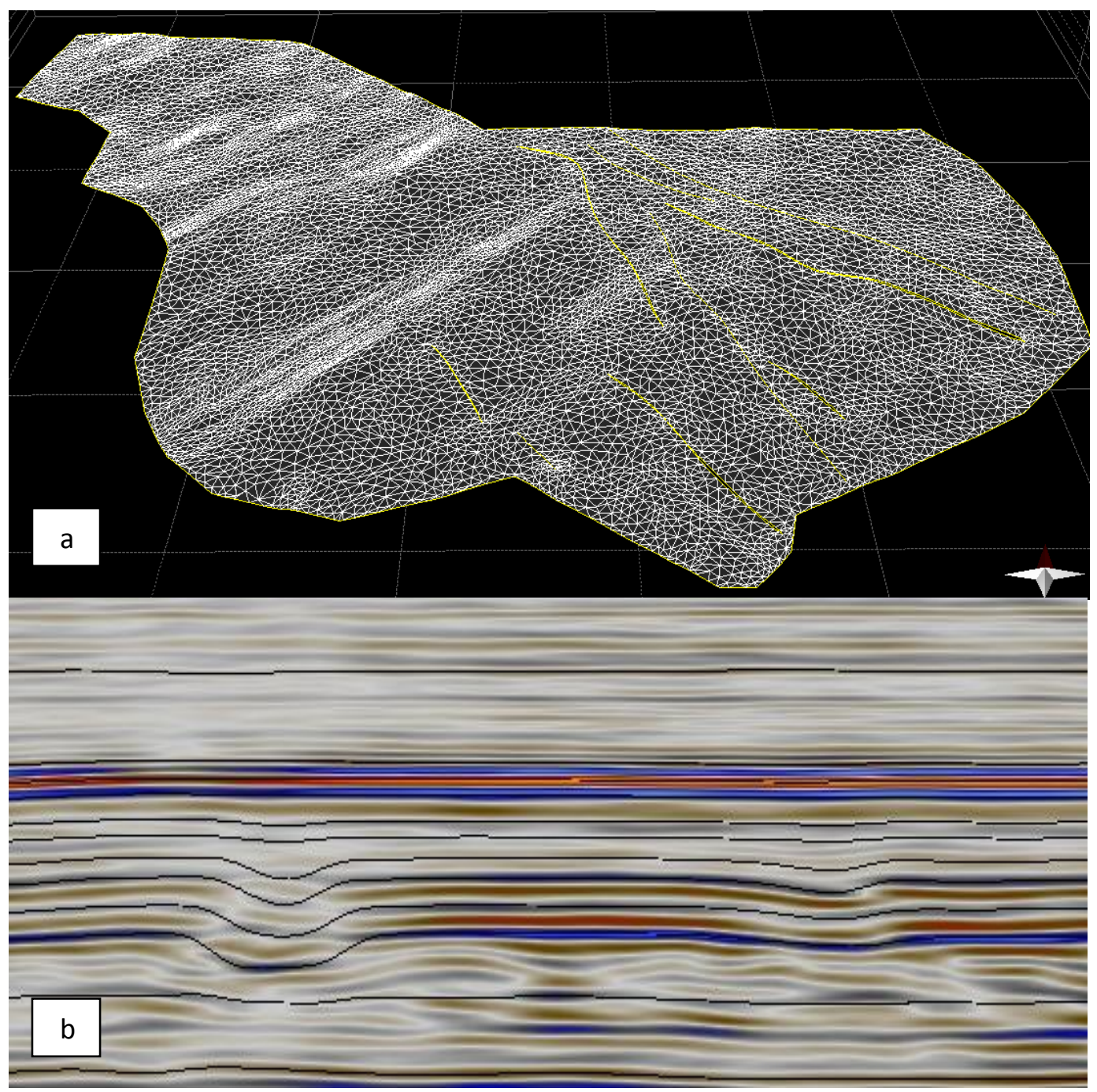

Figure 36. a) Results from resampling a triangle exported from Schlumberger Petrel ${ }^{\mathrm{TM}}$. Notice the geometry of the triangle mesh intersections and sides match that of figure 35 . b) Results of quality checking the resampled meshes in Fault model 2. 
Discretization is the first step in the mass-spring algorithm; however no results are available for this portion of the algorithm because it is a process that is built within the software. The $x-y$ boundary conditions of the mass spring model are the same as the kink band model. A total of 108 fault cuts were pinned in order for the hanging walls and footwall to meet half way (Figure 37a). The final product of the mass spring algorithm was a successful restoration of all layers within Fault model 2 (Figure 37b). The algorithm also provided a successful geometric definition for the determination of principal strain magnitudes and directions in the subsequent step.

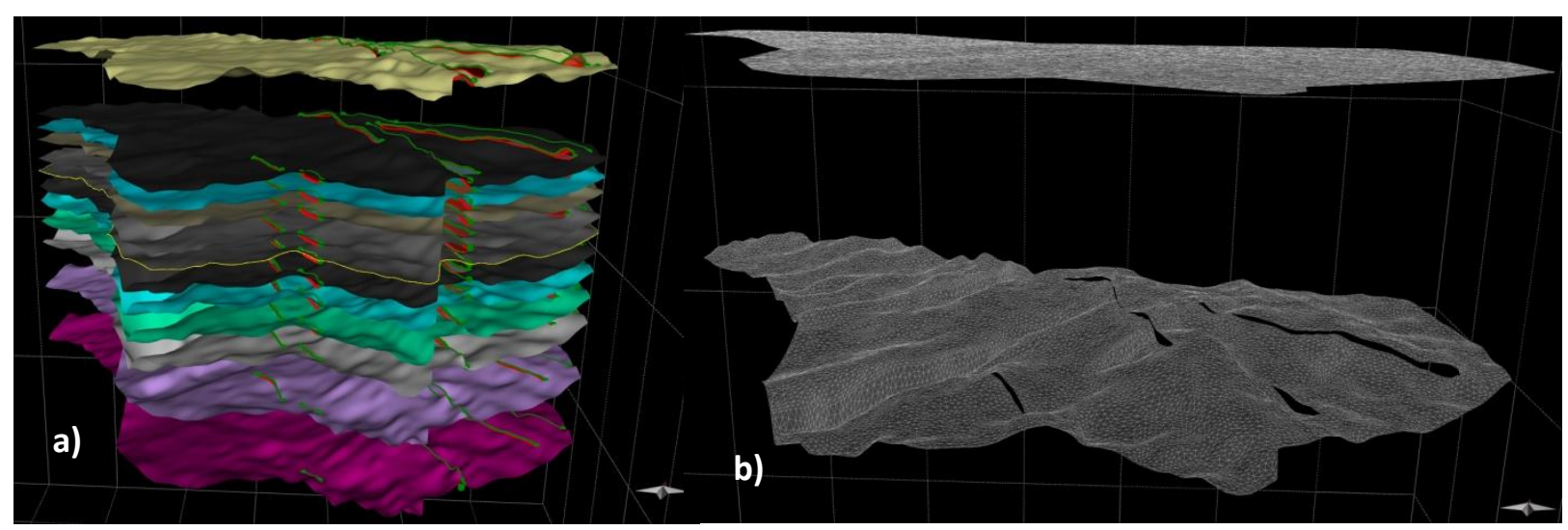

Figure 37 a) All twelve horizons with the interpreted fault cuts that meet half way between the hanging wall and foot wall in step two of the mass spring algorithm. The figure is at ten times vertical exaggeration. b) The results of restoring the deformed Marcellus mesh to a flat mesh. Five times vertical exaggeration.

The determination of strain principal directions and magnitudes was successful and the results are best observed within the geocellular model (Figure 38). The geocellular model revealed strain distributions in cross section and in map view at various depths. The two strain attributes examined were E1 and E1/E3. Both attributes were focused along fault locations, however subtle differences were observed. 


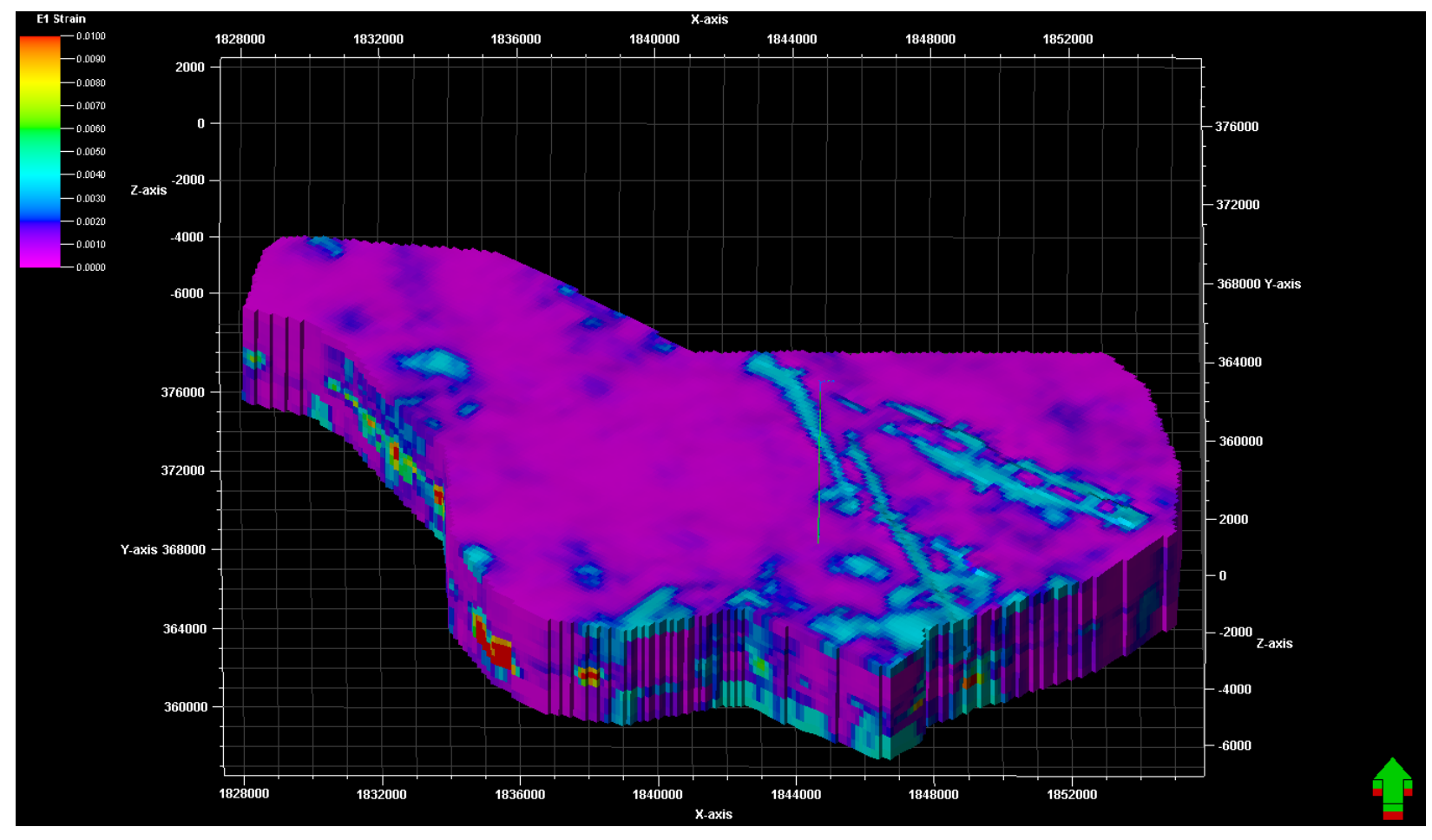

Figure 38. Geocellular model showing E1 strain attribute; no vertical exaggeration.

Increased maximum elongation (E1) is observable along the inclined portion of the kink band folds from the Salina Group to the Moscow Formation. The conjugate pair folds related to the Chestnut Ridge anticline (CP1) is the most prominent along strike structure also carrying the most E1 strain. Monocline kink bands (M1-10) in this dataset do not carry as much joint intensity in comparison to the conjugate pairs (Figures 39a and 40 A-A' \& B-B').

Increased E1is also observable at cross-strike, strike-slip faults from the base of the model to the top (Rose Hill Formation to the Elk Formation). The highest strain related to the strike-slip faults is focused within the Marcellus and Skaneateles formations. One cross-strike fault to the left of well 033-27221 (blue well drilled in the northwest direction in figure 42) was revealed to be a right lateral strike-slip fault according to the E1 strain distribution at the fault 
tips (Figure 42). The increased E1 at the fault tip has been interrupted as a fault damage zone prone to hinder hydraulic stimulation.

Trends in differential stress (E1/E3) closely resemble the E1 trends near the kink band folds. However, E1/E3 seemed to follow the cross-strike faults more clearly. Areas with increased E1/E3 are prone to shear failure (Fossen, 2010). Therefore, E1/E3 values should increase closer to observed faults (Figure $39 \mathrm{~b} \& 41$ ). The center of the cross-strike faults is located in the Onondaga and Marcellus formations (Figure 41C-C'). The Onondaga and Marcellus formations have increased displacement at faults and increased E1/E3 strain. Hydraulic stimulation can reactivate tensional fractures and shear fractures. Hydraulic fracturing to create new fractures is hindered where existing faults and fractures dilate and reduce the pressure that would otherwise be used to create new fractures. Therefore, an increase in E1/E3 directly beside well 033-27221 (blue well drilled in the northeast direction in figure 42) poses risk for effective hydraulic fracturing treatment.

Gas production (first 326 days) per foot of lateral for well 033-27221 (blue well) is approximately half of well 033-27206 (green well). Well 033-27221 (blue well) is drilled in close proximity to highly increased E1 and E1/E3 related to a strike-slip fault. Well 033-27221 (green well) is drilled in close proximity to moderately increased E1 and E1/E3 related to passive folding (Figure 42). Areas with increased maximum elongation (E1) are interpreted to have increased tensional fracture intensity, and areas with increased differential stress (E1/E3) have increased shear fracture intensity. The production data and E1 and E1/E3 strain attributes along the wells supports the interpretation that cross-strike structures carry increased fracture intensity and hindered hydraulic stimulation and gas production of well 033-27221 (blue well) (Figure $42)$. 

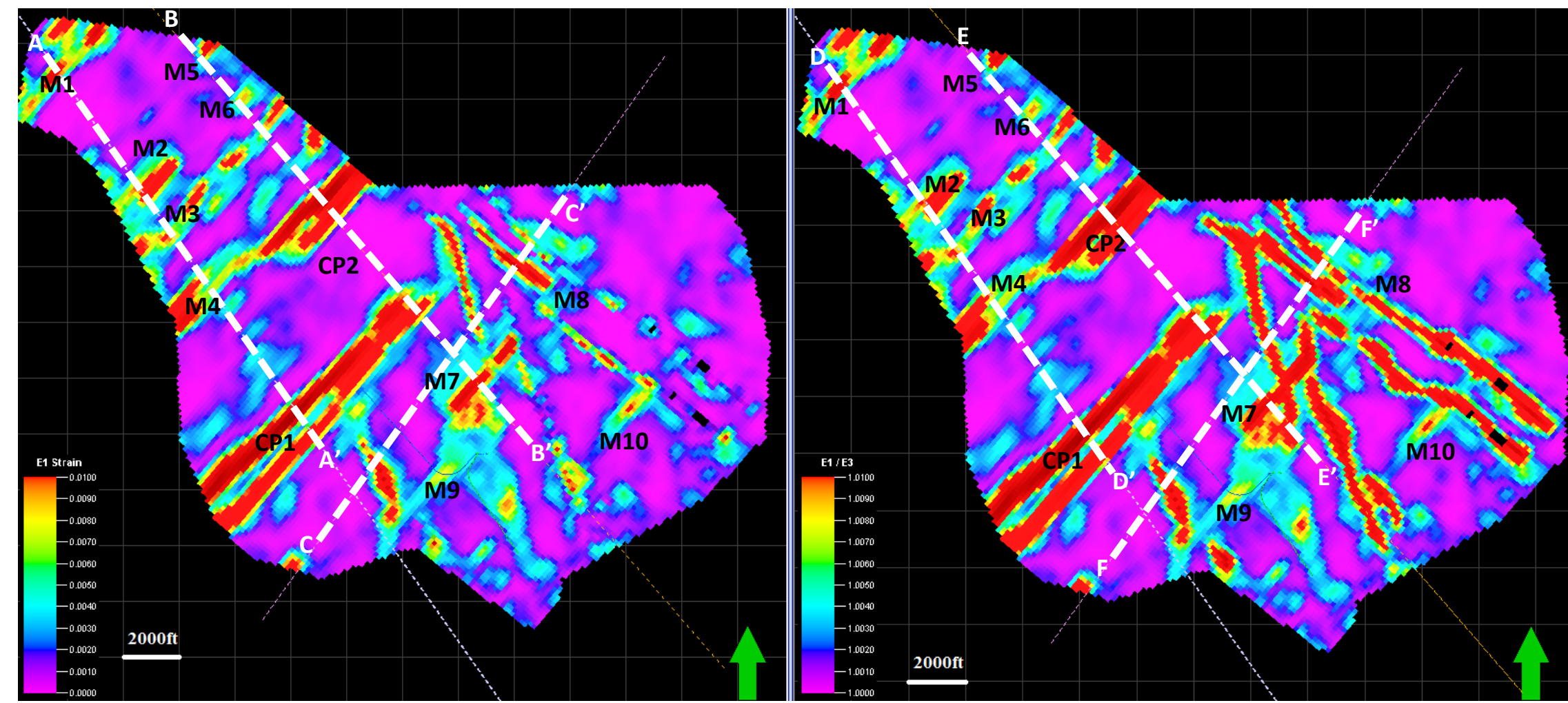

Figure 39. a) Marcellus horizon showing the E1 strain attribute. b) Marcellus horizon showing the E1/E3 attribute. Conjugate pair kink bands are indicated by $(\mathrm{CP})$ and monocline kink bands are indicated by $(\mathrm{M \#})$. CP1 correlates to the surface mapped Chestnut Ridge anticline. Thicker lines are the cross-section lines 

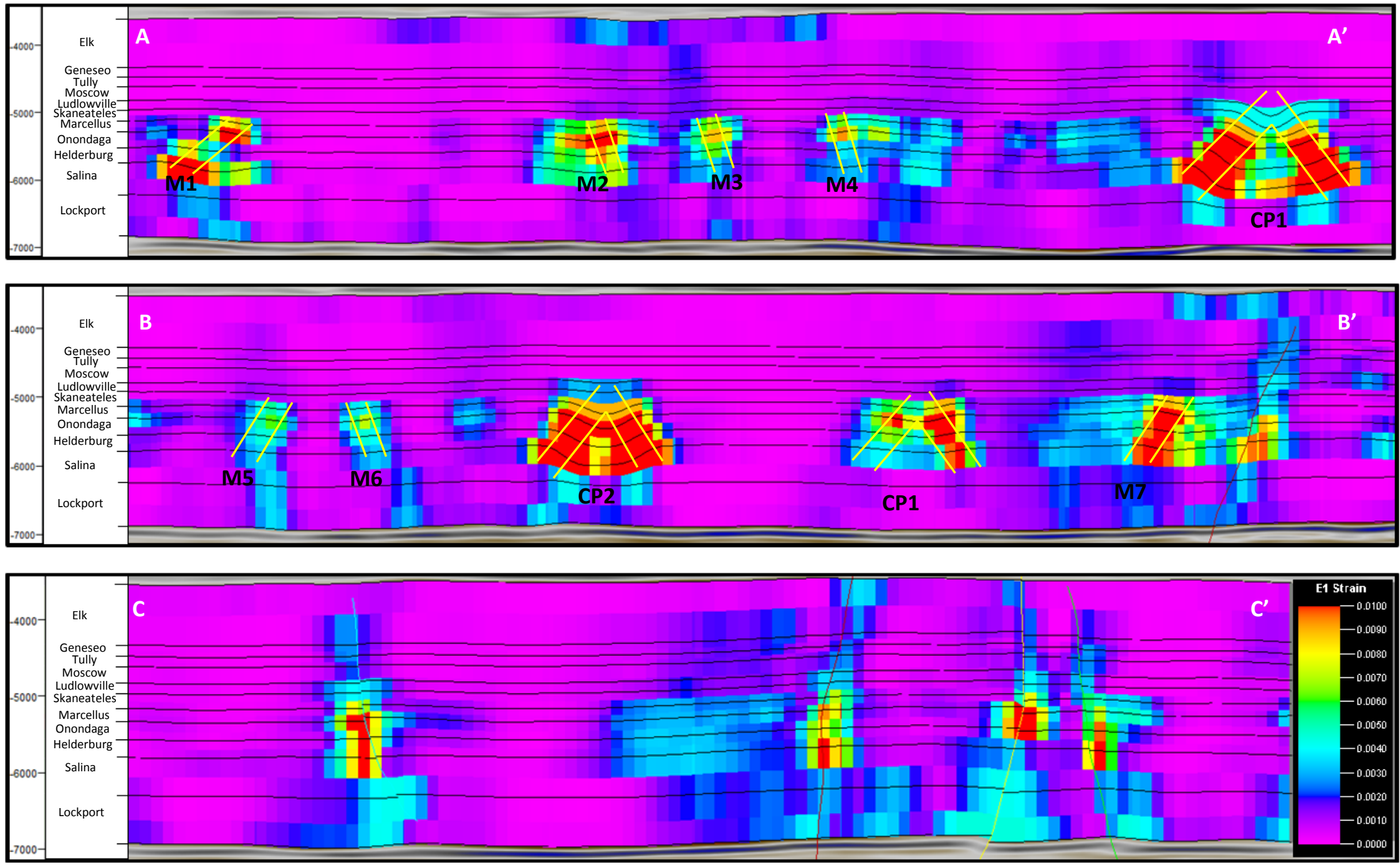

Figure 40. E1 Strain cross section A-C. Axial planes of the kink bands are yellow lines and detachment zones are red arrows. Mentioned in detail in text. Vertical scale to horizontal scale is 1:1. Conjugate pair kink bands are indicated by (CP\#) and monocline kink bands are indicated by (M\#). CP1 correlates to the surface mapped Chestnut Ridge anticline. 

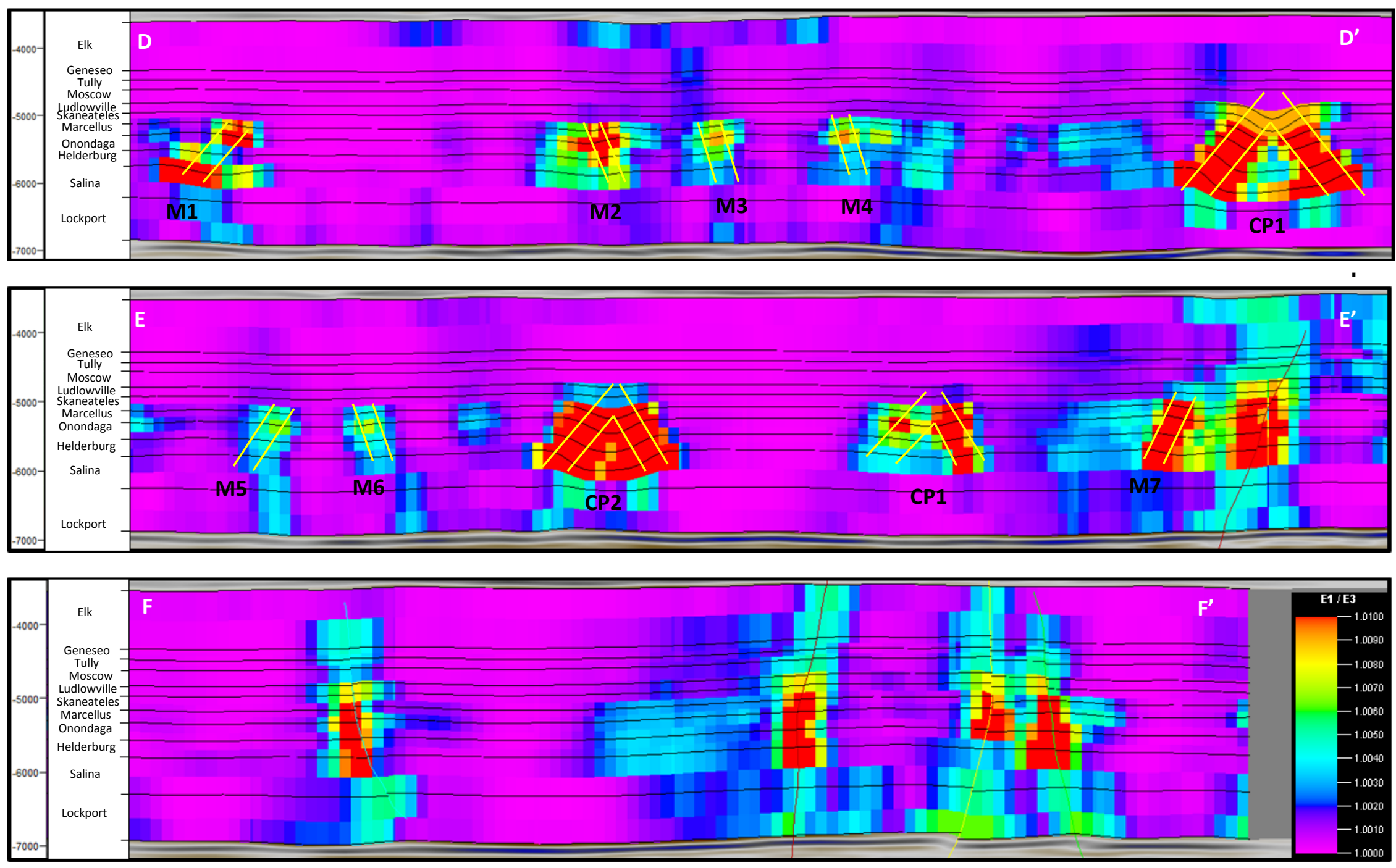

Figure 41. E1/E3 differential strain cross section D-F. Axial planes of the kink bands are yellow lines and detachment zones are red arrows. Mentioned in detail in text. Vertical scale to horizontal scale is 1:1. Conjugate pair kink bands are indicated by (CP\#) and monocline kink bands are indicated by (M\#). CP1 correlates to the surface mapped Chestnut Ridge anticline. 


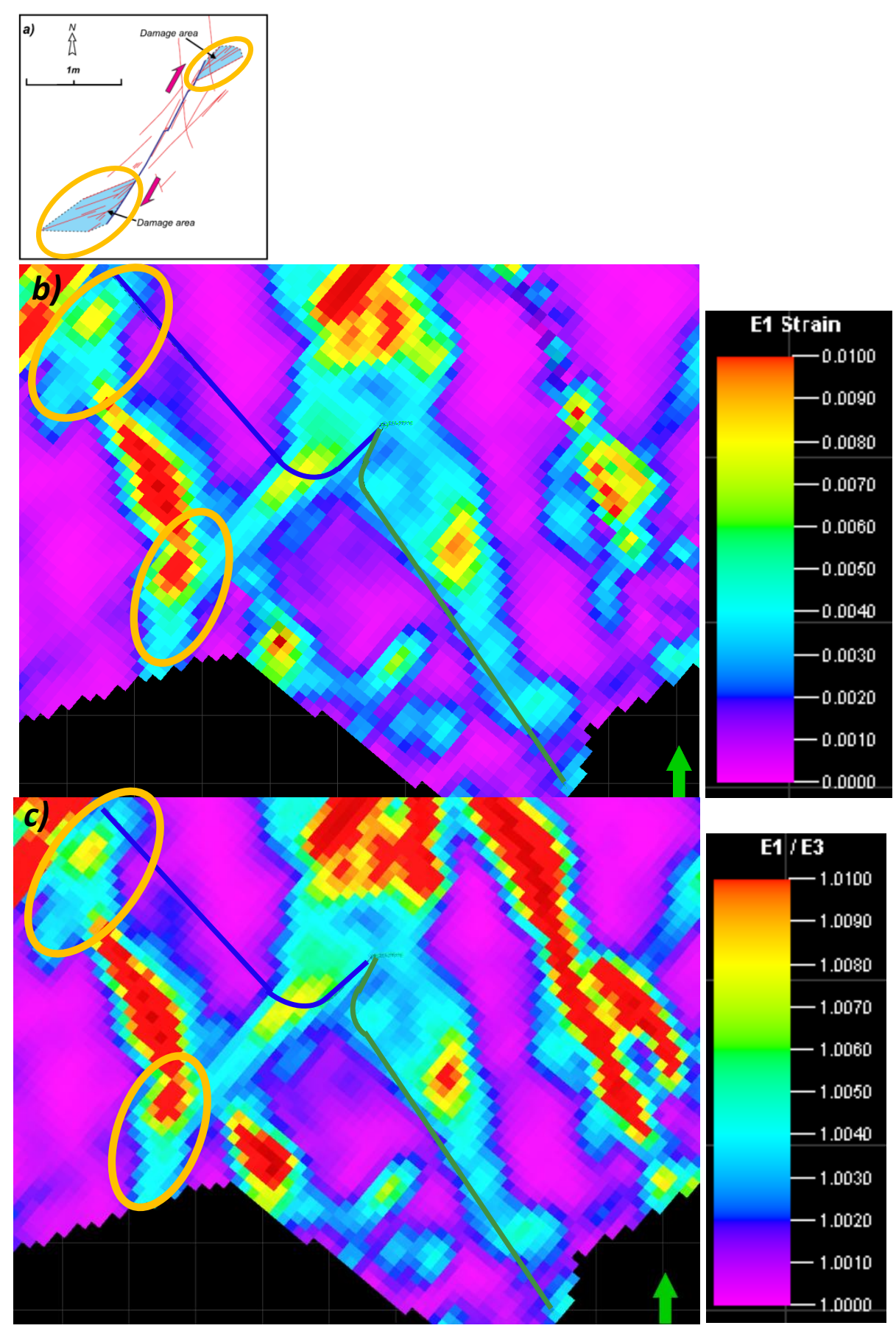

Figure 42 a) Observed strike-slip damage zones modified from (Kim and Sanderson, 2005). b) Interpreted strike-slip fault at the base of the Marcellus Formation with E1 damage zones at the fault tips resembling the model in figure 42a. c) Interpreted strike-slip fault at the base of the Marcellus Formation with differential strain E1/E3 damage zones at the fault tips resembling the model in figure 42a. 


\section{Microseismic Analysis}

\subsection{Methodology}

In order to further investigate the effects of structural complexity, natural fracturing and rock mechanics on gas production microseismic data is analyzed by $r(t)$ plot analysis, $b$-value analysis, and general microseismic event attribute mapping in relation to the fault model and geomechanical model (Wessels et al., 2011; Birkelo and Cieslik, 2012).

Microseismic data was acquired with a down-hole array of geophones in two vertical listening wells. The micro seismic was converted to depth by Schlumberger ${ }^{\mathrm{TM}}$ using high frequency cross well tomography. Schlumberger ${ }^{\mathrm{TM}}$ also reported microseismic event attributes such as moment, moment magnitude, radius, energy, and stress drop. Event attributes are empirically related by various equations (Kanamori and Anderson, 1975).

$\mathrm{R}(\mathrm{t})$ plots include the distance of the microseismic events from the perforation location in relation to time (Figure 43). Treating data such as pumping pressures and rates and proppant control can also be shown. $\mathrm{R}(\mathrm{t})$ plots are used to determine multiple conventional reservoir parameters such as permeability and diffusivity (Angus and Verdon, 2012). However, the purpose of $r(t)$ plot analysis in unconventional shale gas is to estimate the volume of treated reservoir (reservoir that received proppant). Estimation is based on the frequency of events below a user defined $r(t)$ curve. The events that represent area of treated reservoir are then included in an effective stimulated reservoir volume (ESRV) in Schlumberger Petrel ${ }^{\mathrm{TM}}$ software (Birkelo and Cieslik, 2012). Finally, the ESRV is pillar gridded in order to visualize event density. 


\section{Stage 4 - upper and lower wells}

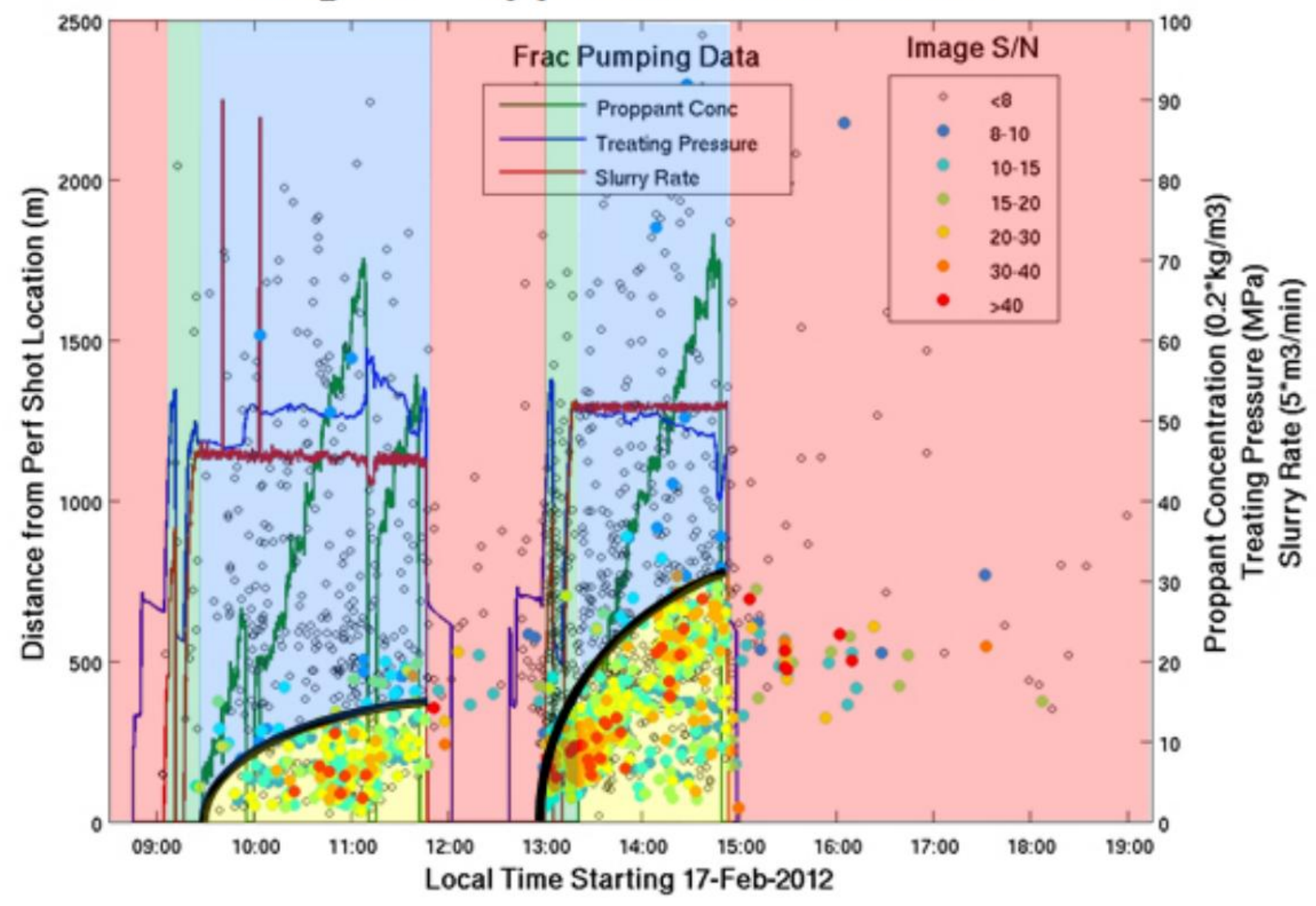

Figure 43. $\mathrm{R}(\mathrm{t})$ plot highlighting in yellow the area that represents the treated zone (Birkelo and Cieslik, 2012).

B-values are solved by plotting event magnitude in a histogram and plotting the number of events in a logarithmic scale; the slope of the histogram is the b-value (Figure 44). Higher seismic events are related to fault movement during stimulation and lower magnitude events are related to fracture development. Therefore, if higher frequency of high magnitude (fault related) events is observed during the stimulation, then the slope of the histogram will be decreased (decreased b-value) (Figure 44). B value analysis can indicate stages that are likely to have more fracture development ( 2) or partial connectivity to faults ( 1) (Wessels et al., 2011) (Figure 44). Therefore a cut off of 1.5 is chosen between fracture dominated events and partially connectivity to fault events. 




Figure 44. B-value histogram showing a partially fault related hydraulic fracturing stage (bvalue $=1$ ) and a fracture dominated hydraulic fracturing stage (b-value $=2)$ (Wessels et al., 2011). 


\subsection{Results}

\subsubsection{R(t) Plot Analysis}

$\mathrm{R}(\mathrm{t})$ plot analysis revealed that events that received proppant did not extend farther than 700 feet from the well bore (Figures 45 and 46b). Stage two best depicts the high frequency of event close to the perforation location. However, the sudden drop in pumping pressure and rate contributes error to the $\mathrm{r}(\mathrm{t})$ plot analysis. As a result, only events before the drop in pressure are included within the stimulated reservoir (Figure 45). The volume of stimulated reservoir is 365,289 acre-feet, which is about half the volume of rock that experienced seismicity $(730,028$ acre-feet) (Figure 46). This agrees with the observation that only half of the fracture distance is propped to provide effective conductivity (Carl Montgomery pers. comm.). Pillar gridding the ESRV allowed for visualization event density, which allows for the interpretation of increased and decreased zones of treatment (Figures $47 \mathrm{a} \& \mathrm{~b}$ ). Event density pillar gridding of the ESRV revealed that stage six did not have an effective stimulation in comparison to the other stages (Figures $47 \mathrm{a} \& \mathrm{~b}$ ). The stimulation was focused on southwest side of the well bore and within the Moscow Formation. Stimulation was not as effective on the northeast side of the well bore (Figures 47a \& b). Data interpreted from the $\mathrm{r}(\mathrm{t})$ plots, ESRV, and pillar gridding can contribute to well bore spacing decisions. 


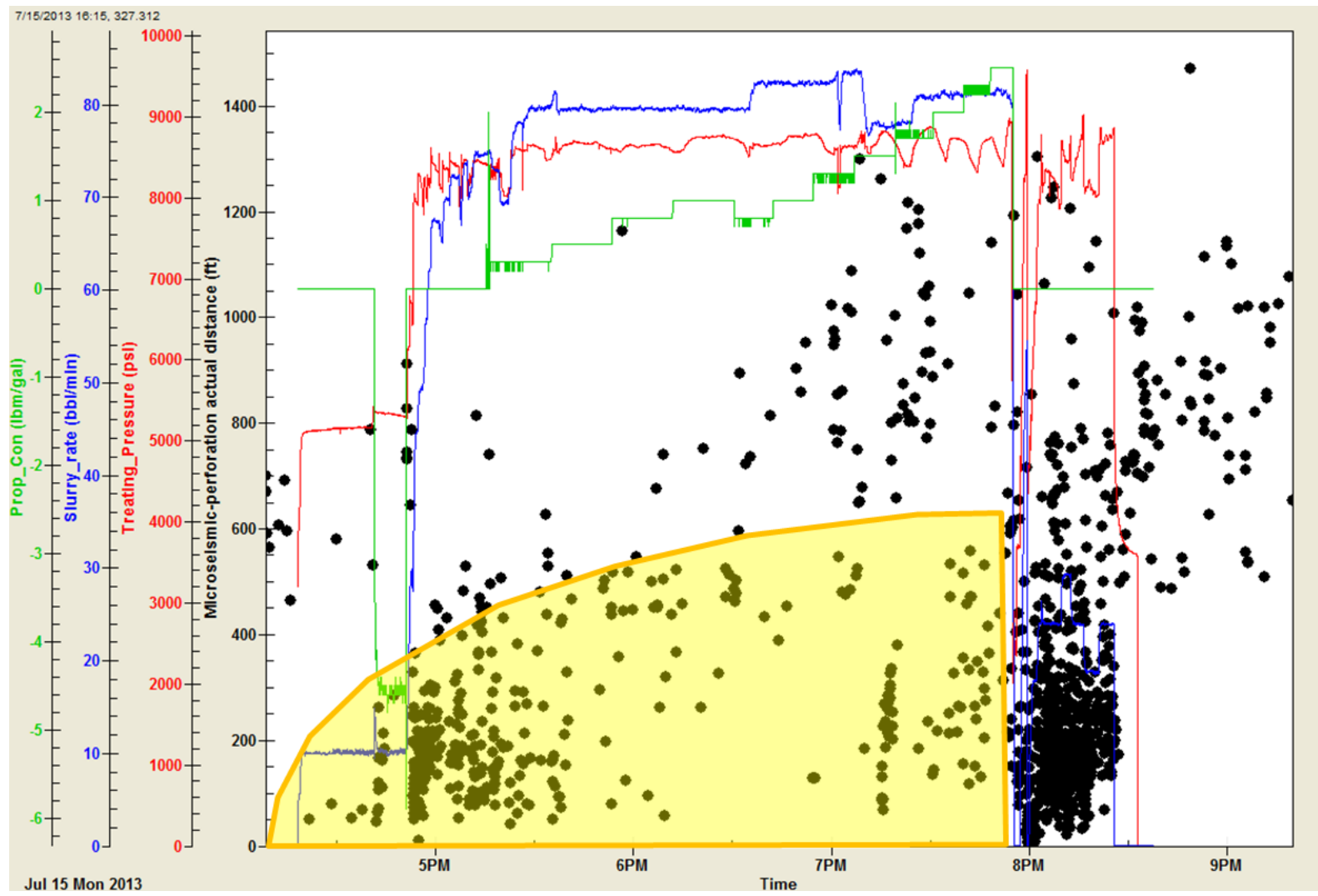

Figure 45. Stage $2 \mathrm{r}(\mathrm{t})$ plot with pumping data and microseismic data. Area highlighed in yellow represents the area of stimulated resevoir.
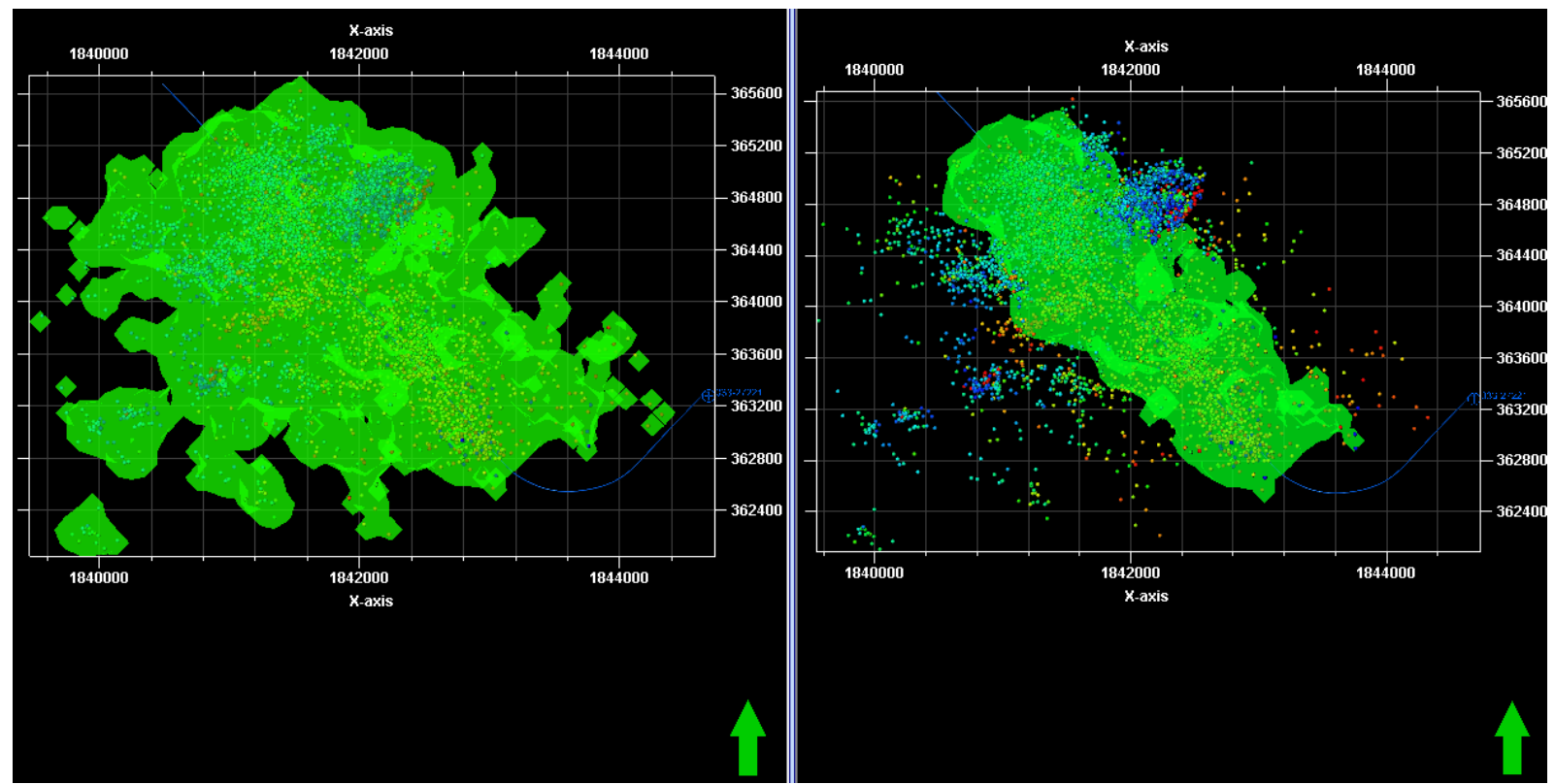

Figure 46. a) Volume of rock that experienced seismicity (730,028 acre-feet) 70 . b) Estimated stimulated reservoir volume from $\mathrm{r}(\mathrm{t})$ plots $(365,289$ acre-feet). 


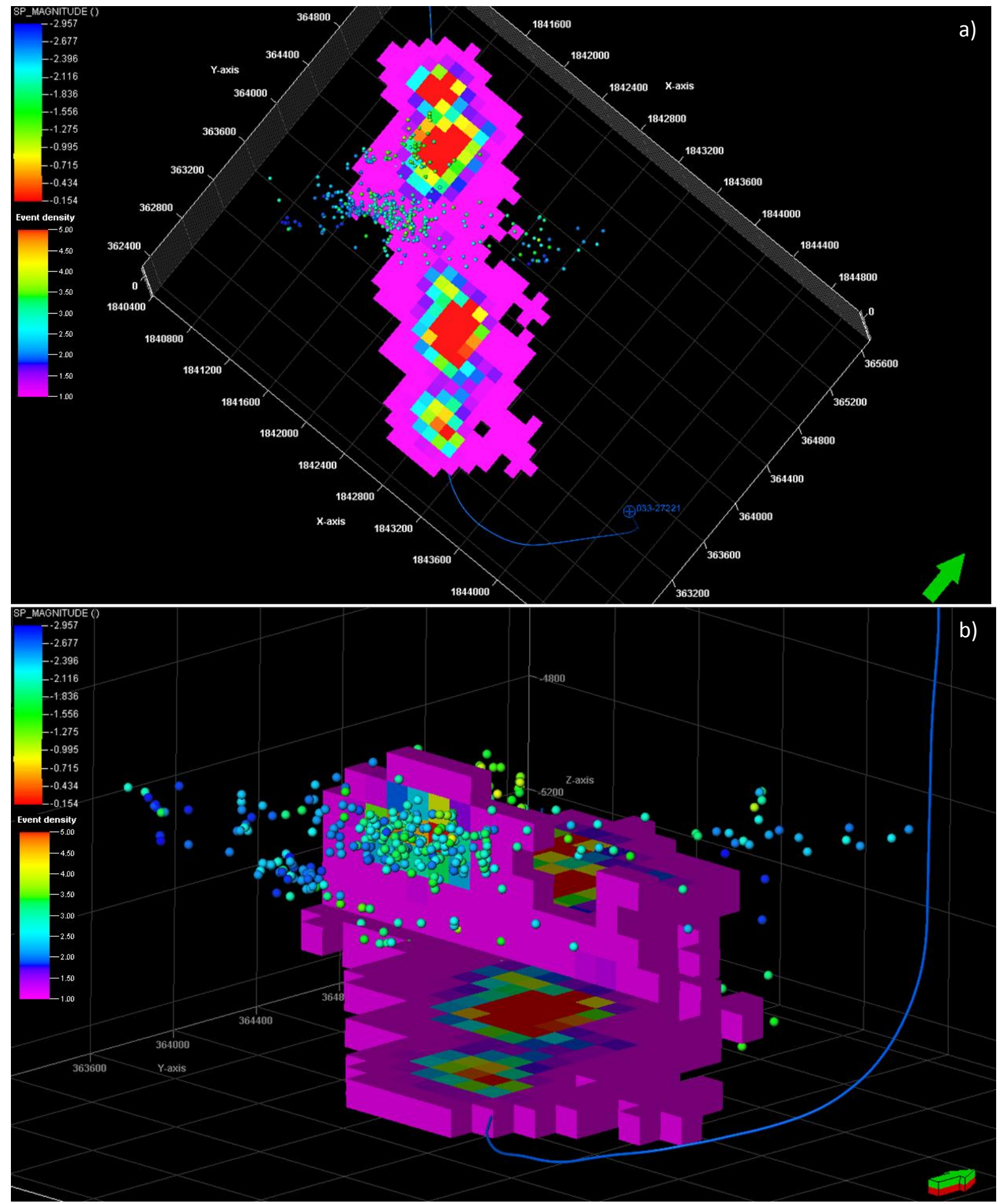

Figure 47. a) Map view of the pillar gridding event density within the ESRV with stage six microseismic events colored by magnitude showing increased event density on the southwest side of the well bore and decreased event density on the northeast side of the well bore. b) 3D view showing the cluster of events within the Moscow Formation. 


\subsubsection{B-value Analysis}

$\mathrm{R}(\mathrm{t})$ plots show the volume of rock stimulated; however fracture energy is used for all seismicity. Both fault and fracture related stages were observed from the b-value analysis. As mentioned stage two showed a sudden drop in pressure at the end of the stimulation (Figure 45). Prior to the pressure drop, the b-value was 1.37 indicating that seismicity was partially fault related (Figure 48). After stage two all of the events were partially fault related (Figure $49 \&$ Appendix C). A large strike-slip fault was interpreted parallel to the stimulation well about 1,000 ft. (305 m) away (Figure 50). Mapping stage two microseismic shows that a cluster of events occurred southwest of the perforation location. The cluster of microseismic events correlates to the fault damage zone within the Moscow Formation (Figure 51). This correlation is interpreted as a critically stressed fault damage zone that led to connectivity of a new fracture network to the interpreted fault. While the events that cluster around the fault are not within the ESRV, seismic energy focused toward this area is interpreted to reduce fracture efficiency near the well bore (Figure 51). Clustering of events within the Moscow Formation is evident for all stages. Seismicity is noticeably decreased above the Tully Limestone and below the Onondaga Limestone. Both limestone units provided a successful fracture barrier during stimulation (Figure 52). A bimodal distribution is present when plotting the microseismic events by depth. The peak to the right correlates to a depth within the Moscow Formation (Figure 53). The rock mechanic trends appear to control the behavior of fracture barriers and the bimodal frequency caused by the Moscow Formation. 


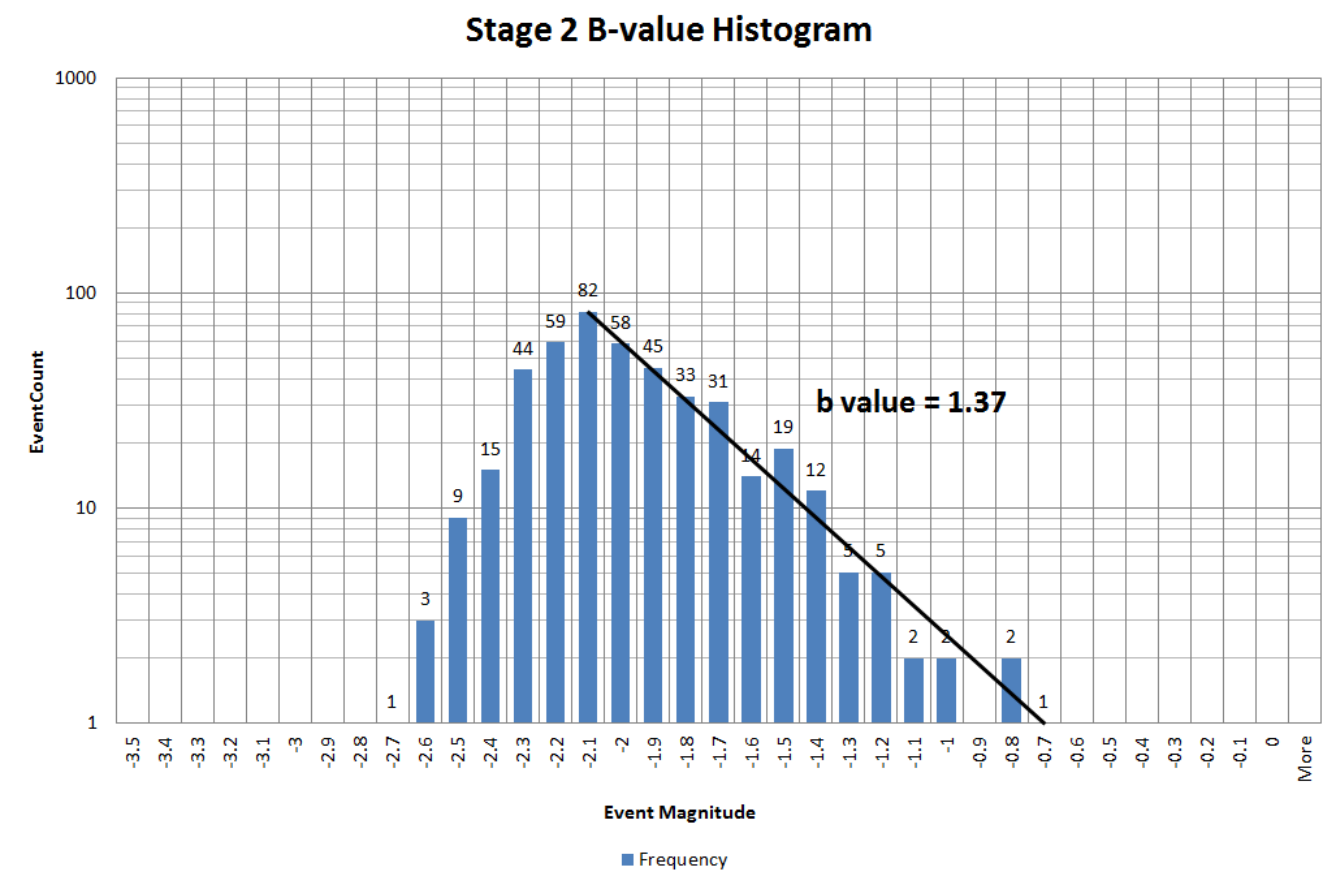

Figure 48. B-value histogram with event magnitude on the $x$-axis and event count on a logarithmic scale on the y axis. The slope of the right side of the histogram is the b-value (1.37). Any b-value 1.5 and below is considered partially fault related.

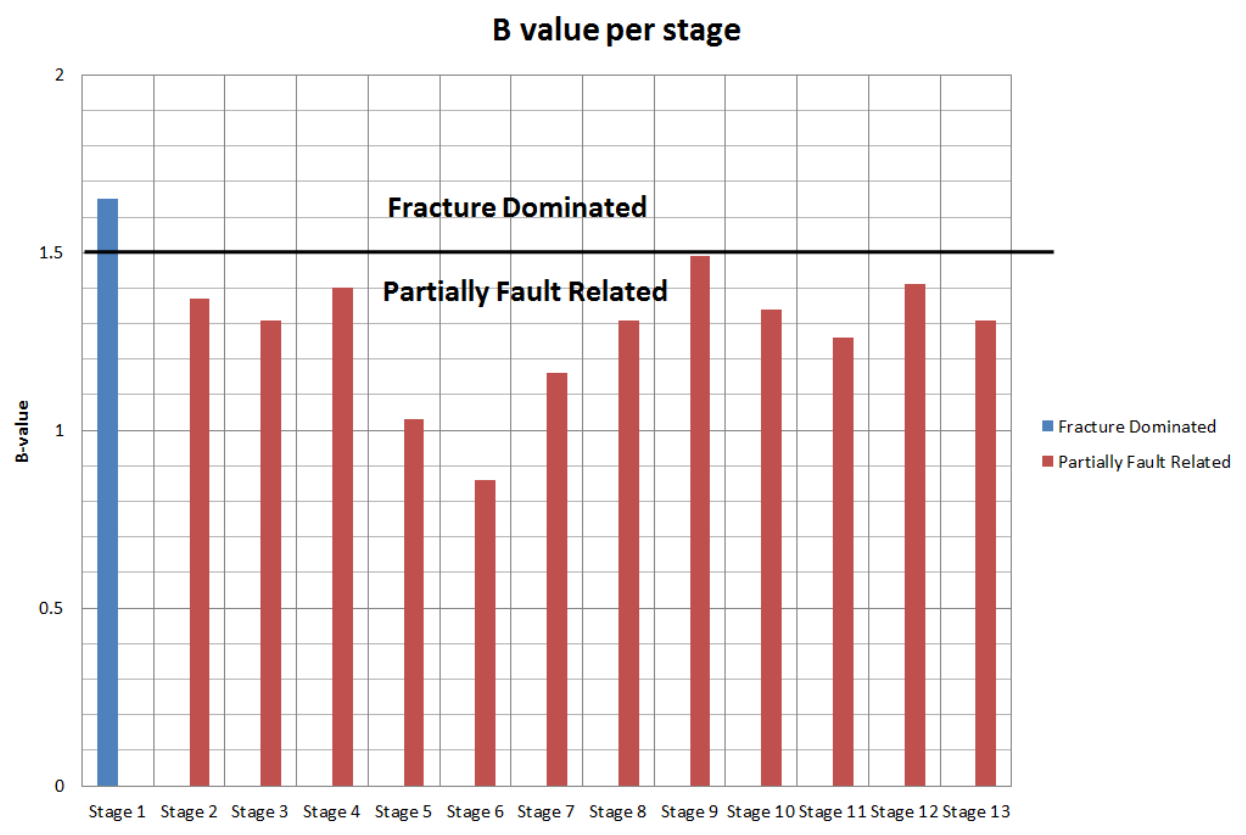

Figure 49. Bar chart showing the b-values for all thirteen stages. Hydraulic simulation was a zipper style frac where stage 1 is near the toe of the lateral and stage 13 is near the heal. The cut off between fracture dominated and partial fault connectivity events is 1.5 adopted from (Wessels et al., 2011). 


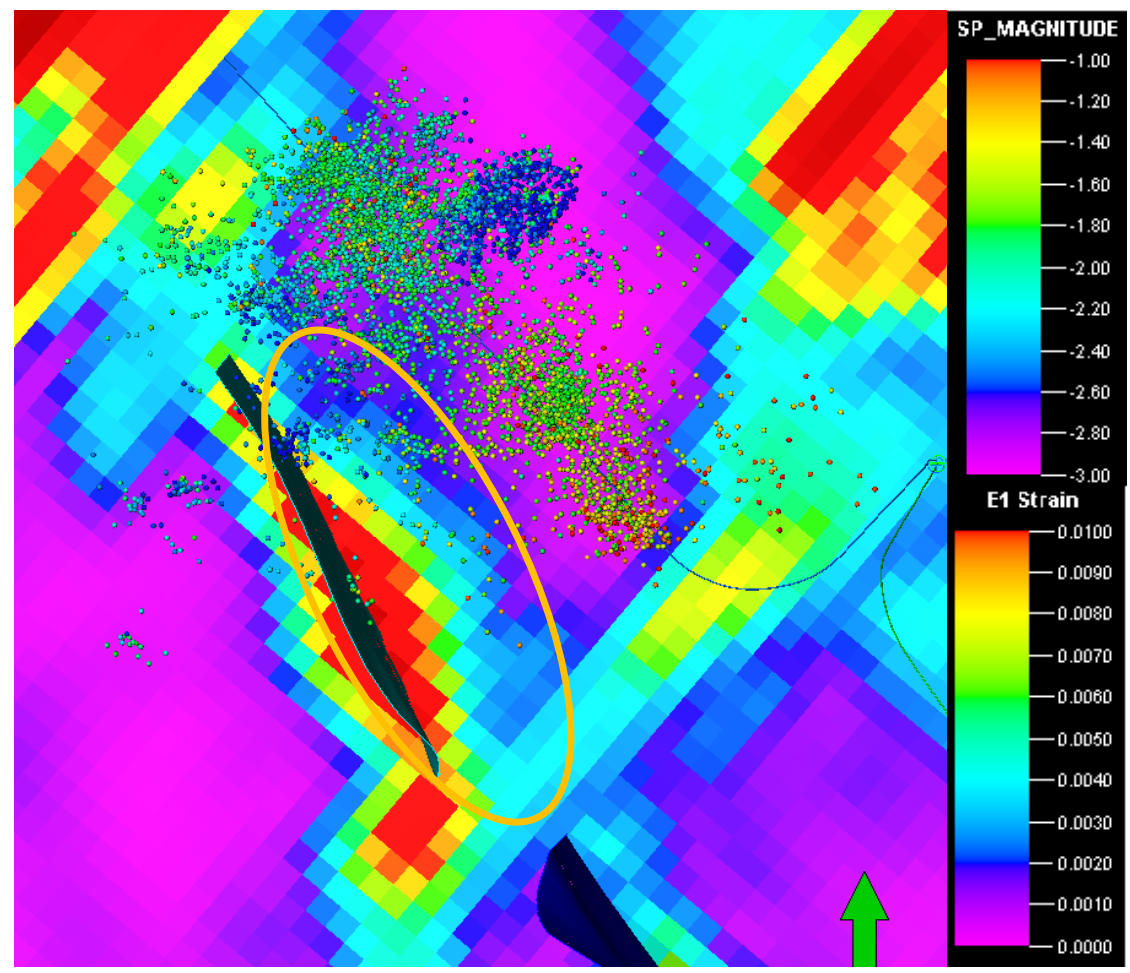

Figure 50. E1 Strain map within the Marcellus Formation. Highlighted in yellow is a crossstrike, strike-slip fault with close proximity to the stimulated well bore. Microseismic events are colored by magnitude.

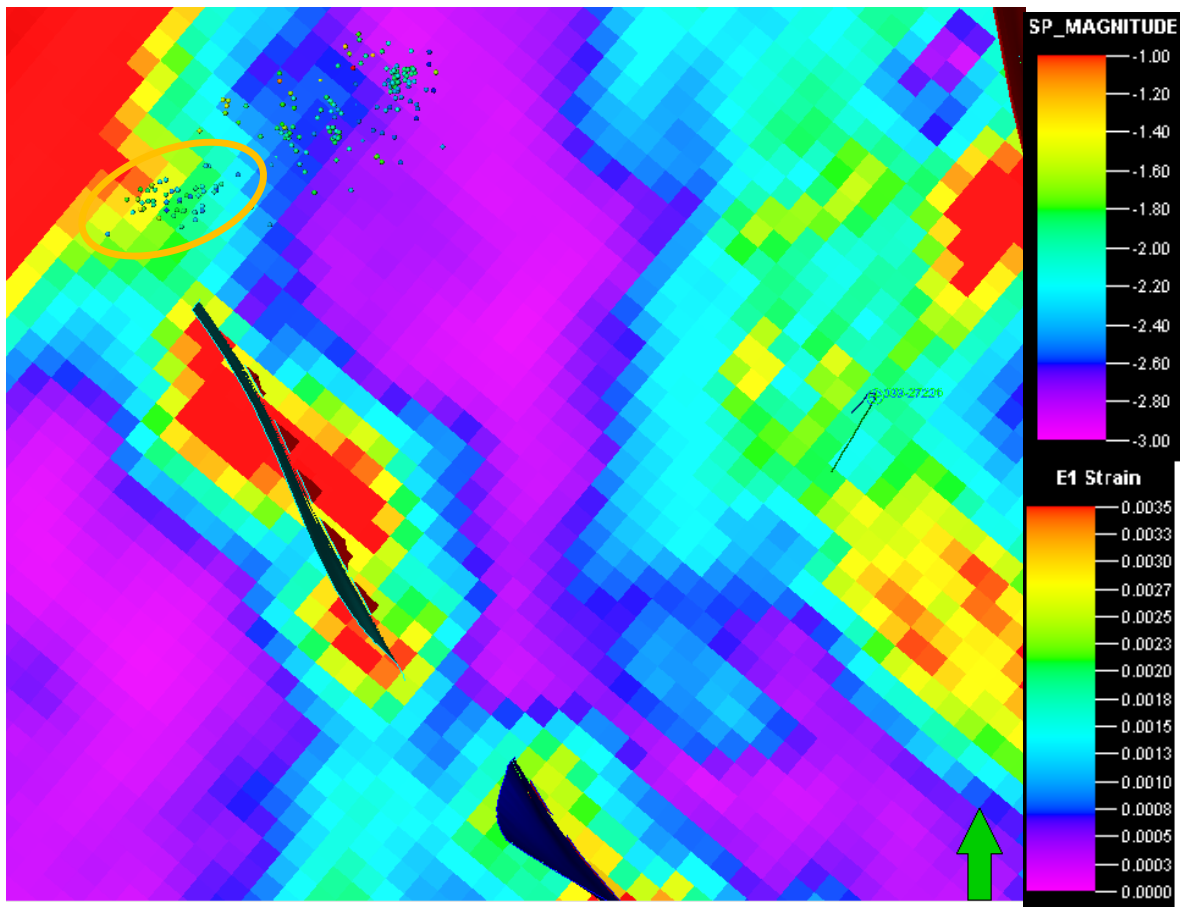

Figure 51. E1 strain map within the Moscow Formation. Highlighted by a yellow circle indicates the area stage 2 seismicity that lead the connection to a fracture network related to the fault. 


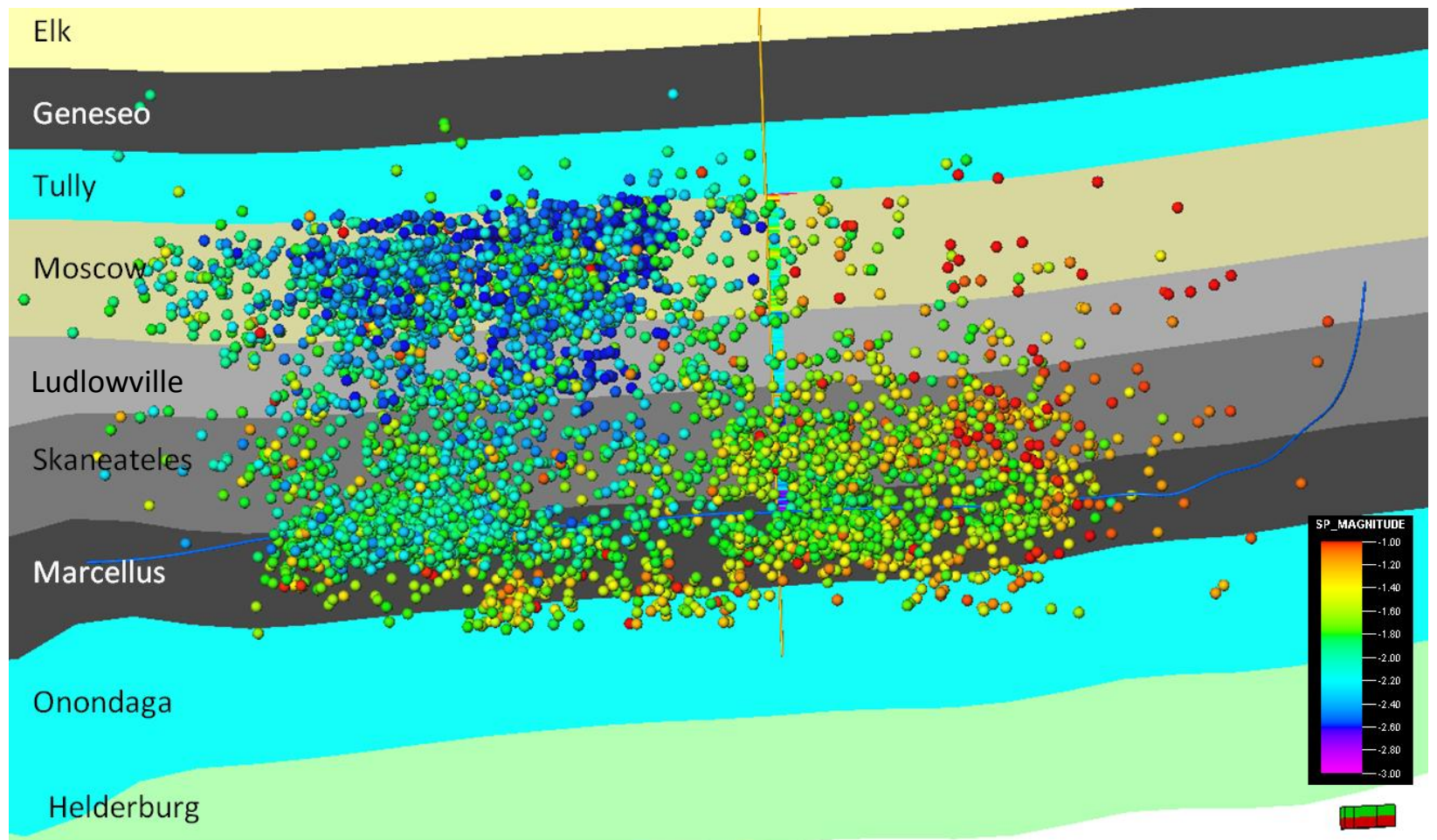

Figure 52. 3D view of all microseismic events colored by magnitude. Event density is greatest within the Marcellus and the Moscow Formation. The Tully and Onondaga Limestone provided effective fracture barriers.

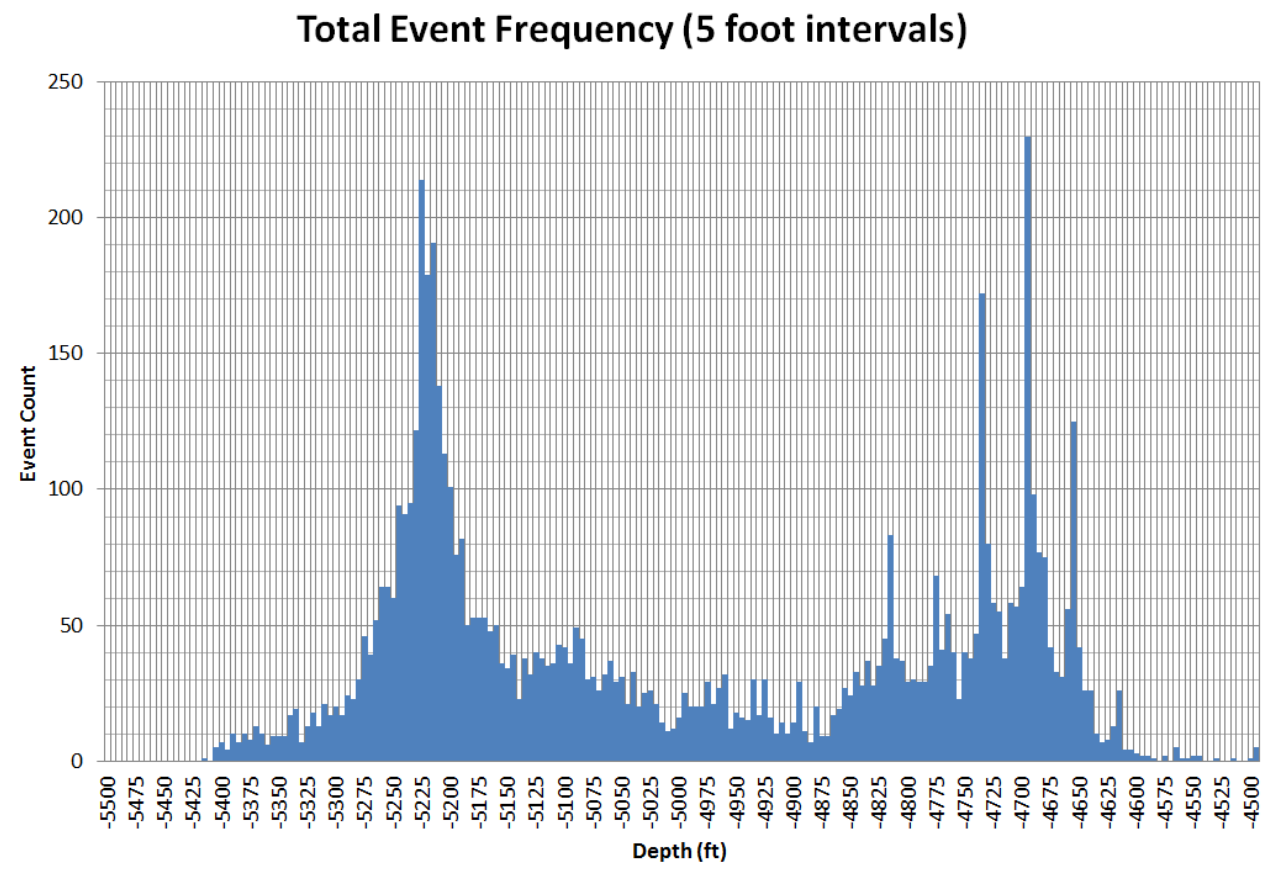

Figure 53. Bimodal frequency histogram of events plotted by depth. The peak to the left corresponds to the Marcellus Formation and the peak to the right corresponds to the Moscow Formation. 


\section{Mechanical Stratigraphy}

\subsection{Methodology}

Brittle behavior in shale is partly responsible for the fracture networks created at reservoir conditions. With the addition of triaxial strain testing in core, one can better understand general rock behavior under reservoir stimulation conditions. For this study, samples are held a constant confining pressure of 1,600 psi. Elastic deformation (strong, weak, stiff, or flexible) is any deformation that is recoverable (Fossen, 2012). Strong samples experienced failure at a deviatoric stress more than 15,000 psi and weak samples experienced failure at a deviatoric stress less than 15,000 psi (Figure 54). Stiff samples experienced failure at an axial strain less than 0.005 and flexible samples experienced failure at an axial strain more than 0.005 (Figure 54). In general, lithology can control deformation behavior. For example, limestone tends to act stiff and strong like steel, whereas clay-rich shale acts weak and flexible like Plexiglas. However, quartz-rich shale acts stiff and weak, and provides a more effective shale fracture zone. Contradictory, flexible samples (yellow and red in Figure 54) are not ideal for hydraulic stimulation (Figure 54). Triaxial strain testing also indicates general mechanical properties such as static Young's modulus and Poisson's ratio, which can be used to calculate static brittleness defined by the ratio of Young's Modulus to Poisson's ratio. Such tests provide a calibration for mechanical stratigraphy that can be interpreted from well logs and microseismic. 
Deviatory Stress, Strain for Triaxial Test

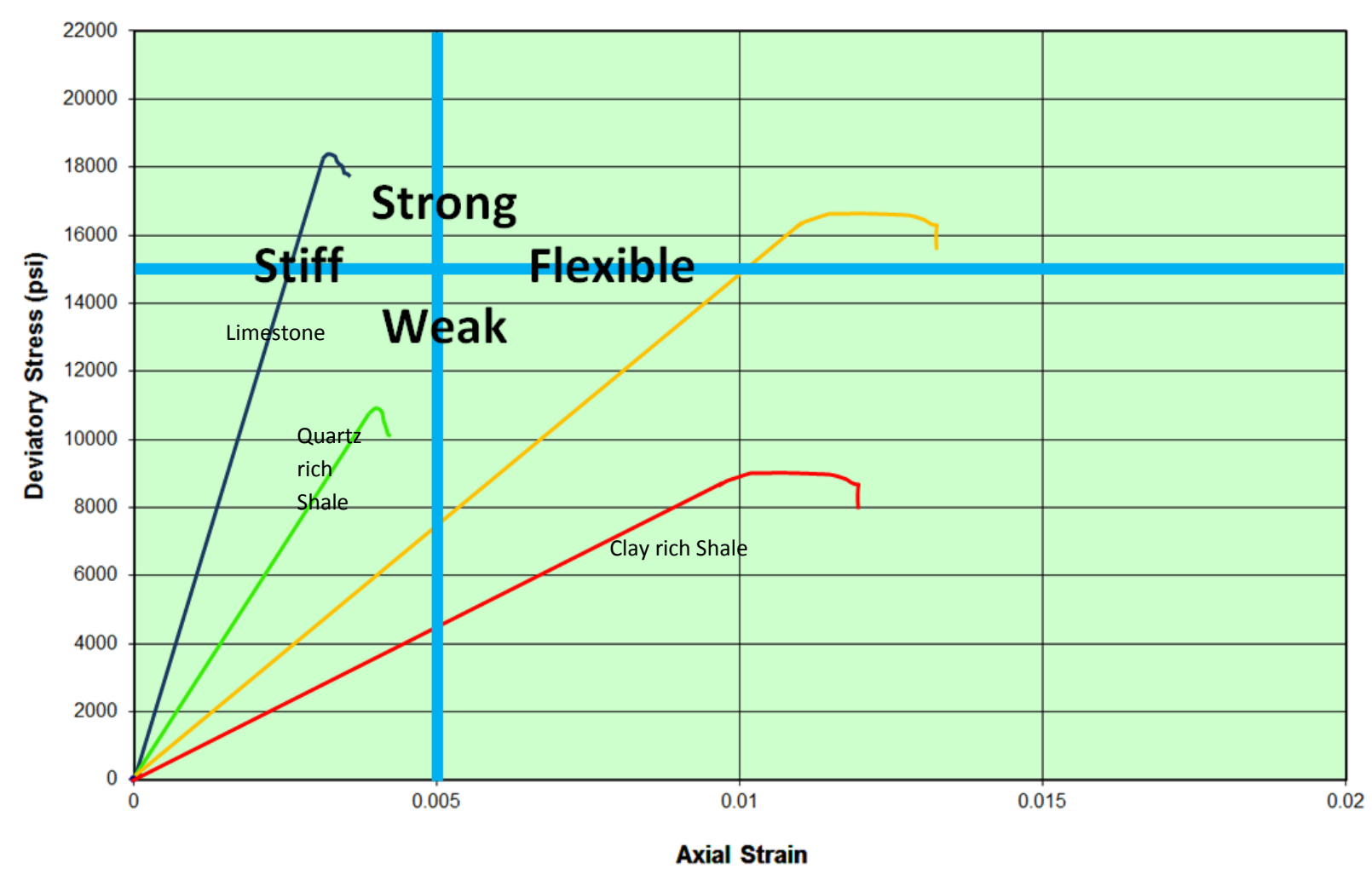

Figure 54. Example of triaxial strain test results for multiple lithologies. Modified from (Fox et al., 2013).

Brittleness in shale can also be calculated from well logs derived from dipole sonic and density logs. Brittleness from well logs is based on the relationship of Young's modulus and Poisson's ratio. Brittle shale will have high Young's modulus and low Poisson's ratio. Well log derived brittleness is a qualitative measurement because there is no unit of measurement for Poisson's ratio. The equations used for this study are found in Table 1 (Bateman, 2012). 


\begin{tabular}{|c|c|}
\hline $\begin{array}{c}\text { Poisson's Ratio } \\
\text { (unitless) }\end{array}$ & $v=\frac{\frac{1}{2}\left(V_{p}^{2}-V_{s}^{2}\right)-1}{\left(V_{p}^{2}-V_{s}^{2}\right)-1}$ \\
\hline $\begin{array}{c}\text { Shear Modulus } \\
\left(\text { psi } \times 10^{6}\right)\end{array}$ & $G=\frac{\boldsymbol{\rho}}{{V_{s}{ }_{s}{ }^{2}}^{2} \times\left(\mathbf{1 . 3 4} \times \mathbf{1 0}^{\mathbf{1 0}}\right)}$ \\
\hline $\begin{array}{c}\text { Young's Modulus } \\
\left(\text { psi } \times 10^{6}\right)\end{array}$ & $E=2 G \times(1+\boldsymbol{v})$ \\
\hline $\begin{array}{c}\text { Brittleness } \\
\text { (unitless) }\end{array}$ & Brittleness $=\frac{E}{\boldsymbol{v}}$ \\
\hline
\end{tabular}

Table 1. Equation for mechanical rock properties in well logs (Bateman, 2012).

Brittleness is also affected by quartz percentage and clay types. Spectral gamma-ray logs with Thorium, Potassium and Uranium percentages highlighted areas consisting of smectite or mixed-layer illite-smectite clays (Adams and Weaver, 1958). Strata with a thorium to potassium ratio of 3.5 or less are interpreted as illite rich and strata with a ratio of 3.5 or more are interpreted as rich in mixed layer clay (eg. illite and smectite). Smectite is a swelling clay that can hinder fracture potential within the rock. Illite is not a swelling clay. Also, as smectite experiences diagenesis to become illite a byproduct of quartz silt is left behind increasing the brittleness of the shale (Van De Kamp, 2008). XRD data for the core provided accurate clay percentages. 


\subsection{Results}

Triaxial strain analysis provided general rock properties of the Onondaga, Lower Marcellus and Upper Marcellus intervals. The data indicates that the Onondaga Limestone provides an effective barrier by behaving stiff and strong and requires $20,000 \mathrm{psi}$ of stress before brittle failure (Figures 54 and 55). Also, the Onondaga is interpreted as an effective fracture barrier due to exceptionally increased Young's modulus $\left(6.07 \mathrm{psi} \times 10^{6}\right)$ (Figure 55). The Lower Marcellus reacted strong and flexible (Figures 54 \& 55). Notice, the term flexible was chosen over the term ductile, because the term flexible refers to a type of elastic deformation, while ductile is a term used to describe plastic failure, which is not observed in the three samples. The flexible elastic deformation within the Lower Marcellus sample is not ideal for hydraulic stimulation.

After examining the XRD data some correlations to deformation style and lithology were made. The Upper Marcellus sample contained approximately $40 \%$ clay, while the Lower Marcellus contained approximately 10\% clay. The triaxial strain test indicates the Upper Marcellus is considered weak and flexible (Figures 54 and 55). In relation, the Upper Marcellus sample had decreased static Young's modulus, increased static Poison's ratio, and decreased brittleness (Figure 55). Therefore, increased clay content within the Upper Marcellus has been interpreted as a control for weak and flexible elastic deformation not ideal for hydraulic stimulation.

The Upper and Lower Marcellus samples have been interpreted to have substandard elastic deformation styles. However, the Lower Marcellus sample indicated a marginal increase 
in hydraulic potential.

Deviatory Stress, Strain for Triaxial Test

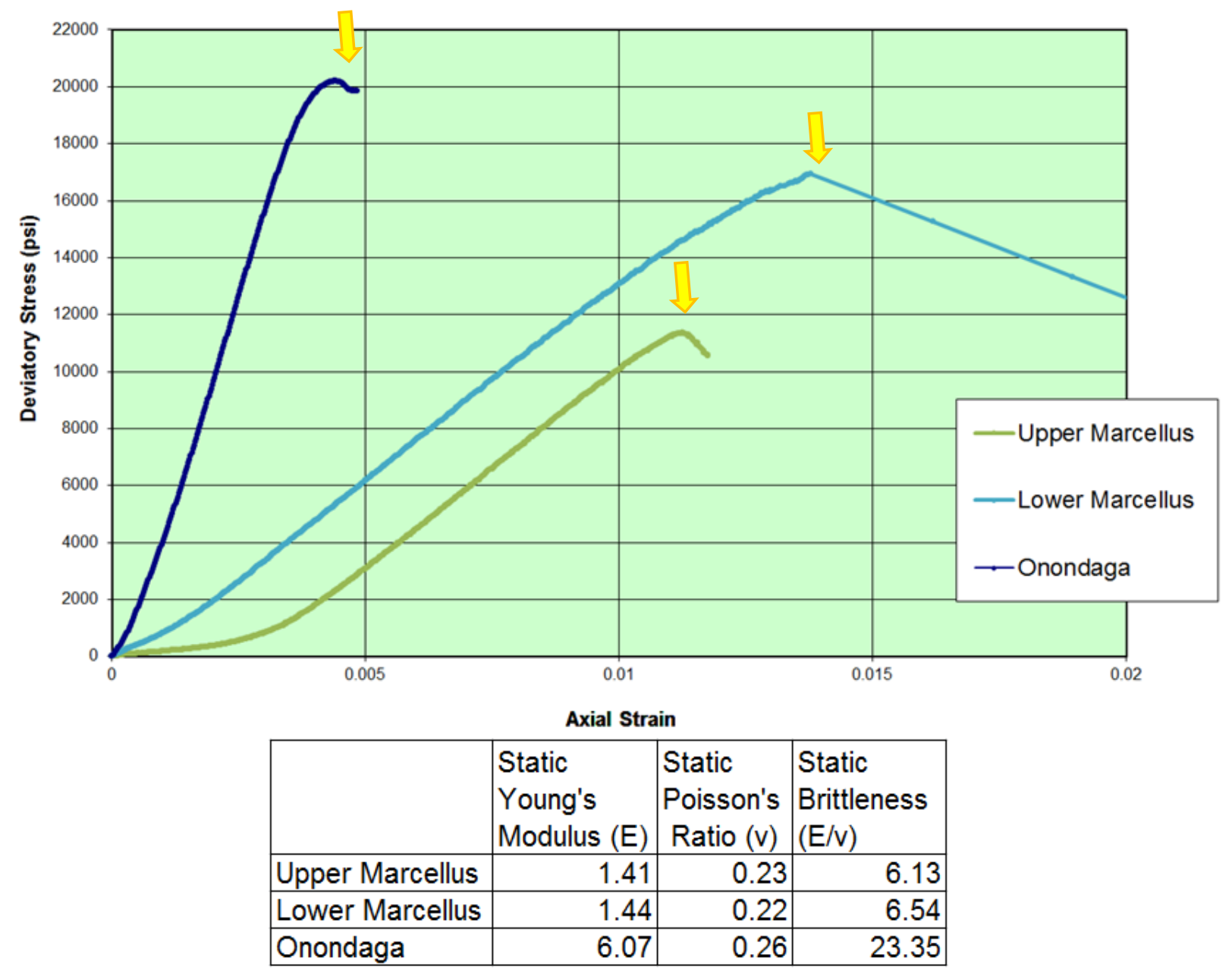

Figure 55. Triaxial strain test showing the relationship of stress to strain and the point of brittle deformation indicated by the yellow arrows. Static Young's modulus, Poisson's ratio and Brittleness are indicated below the chart.

Rock properties from well logs support the data from triaxial strain testing indicating that the shale Upper Marcellus is more ductile and the lowest portions of the Marcellus Formation are brittle (Figure 56). Rock properties from well logs for the Onondaga limestone in well 03326834 showed increased Young's modulus agreeing with the triaxial strain data. The Tully Limestone shows similar rock mechanics, which likely attributes to the fracture barrier 
effectiveness of these units. The calculated brittleness values for the Onondaga and Tully limestone units are increased however the increased Young's modulus allows these units to resist failure during stimulation. Another brittle shale zone is observed within the Moscow Formation.

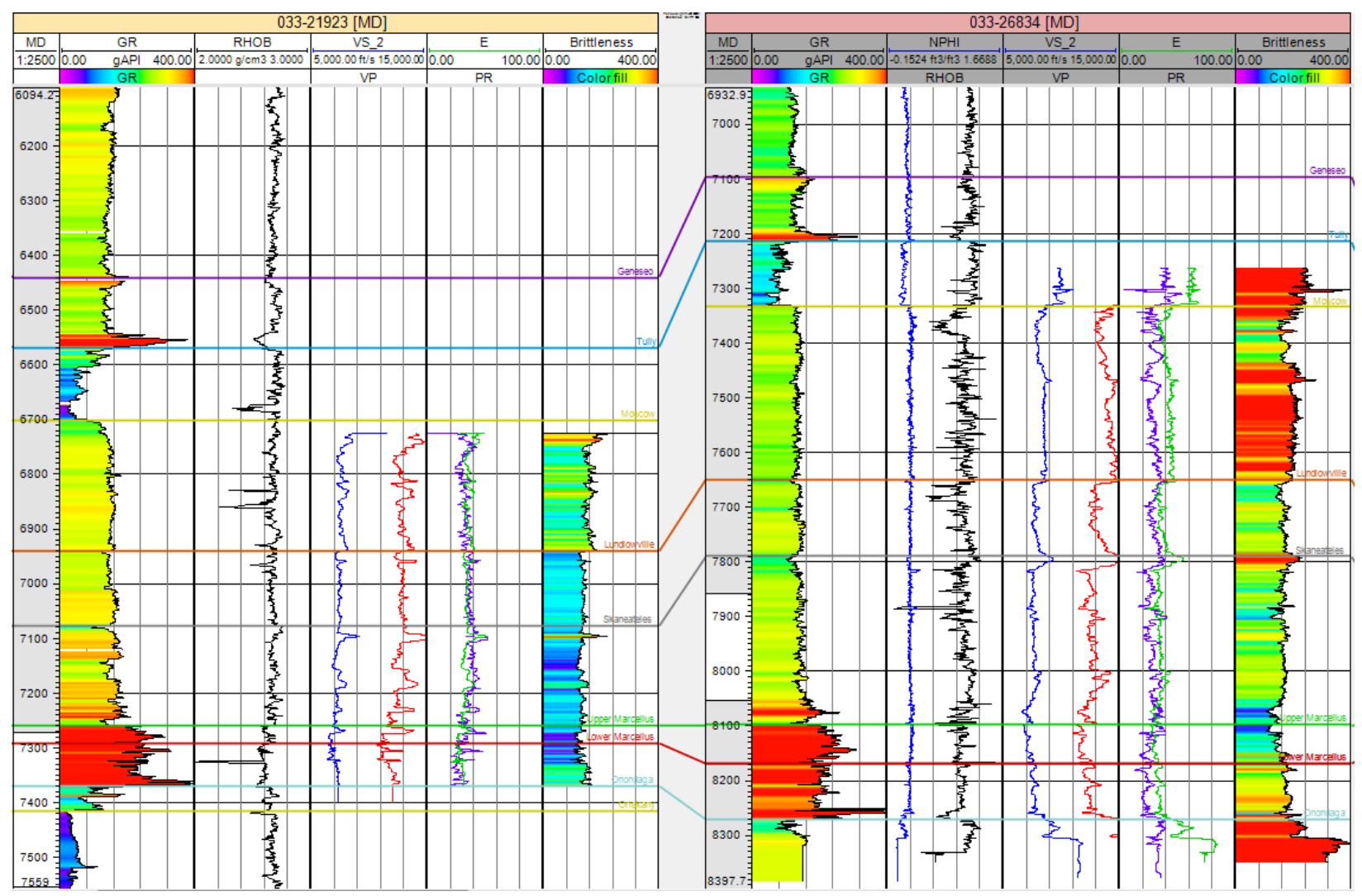

Figure 56. Brittleness curves derived from dipole sonic and density logs for wells 033-21923 and $033-26834$.

XRD data is not available for the Moscow Formation. However, thorium-potassium ratios show that the Moscow Formation has an Illite dominated clay type (Figure 57). While increased quartz is not observed within the data, increased quartz percentage can be assumed because as smectite transforms to illite during diagenesis a quartz silt byproduct results. Microseismic event frequency is increased in the Moscow Formation for well 033-27221. Therefore, three observations support the interpretation that the Moscow Formation is a zone of increased brittleness prone to failure during stimulation in Clearfield County: 
1. Increased brittleness values calculated from dipole sonic logs

2. Increased Illite clay type likely resulting in increased quartz percentage.

3. Increased microseismicity during the stimulation of well 033-27221.

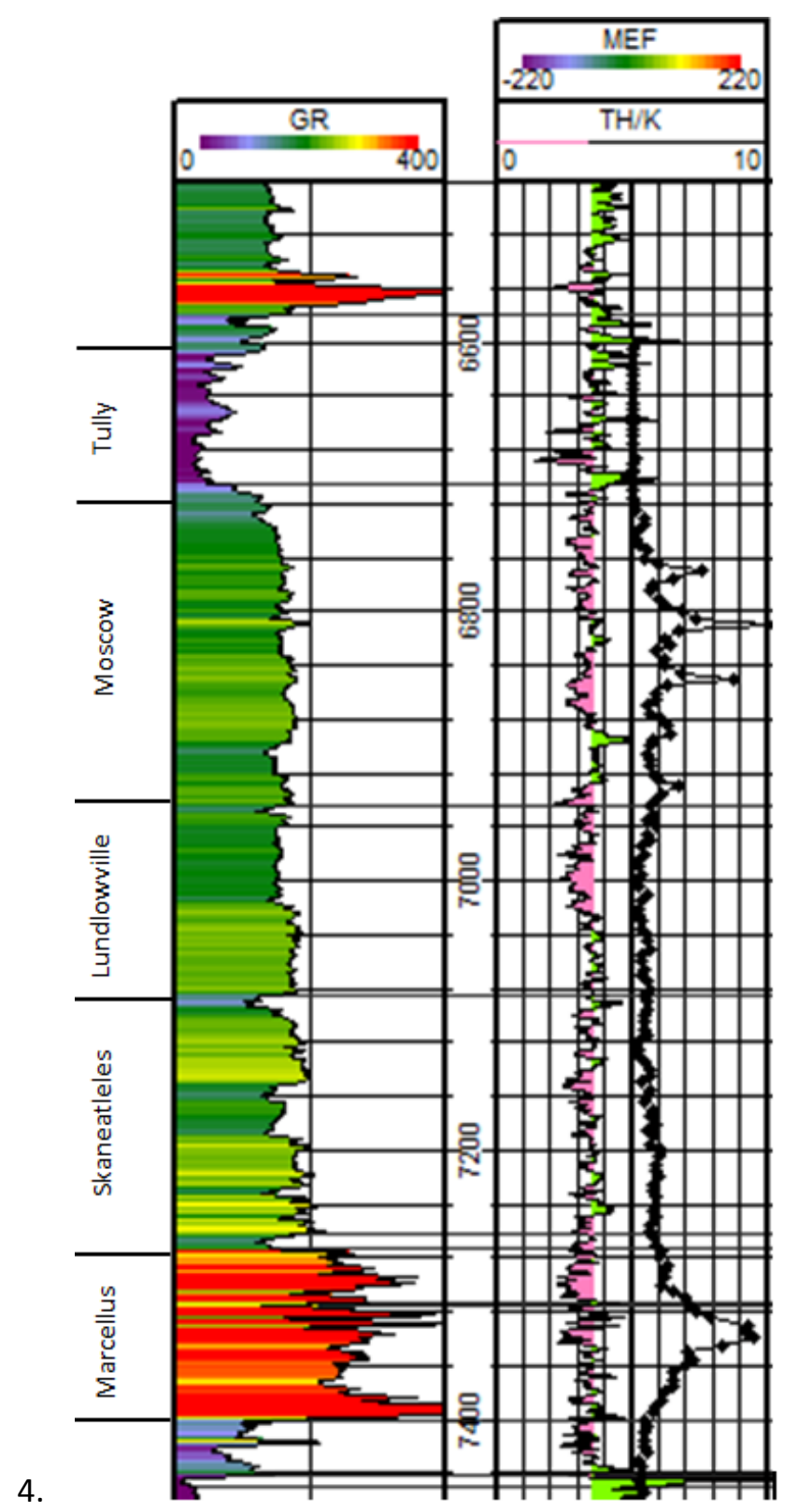

Figure 57. Well log within the fault model with a gamma-ray curve in track one and thorium/potassium curve (TH/K) and microseismic event frequency (MEF) in track two. A cut of 3.5 on the $\mathrm{TH} / \mathrm{K}$ curve highlights area illite rich (pink) and mixed layer smectite rich (green). 


\section{Conclusion}

The Marcellus Formation in Clearfield County, Pennsylvania is being explored by numerous oil and gas companies within the Appalachian basin. However, lower gas production in this area has discouraged drilling operations in this area. This research has investigated structural complexity, natural fracturing, and rock mechanics of a thirty-five square mile area within Clearfield County, Pennsylvania in order to highlight geologic factors that could attribute to lower gas production. The results from this research have shown the following:

1. By analyzing depth converted 3-D seismic the structure of the Middle Devonian within Clearfield County, Pennsylvania is complex due to kink band folding and large crossstrike, strike-slip faults similar to previous interpretations (Faill et al., 1989; Gillespie et al., 2013). The kink band modeled is preferred over the fore and back thrust model because the kink band geometry better explains pop-down structures and sub-seismic scale thickening.

2. Using a mass spring algorithm horizons from the fault model are restored so that principle strain magnitudes could be resolved using a constant strain triangle calculation. Evaluation of E1 and E1/E3 strain attributes with a geocellular model reveals that well 033-27221 (blue well) is drilled in close proximity to an enhanced naturally fractured area related to strike-slip faulting, while well 033-27206 (green well) is in close proximity to a moderately enhanced naturally fractured area related to passive folding.

3. Gas production in production (first 326 days) per foot of lateral for the well 033-27221 (blue well) is approximately half of well 033-27206 (green well). Therefore, enhanced fractures related to the cross-strike, strike-slip faults could potentially hinder hydraulic fracture treatment and gas production. 
4. Adopting the workflow by zone (Birkelo and Cieslik, 2012), microseismic analysis using $\mathrm{r}(\mathrm{t})$ plots shows that approximately a volume of 365,289 acre-feet and lateral distance from the well bore of $700 \mathrm{ft}(\sim 2133 \mathrm{~m})$ was effectively stimulated. During stimulation of stage 2 of the microseismic well, there was a sudden drop in pressure before stimulation was planned to terminate. Adopting the workflow by (Wessels et al., 2011) and establishing a cut off of 1.5 between fracture dominated events and partially fault related events, the b-value analysis shows that seismicity during stage 2 was partially fault related and that the remaining eleven stages were partially fault related. Comparing event location to the geomechanical model revealed stage two stimulation provided a connection to a strike-slip fault damage zone. This connectivity could have potentially reactivated a preexisting fracture network related to the fault providing a low pressure zone for the subsequent stages where fracture energy was dissipated.

5. The Moscow Formation was a zone of increased seismicity, while the Tully and Onondaga Limestone assisted in fracture containment.

6. By analyzing triaxial strain data, rock properties from dipole sonic and density logs, spectral gamma ray logs, and XRD data the Lower Marcellus and Moscow formations have been interpreted as zones of increased hydraulic stimulation potential. 


\section{References}

Adams, J.A.S. and Weaver, C. E., 1958, Thorium and uranium ratios as indications of sedimentary process: Example of concept of geochemical facies; American Association of Petroleum Geologists Bulletin, v. 42, p. 387-430.

Bateman, R., 2012, Openhole Log Analysis and Formation Evaluation: Richardson, TX, Society of Petroleum Engineers, p. 653.

Becker, T., W. Thomas, and G. Gehrels, 2006, Linking Late Paleozoic Sedimentary Provenance in the Appalchian Basin to the History of Alleghanian Deformation: American Journal of Science, v. 306, p. 777-798.

Birkelo, B., and K. Cieslik, 2012, Microseismic data illuminate fractures in the Montney: Spectraseis White Paper, v. August 16, 2012, p. 1 -5.

Bridge, Josiah, 1955, Diaconformity between Lower and Middle Ordovician series at DougLas Lake, Tennessee: Geological Society of America Bulletin, v. 66. p. $725 \cdot 730$.

Boswell, R., B. Thomas, B. Hussing, T. Murin, A. Donaldson, 1996a, Play Dbs: Upper Devonian Bradford Sandstones and Siltstones, in J. Roen and B. Walker, ed., The Atlas of Major Appalachian Gas Plays, p. 70 - 76.

Boyce, M., 2010, Sub-Surface Stratigraphy and Petrophysical Analysis of the Middle Devonian interval of the Central Appalachian Basin; West Virginia and Southwest Pennsylvania, PHD Dissertation, West Virginia University, Morgantown, p. 146.

Boswell, R., R. Heim, G. Wrighthouse, A. Donaldson, 1996b, Play Dvs: Upper Devonian Venango Sandstones and Siltsones, in J. Roen and B. Walker, ed., The Atlas of Major Appalachian Gas Plays, p. 63 - 69.

Chaveste, A., Z. Zhao, S. Altan, and J. Gaisner, 2013, Robust rock properties through PP-PS processing and interpretation-Marcellus Shale.

Chopra, S., R. Sharma, and K. Marfurt, 2014, Shale Gas Reservoir Charcertization Workflows: Search and Discovery Article \#41266.

Cotter, Edward, 1983, Shelf, paralic, and fluvial environments and eustatic sea-level fluctuations in the origin of the Tuscarora Formation (Lower Silurian) of central Pennsylvania: Journal of Sedimentary Petrology, v. 53, no. I, p. 25.49.

De Witt, W., 1993, Principal oil and gas plays in the Appalachian basin (Province 131): U.S. Geological Survey Bulletin 18391, p. 11·137.

Dershowitz, W., and H. Herda, 1992, Interpretation of fracture spacing and intensity: Rock Mechanics, p. 757-766. 
Donaldson, A., R. Boswell, X. Zou, L. Cavallo, R. Heim, and M. Canich, 1996, Play Des: Upper Devonian Elk Sandstones and Siltstones, in J. Roen and B. Walker, ed., The Atlas of Major Appalachian Gas Plays, p. 77 - 85.

Engelder, T., G. G. Lash, and R. S. Uzcategui 2009, Joint sets that enhance production from Middle and Upper Devonian gas shales of the Appalachian Basin: AAPG Bulletin, v. 93, p. 857-889.

Eshkalak, M., S. Mohaghegh, and S. Esmaili 2013, Synthetic, Geomechanical Logs for Marcellus Shale:SPE-163690-MS, p. 1- 16.

Ettensohn, F.R., 1987, Rates of relative plate motion during the Acadian orogeny based on the spatial distribution of black shales. J. Geol. 95: 572-582.

Faill, R.T., 1969, Kink band structures in the Valley and Ridge Province, Central Pennsylvania: GSA Bulletin, v. 80, p. 2539-2550.

Faill, R.T., 1973, Kink band folding, Valley and Ridge Province, Pennsylvania: GA Bulletin, v. 84 , p. $1289-1314$.

Faill, R. T., 1985, The Acadian orogeny and the Catskill delta, in Woodrow, D.L., and Secon, W.D., eds., The Catskill Delta: Geological Society of America Special Paper 201, p. 1537.

Faill, R.T., A. D. Glover, and J. H. Way, 1989, Geology and Mineral Reseourses of the Blandburg, Tipton, Altoona, and Bellwood Quadrangles, Blair, Cambria, Clearfield, and Centre Counties, Pennsylvania: Pennsylvania Geological Survey Journal, v. 4, p. 1-209.

Faill, R. T., 1997a, A Geologic History of the North-Central Appalachians. Part I. Orogenies from the Mesopreterozoic Through the Taconic: America Journal of Science, v. 297, p. 551-619.

Faill, R. T., 1997b, A Geologic History of the North-Central Appalachians, Part 2: The Appalachian Basin from the Silurian through the Carboniferous: American Journal of Science, v. 297, p. 729-761.

Faill, R. T., 1998, A Geologic History of the North-Central Appalachians, Part 3. The Alleghany Orogeny: American Journal of Science, v. 298, p. 131-179.

Fossen H. 2010, Structural Geology: Cambridge, University Press, 463 p.

Gillespie, P. S. Wessels, D. Lynch and J. van Hagen, 2013, 3-D Seismic and Geosteering Analysis Reveals the Structural Style of the Appalachian Plateau: Search and Discovery Article \#41197. 
Gray D., P. Anderson, J. Logel, F. Delbecq, D. Schmidt, and R. Schmid, 2012, Estimation of stress and geomechanical properties using 3D seismic data: First Break, v. 30, p. 59 -68.

Harris, A.G., and Repetski, J.E., 1983, Conodonts document continuous to intermittent deposition \&Cl"088 the Lower-Middle Ordovician boundary; northern Virginia to Bellefont, Pennsylvania labs): Virginia Journal of Science, v. 34, p. 172.

Harrison, M. J., S. Marshak, and J. H. McBride, 2004, The Lackawanna synclinorium, Pennsylvania: A salt-collapse structure partially modified by thin-skinned folding. GSA Bulletin, v. 116 p1499-1514.

Hatcher, R. D., 2009, The Appalachian orogen: A brief summary. From Rodinia to Pangea: The Lithotectonic Recod of the Appalachian Region: Geological Society of America Memoir, v. 206, p. 1-19.

Hayward, J., 2012, Zircon Geochronology of Ash Beds in the Marcellus Shale of the Appalachian Basin, Master's Thesis, West Virginia University, Morgantown, p. 96.

Heckel, P., 1969, Devonian Tully Limestone in Pennsylvania and Comparison to Type Tully Limestone in New York: Pennsylvania Geological Survey Bulletin, v. 60, p. 1-33.

Jacobi, R., J. Starr, D. Jackson, T. Warner, and C. Eckert, 2013, Acadian Sliding: Anatomy of Styles for Gravitational Fault Development and Hydrocarbon Migration in the Western Appalachian Foreland Basin of Pennsylvania and West Virginia: Search and Discovery Article \#41126. p. 1-9.

Kanamori, H., and D. Anderson, 1975, Theoretical Basis of some Empirical relations in seismology:Bulliten of the Seismological Society of America, v. 65, p. 1073-1095.

Kim, Y., and D. Sanderson, 2005, The relationship between displacement and length of faults: a review: Earth-Science Reviews, v. 68, p. 317 - 334.

Kulander, C. and R. Ryder, 2005, Regional Seismic Lines across the Rome Trough and Allegheny Plateau of Northern West Virginia, Western Maryland, and Southwestern Pennsylvania: USGS Geologic Investigations Series Map I-2791.

Loucks, R. G., R. M. Reed, S. C. Ruppel, and U. Hammes, 2012, Spectrum of pore types and networks in mudrocks and a descriptive classification for matrix-related mudrock pores: AAPG Bulletin, v. 96, no. 6, p. 1071-1098.

Marshak, S., 2010, Essentials of Geology, 3rd Edition: W. W. Norton \& Company Limited, 648 p.

Milici, R.C.,1973, The stratigraphy of Knox County, Tennessee, in Geology of Knox County, Tennessee: Tennessee Division of Geology, Bulletin 70, p. 9.24. 
Milici, R.C., 1996, Stratigraphic History of the Appalachian Basin, in J. Roen and B. Walker, ed., The Atlas of Major Appalachian Gas Plays, p. 4-7.

Mitra, S., 1990, Fault-Propagation Folds: Geometry, Kinematic Evolution, and Hyrdocarbon Traps: AAPG Bulletin, v. 74, p. 921-945.

Mussman, W.J., and Read, J.F., 1986, Sedimentology and development of a passive to convergent margin unconformity: Middle Ordovician Knox unconformity, Virginia Appalachians: Geological Society of America Bulletin, v. 97, no. 3, p. 282.295.

Rickman, R., Mullen, M., Petre, J., Grieser, W., \& Kundert, D. (2008). A Practical Use of Shale Petrophysics for Stimulation Design Optimization: All Shale Plays Are Not Clones of the Barnett Shale. Proceedings of SPE Annual Technical Conference and Exhibition, Denver, USA, 21-24 September 2008. SPE 115258.

Roberts, E., 2013, Structure Segmentation and Transfer Faults in the Marcellus Shale, Clearfield County, PA: Implications for Gas Recovery Efficiency and risk Assessment in Central Appalachian Basin Using 3D Seismic Attribute Analysis, Master's Thesis, West Virginia University, Morgantown, p. 94.

Rodgers, J., 1971, The Taconic orogeny: Geological Society of America Bulletin, v. 82, p.1141-1178.

Scanlin, M., and T. Engelder, 2003, The Basement Versus the No-Basement Hypotheses for Folding within the Appalachian Plateau Detachment Sheet: American Journal of Science, v. 303 , p. $519-563$.

Shanmugam, G., and Lash, G.G., 1982, Analogous tectonic evolution of the Ordovician foredeeps, southern and central Appalachians: Geology, v. 10, p. 562-566.

Smosna, R. and Patchen, D. G., 1991, Ordovician Limestone and Shale in the Central Appalachian Basin: Early Sedimentary Response to Plate Collision, SEPM Core Workshop No. 15, Dallas, April 7, 1991.

Slattery, W., 1993, Sequence Stratigraphy and Depositional Framework of the Upper Middle Devonian Mahantango Formation in Pennsylvania and New York, Doctoral Disertation, The City University of New York, New York, p. 149.

Van De Kamp, P., 2008, Smectite-Illite-Muscovite Transformations, Quartz dissolution, and Silica Release in Shales: Clays and Clay Minerals, v. 56, n. 1, p. 66-81.

Wang, G. Black Shale Lithofacies Prediction and Distribution Pattern Analysis of Middle Devonian Marceulls Shale in the Appalachian Basin, Northeastern U.S.A. PHD Dissertation, West Virginia University, Morgantown, p. 216. 
Wehr, F., and Glover, L., Ill, 1985, Stratigraphy and tectonics of the Virginia-North Carolina Blue Ridge: Evolution of a late Proterozoic Early Paleozoic hinge zone: Geological Society of America Bulletin, v. 96, no. 3, p. 285.295.

Wessels, S., M. Kratz, A. De La Pena, 2011, Identifying fault activation during dydraulic stimulation in the Barnett shale: source mechanisms, b values, and energy release analyses of microseismicity: 2009 SEG Annual Meeting, San Antonio, Texas, p. 1463 1467.

Whisonant, R.C., 1977, Lower Silurian Tuscarora (Clinch) dispersal patterns in western Virginia: Geological Society of America Bulletin, v. 88, p. 215-220.

Whitmeyer, S and K. Karlstorm, 2007, Tectonic Model for the Proterzoic growth of North America: Geosphere, v. 3, no. 4, p. 220-259.

Willis, B., 1893, Mechanics of Appalachian Structure: U.S.Geological Survey Annual Report, v. 13 , p. $217-281$.

Wise, D., 1970, Multiple deformation, geosynclinals transitions, and the Martic problem in Pennsylvania, in Fisher, G., Petijohn, F., and Rice, C., ed., Paleoenvironmental and tectonic controls in coal-forming basins of the United States: Geological Society of America Special Paper 210, p. 31-47.

Yanni, A., 2010, Subsurface Stratigraphy and Petrophysical Analysis of the Middle Devonian Interval Including the Marcellus Shale, of the Central Appalachian Basin; Northwestern Pennsylvania, Master's Thesis, West Virginia University, Morgantown, p. 60.

Yeakel, L.S., 1962, Tuscarora, Juniata, and Bald Eagle paleocurrents and paleogeography in the central Appalachians: Geological Society of America Bulletin, v, 73, p. 1515-1540.

Zhao, M., and R. Jacobi, Formation of regional cross-fold joints in the northern Appalachian Plateau: Journal of Structural Geology, v. 19, n. 6, p. 817-834.

Zagorski, W., G. Wrightstone, and D. Bowman, 2012, The Appalachian Basin Marcellus Gas Play: Its History of Development, Geologic Controls on Production, and Future Potential as a World-class Reservoir: AAPG Memoir, v. 97, p. 172-200. 


\section{Appendix A. Velocity Model Results}

\begin{tabular}{|c|c|c|c|c|c|c|}
\hline $\begin{array}{l}\text { Velocity Model } \\
\text { Results }\end{array}$ & & & & & & \\
\hline \multirow[t]{15}{*}{ Elk 2 Surface } & Well & $\mathrm{X}$-value & Y-value & Z-value & $\begin{array}{l}\text { Horizon } \\
\text { After }\end{array}$ & $\begin{array}{l}\text { Difference } \\
\text { After }\end{array}$ \\
\hline & 033-26874 & 1802530 & 285405.2 & -4631.96 & Outside & \\
\hline & 033-26848 & 1819027 & 345521.6 & -3663.29 & Outside & \\
\hline & 033-21634 & 1845980 & 366800.9 & -3467.23 & -3456.32 & -10.91 \\
\hline & 033-26834 & 1913583 & 318024.8 & -4475.6 & Outside & \\
\hline & 033-21396 & 1846168 & 364719.3 & -3472.79 & -3437.53 & -35.26 \\
\hline & 033-22280 & 1848508 & 364605.9 & -3517.15 & -3504.64 & -12.5 \\
\hline & 033-22015 & 1840609 & 363156.3 & -3504.68 & -3533.98 & 29.3 \\
\hline & 033-21739 & 1843826 & 366665.6 & -3472.82 & -3496.8 & 23.98 \\
\hline & 033-21923 & 1842716 & 364443 & -3490.17 & -3515.4 & 25.23 \\
\hline & 033-22463 & 1840923 & 366484.4 & -3464.5 & -3519.23 & 54.73 \\
\hline & 033-22279 & 1848931 & 366672.8 & -3519.28 & -3468.3 & -50.98 \\
\hline & $033-22281$ & 1838625 & 361708.6 & -3542.12 & -3528.5 & -13.62 \\
\hline & 033-22014 & 1844411 & 363481 & -3492.62 & -3488.7 & -3.92 \\
\hline & 033-24080 & 1845669 & 368493.5 & -3480.81 & -3479.5 & -1.31 \\
\hline \multirow[t]{18}{*}{ Tully 2 Surface } & Well & $\mathrm{X}$-value & Y-value & Z-value & $\begin{array}{l}\text { Horizon } \\
\text { After }\end{array}$ & $\begin{array}{l}\text { Difference } \\
\text { After }\end{array}$ \\
\hline & $033-27221$ & 1844628 & 363282.8 & -4465.07 & -4386.99 & -78.08 \\
\hline & 033-26874 & 1802530 & 285405.2 & -5630.87 & Outside & \\
\hline & 033-26848 & 1819027 & 345521.6 & -4567.63 & Outside & \\
\hline & 033-21634 & 1845980 & 366800.9 & -4441.9 & -4339.19 & -102.7 \\
\hline & 033-26834 & 1913583 & 318024.8 & -5801.09 & Outside & \\
\hline & 033-21396 & 1846168 & 364719.3 & -4440.21 & -4308.56 & -131.65 \\
\hline & 033-22280 & 1848508 & 364605.9 & -4493.63 & -4425.88 & -67.75 \\
\hline & $033-22015$ & 1840609 & 363156.3 & -4472.4 & -4481.36 & 8.96 \\
\hline & 033-21739 & 1843826 & 366665.6 & -4435.51 & -4428.65 & -6.86 \\
\hline & 033-21923 & 1842716 & 364443 & -4457.06 & -4481.85 & 24.79 \\
\hline & 033-22463 & 1840923 & 366484.4 & -4435.13 & -4477.7 & 42.57 \\
\hline & 033-22279 & 1848931 & 366672.8 & -4492.43 & -4379.85 & -112.58 \\
\hline & $033-22281$ & 1838625 & 361708.6 & -4507.1 & -4470.21 & -36.9 \\
\hline & 033-22014 & 1844411 & 363481 & -4461.64 & -4408.16 & -53.48 \\
\hline & 033-24080 & 1845669 & 368493.5 & -4448.19 & -4352.75 & -95.44 \\
\hline & 033-22377 & 1832509 & 359313.3 & -4512.68 & Outside & \\
\hline & 033-27206 & 1844522 & 362995.3 & -4465.12 & -4401.15 & -63.97 \\
\hline
\end{tabular}




\begin{tabular}{|l|l|r|r|r|r|r|} 
& & & & & \\
\hline $\begin{array}{l}\text { Onondaga } \\
\text { Surface }\end{array}$ & Well & X-value & Y-value & Z-value & $\begin{array}{l}\text { Horizon } \\
\text { After }\end{array}$ & $\begin{array}{l}\text { Difference } \\
\text { After }\end{array}$ \\
\hline & $033-26874$ & 1802530 & 285405.2 & -6487.48 & Outside & \\
\hline & $033-21634$ & 1845980 & 366800.9 & -5267.34 & -5225.23 & -42.11 \\
\hline & $033-26834$ & 1913583 & 318024.8 & -6857.21 & Outside & \\
\hline & $033-21396$ & 1846168 & 364719.3 & -5239.17 & -5136.87 & -102.3 \\
\hline & $033-22280$ & 1848508 & 364605.9 & -5287.17 & -5243.59 & -43.58 \\
\hline & $033-22015$ & 1840609 & 363156.3 & -5263.76 & -5338.66 & 74.9 \\
\hline & $033-21739$ & 1843826 & 366665.6 & -5221.88 & -5263.03 & 41.15 \\
\hline & $033-21923$ & 1842716 & 364443 & -5259.28 & -5341.03 & 81.75 \\
\hline & $033-22463$ & 1840923 & 366484.4 & -5280.1 & -5323.02 & 42.92 \\
\hline & $033-22279$ & 1848931 & 366672.8 & -5287.48 & -5194.19 & -93.29 \\
\hline & $033-22281$ & 1838625 & 361708.6 & -5293.92 & -5330.64 & 36.72 \\
\hline & $033-22014$ & 1844411 & 363481 & -5265.38 & -5248.23 & -17.15 \\
\hline & $033-24080$ & 1845669 & 368493.5 & -5237.17 & -5159.48 & -77.68 \\
\hline & $033-22377$ & 1832509 & 359313.3 & -5426.01 & Outside & \\
\hline
\end{tabular}




\section{Appendix B. Allan Mapping Displacements for Along-strike Faults}

\begin{tabular}{|l|l|l|r|}
\hline Fault 1 & & & \\
\hline & Vertical & Horizontal & Apparent Slip \\
\hline Max & 134.2248 & 132.990224 & 156.835496 \\
\hline Min & 0 & 0 & 0 \\
\hline Mean & 76.79989 & 58.05928 & 86.124581 \\
\hline
\end{tabular}

\begin{tabular}{|l|r|l|r|}
\hline Fault 2 & & & \\
\hline & \multicolumn{1}{|c|}{ Vertical } & Horizontal & Apparent Slip \\
\hline Max & 181.1032 & 193.545584 & 222.127176 \\
\hline Min & 2.03996 & 0.49548008 & 2.59660216 \\
\hline Mean & 128.2152 & 101.029904 & 146.42412 \\
\hline
\end{tabular}

\begin{tabular}{|l|l|l|r|}
\hline Fault 3 & & & \\
\hline & Vertical & Horizontal & Apparent Slip \\
\hline Max & 117.5421 & 133.967992 & 151.851864 \\
\hline Min & 0 & 0 & 0 \\
\hline Mean & 66.35866 & 73.97712 & 85.457776 \\
\hline
\end{tabular}

\begin{tabular}{|l|r|r|r|}
\hline Fault 4 & & & \\
\hline & Vertical & Horizontal & Apparent Slip \\
\hline Max & 114.636 & 141.04 & 148.766696 \\
\hline Min & 0 & 0 & 0 \\
\hline Mean & 68.95774 & 73.95744 & 85.180944 \\
\hline
\end{tabular}

\begin{tabular}{|l|r|r|r|}
\hline Fault 5 & & & \\
\hline & Vertical & Horizontal & Apparent Slip \\
\hline Max & 114.8571 & 64.810504 & 123.59204 \\
\hline Min & 1.92864 & 0.5000688 & 0 \\
\hline Mean & 72.03011 & 37.251616 & 76.358728 \\
\hline
\end{tabular}

\begin{tabular}{|l|l|l|r|}
\hline Fault 6 & & & \\
\hline & Vertical & Horizontal & Apparent Slip \\
\hline Max & 161.0286 & 136.459808 & 182.936096 \\
\hline Min & 0 & 0 & 0 \\
\hline Mean & 102.1536 & 85.953056 & 116.798832 \\
\hline
\end{tabular}




\begin{tabular}{|l|l|r|r|}
\hline Fault 7 & & & \\
\hline & Vertical & Horizontal & \multicolumn{1}{c|}{ Apparent Slip } \\
\hline Max & 168.1148 & 162.594848 & 204.200664 \\
\hline Min & 4.293651 & 3.3765304 & 4.6521552 \\
\hline Mean & 86.33222 & 72.602472 & 101.400544 \\
\hline
\end{tabular}

\begin{tabular}{|l|l|r|r|}
\hline Fault 8 & & & \\
\hline & Vertical & Horizontal & Apparent Slip \\
\hline Max & 144.0156 & 204.900616 & 193.627912 \\
\hline Min & 0.524219 & 4.1078064 & 0.59204328 \\
\hline Mean & 89.36327 & 120.427496 & 116.632208 \\
\hline
\end{tabular}

\begin{tabular}{|l|l|r|r|}
\hline Fault 9 & & & \\
\hline & Vertical & Horizontal & Apparent Slip \\
\hline Max & 91.84951 & 97.467496 & 115.770224 \\
\hline Min & 0 & 0 & 0 \\
\hline Mean & 52.51542 & 56.498 & 65.472736 \\
\hline
\end{tabular}

\begin{tabular}{|l|l|r|r|}
\hline Fault 10 & & & \\
\hline & Vertical & Horizontal & Apparent Slip \\
\hline Max & 48.77426 & 98.0556 & 88.39928 \\
\hline Min & 1.201054 & 1.86477512 & 2.32105264 \\
\hline Mean & 33.43173 & 57.419024 & 56.32416 \\
\hline
\end{tabular}

\begin{tabular}{|l|l|r|r|}
\hline Fault 11 & & & \\
\hline & Vertical & Horizontal & Apparent Slip \\
\hline Max & 34.50658 & 23.137612 & 37.324104 \\
\hline Min & 0 & 0 & 0 \\
\hline Mean & 14.15018 & 8.975228 & 14.6464464 \\
\hline
\end{tabular}





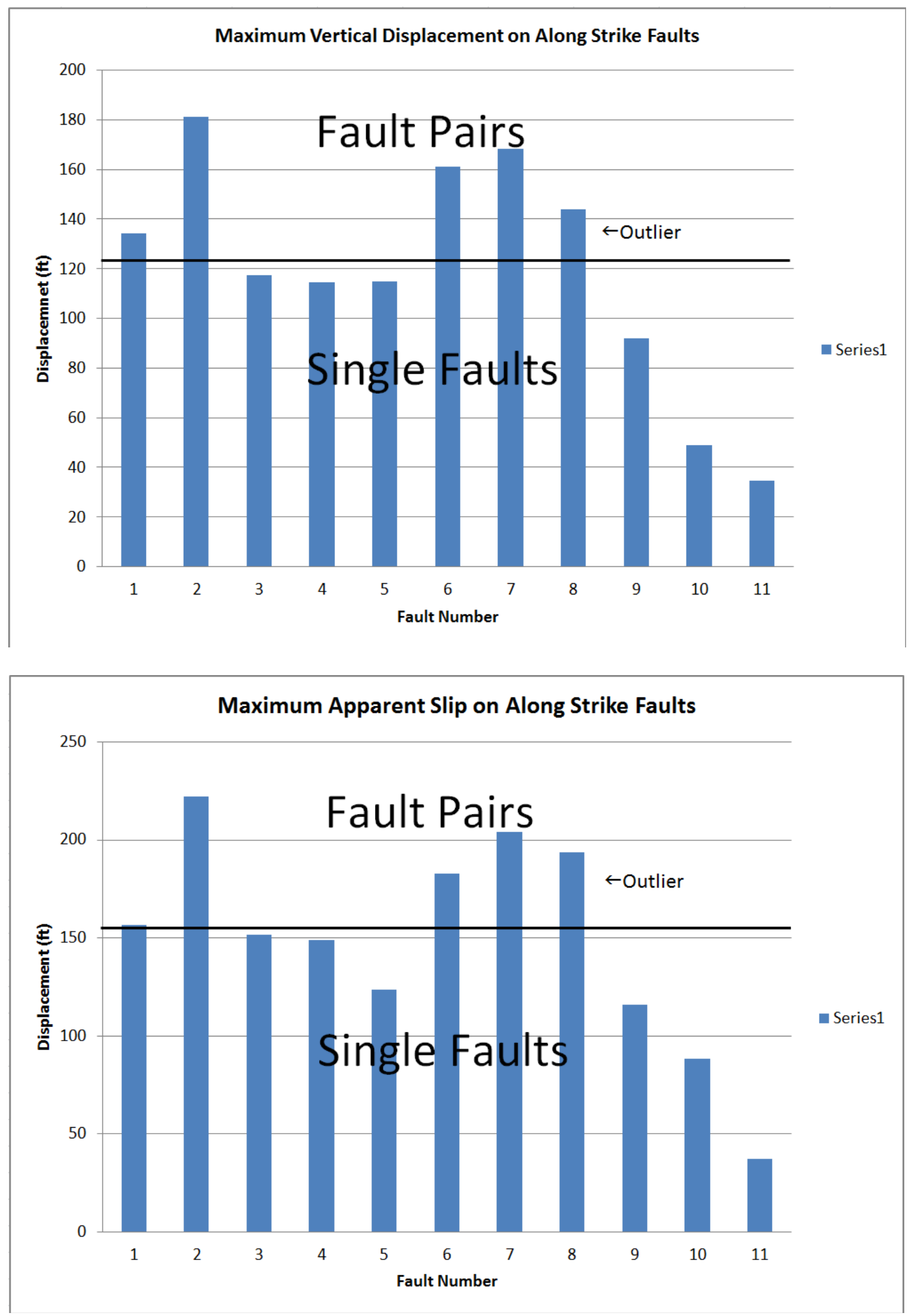


\section{Appendix C. B-value Histograms}

\section{Stage 1 B-value Histogram}



Stage 2 B-value Histogram

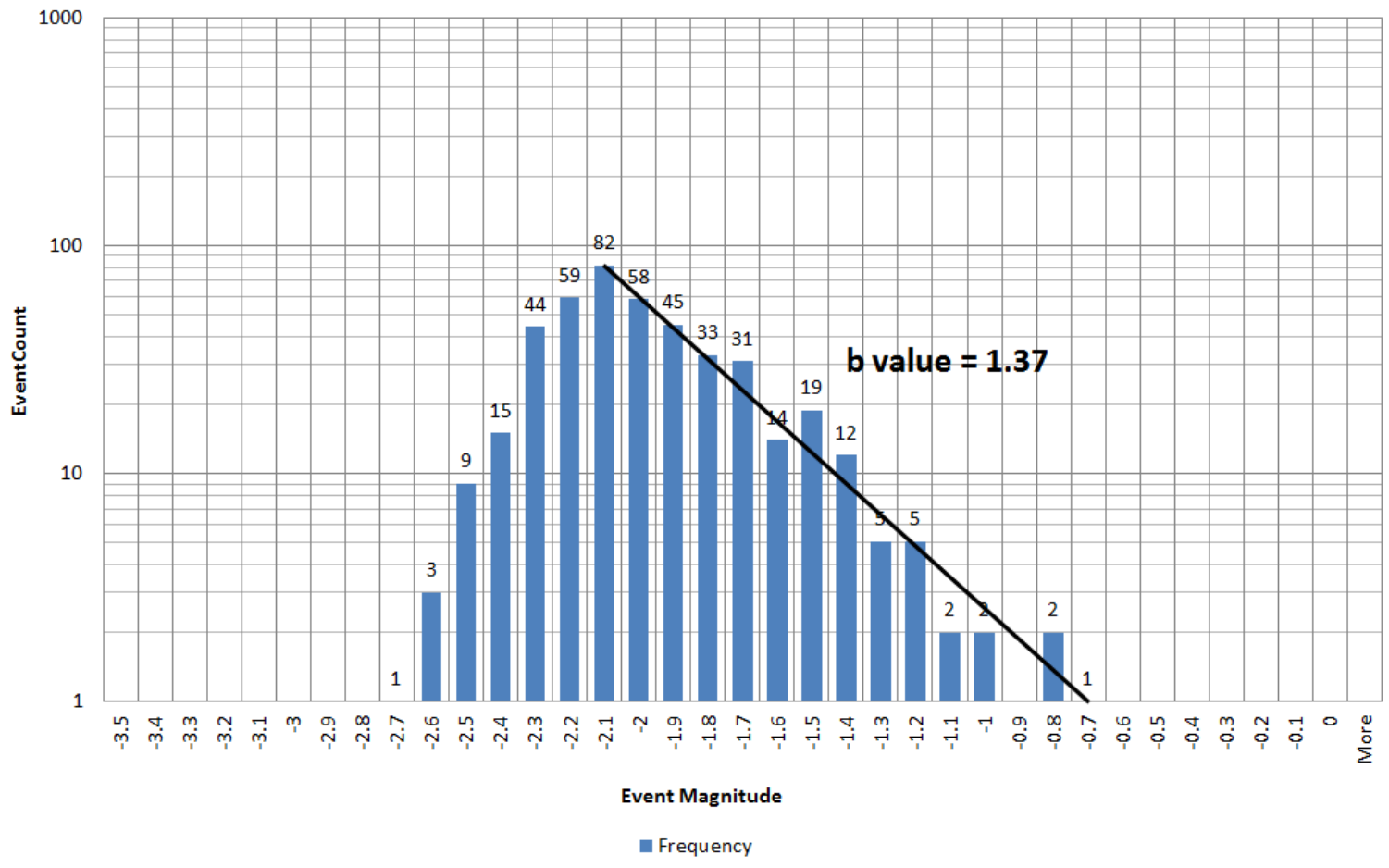


Stage 3 B-value Histogram

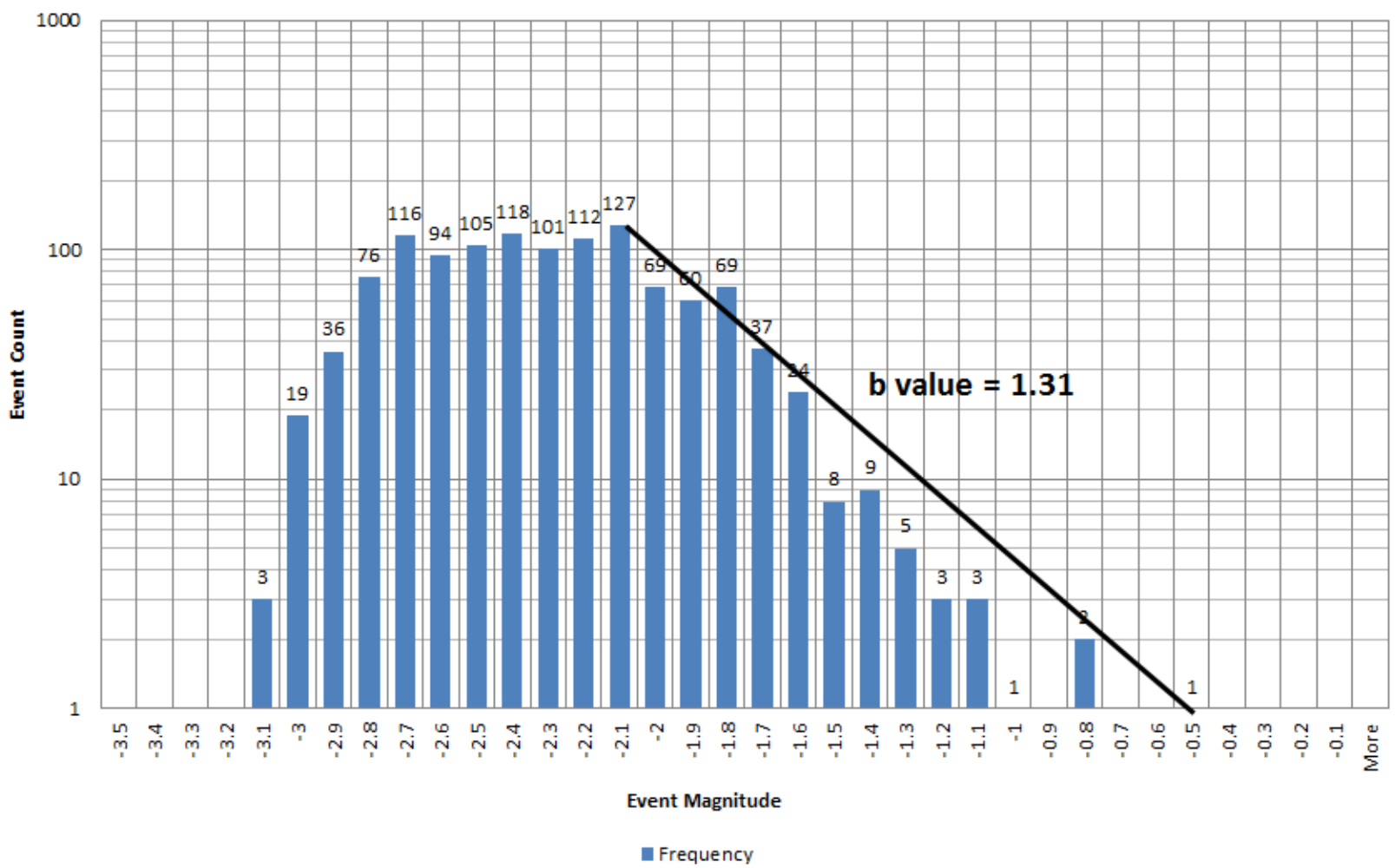

Stage 4 B-value Histogram

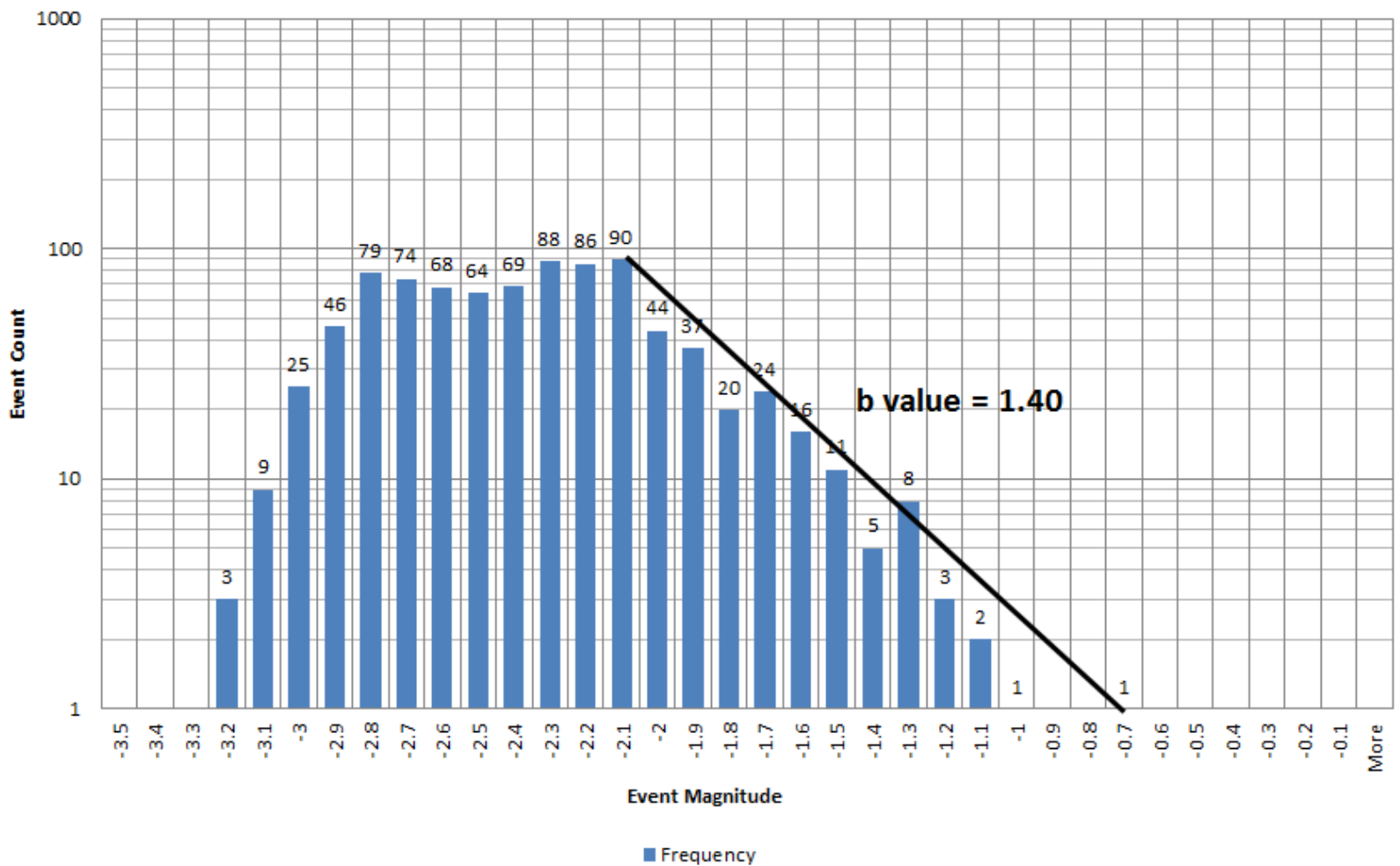


Stage 5 B-value Histogram

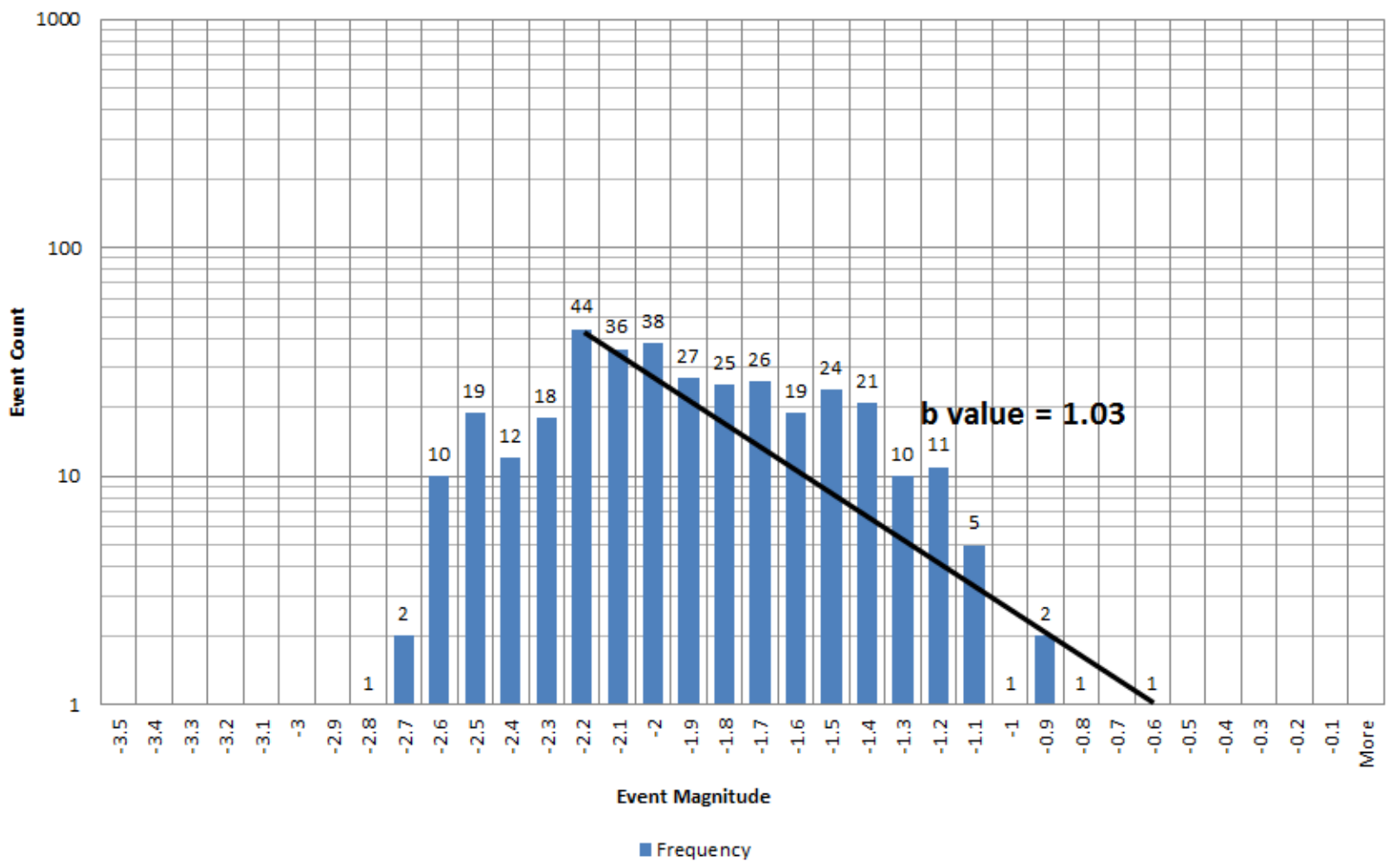

Stage 6 B-value Histogram

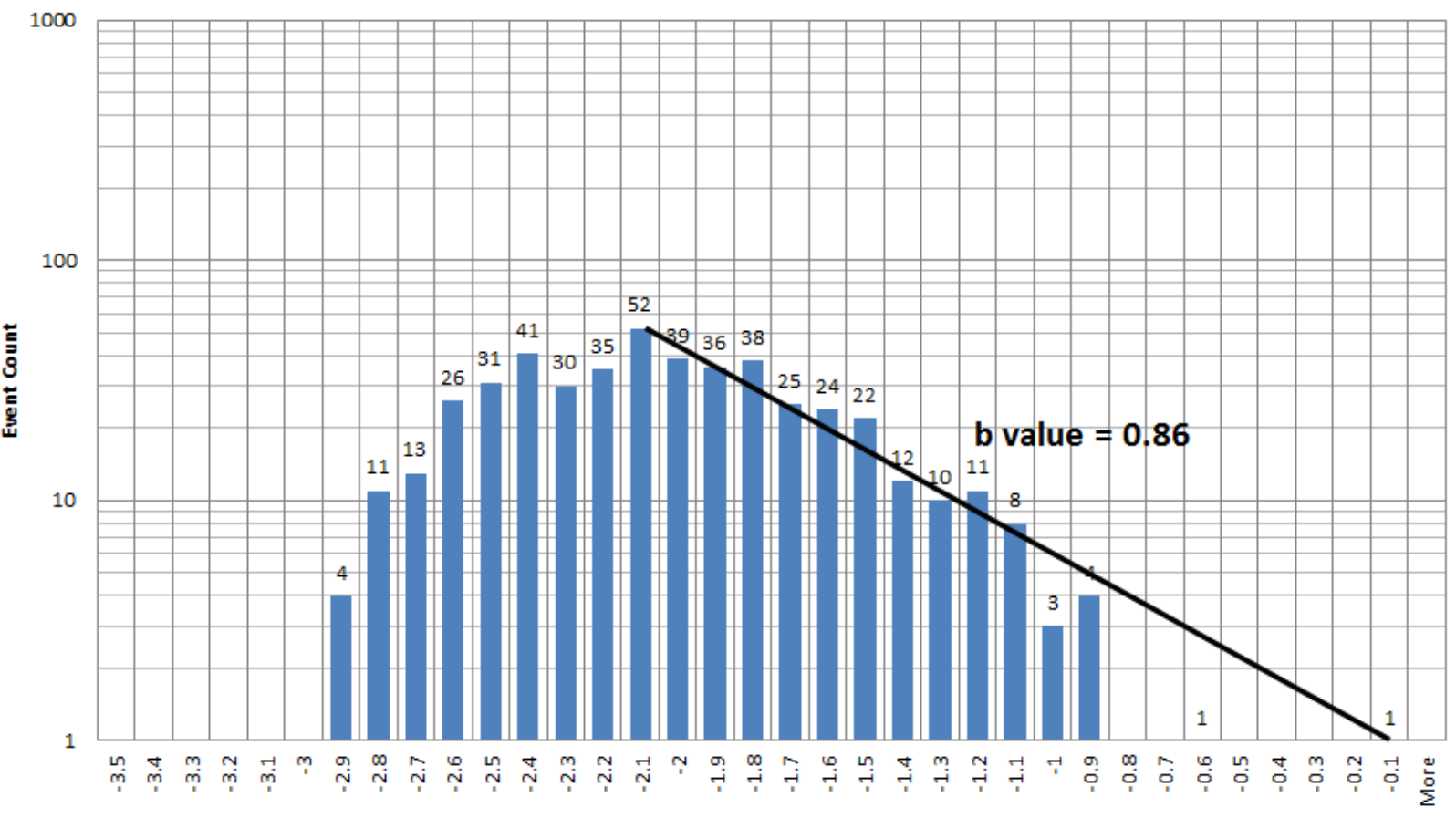

Event Magnitude

Erequency 
Stage 7 B-value Histogram

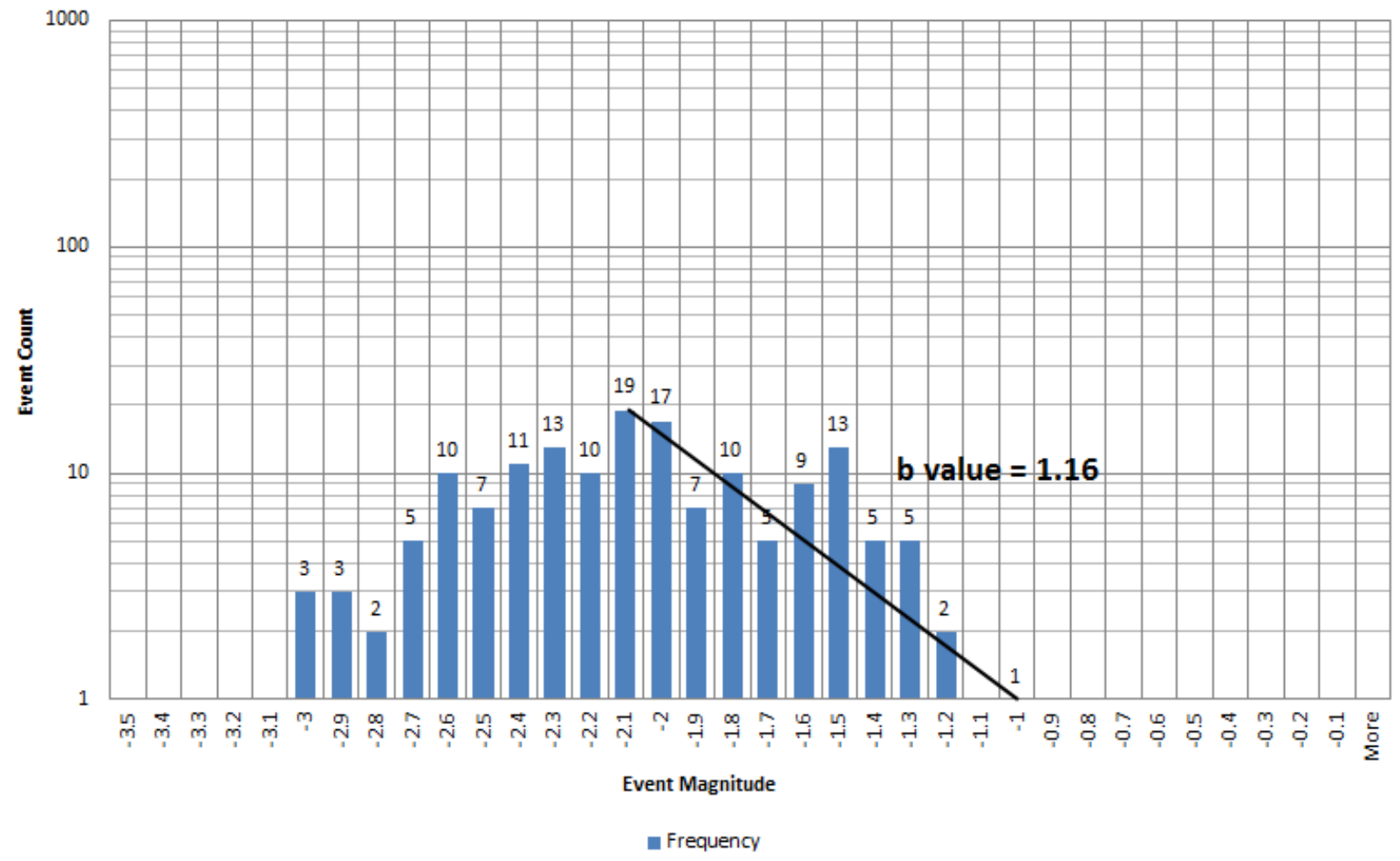

\section{Stage 8 B-value Histogram}

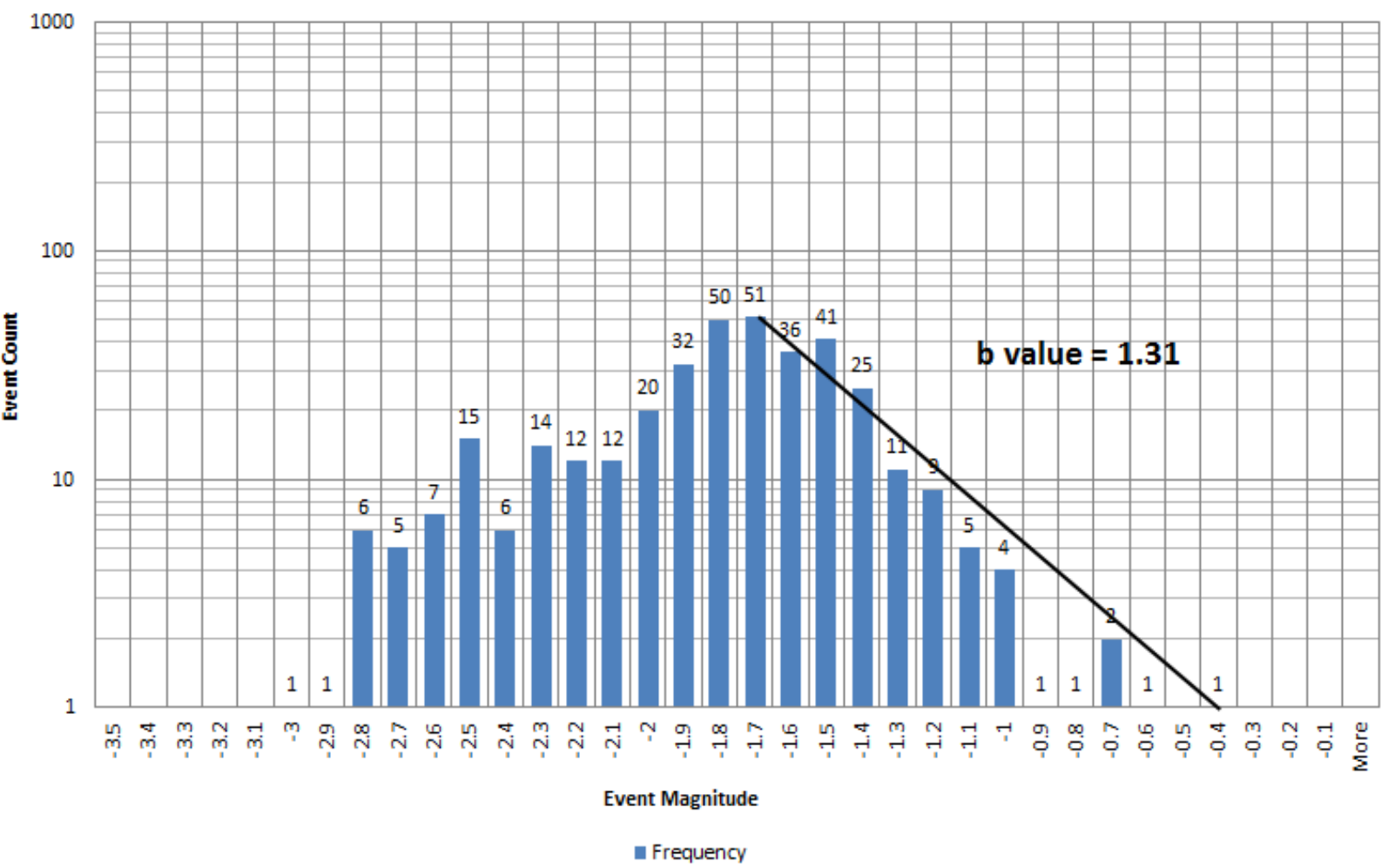




\section{Stage 9 B-value Histogram}

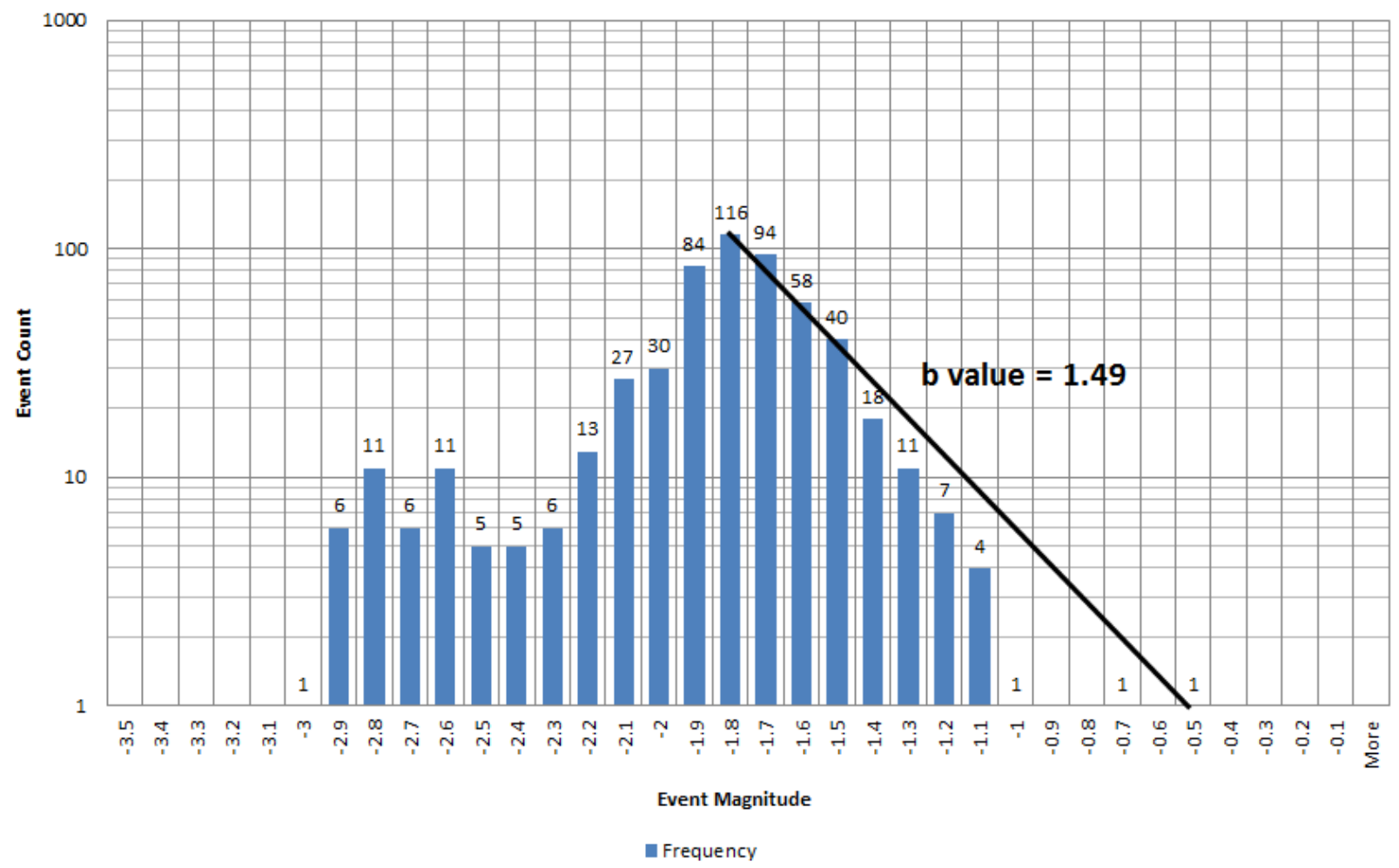

Stage 10 B-value Histogram

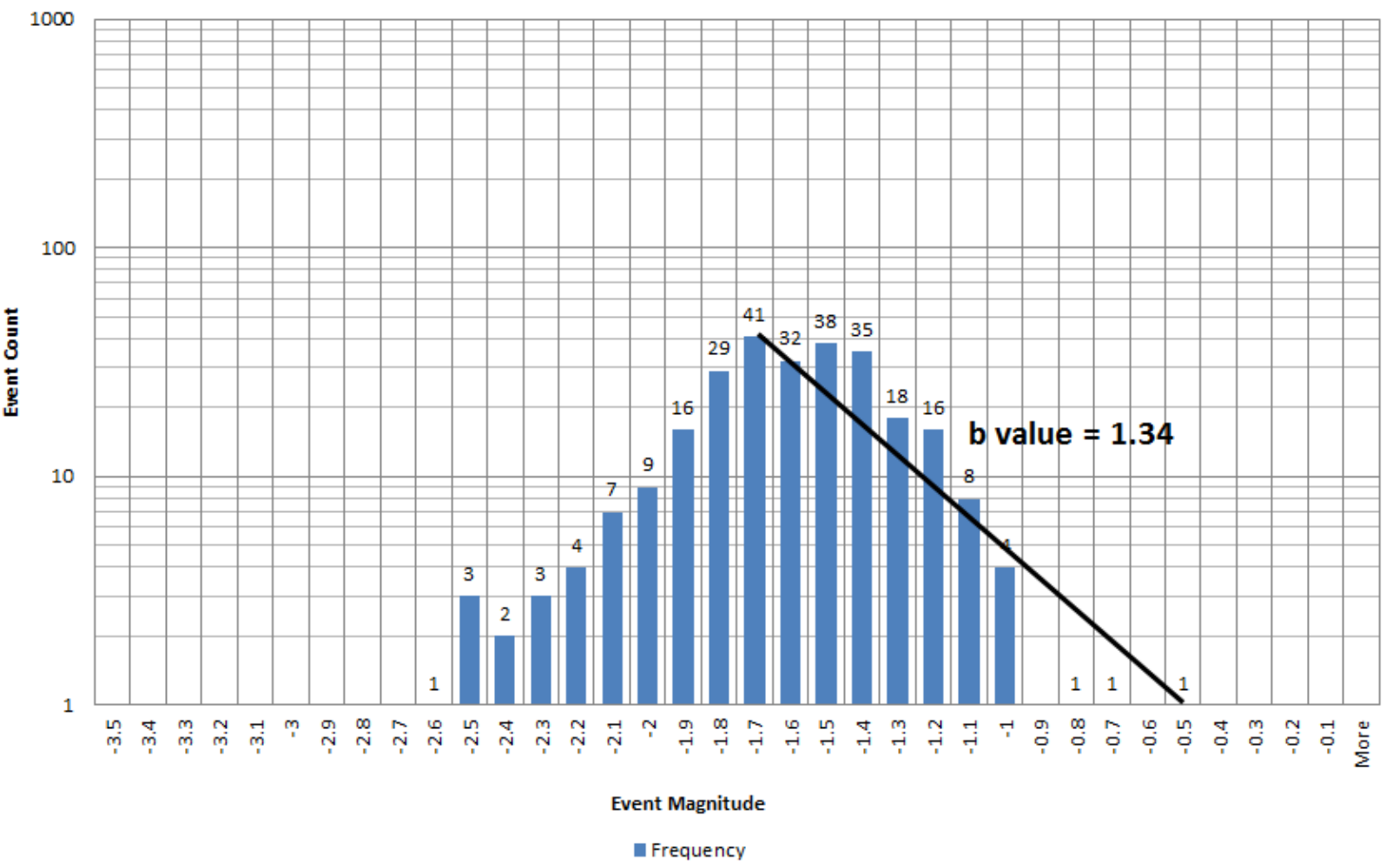


Stage 11 B-value Histogram

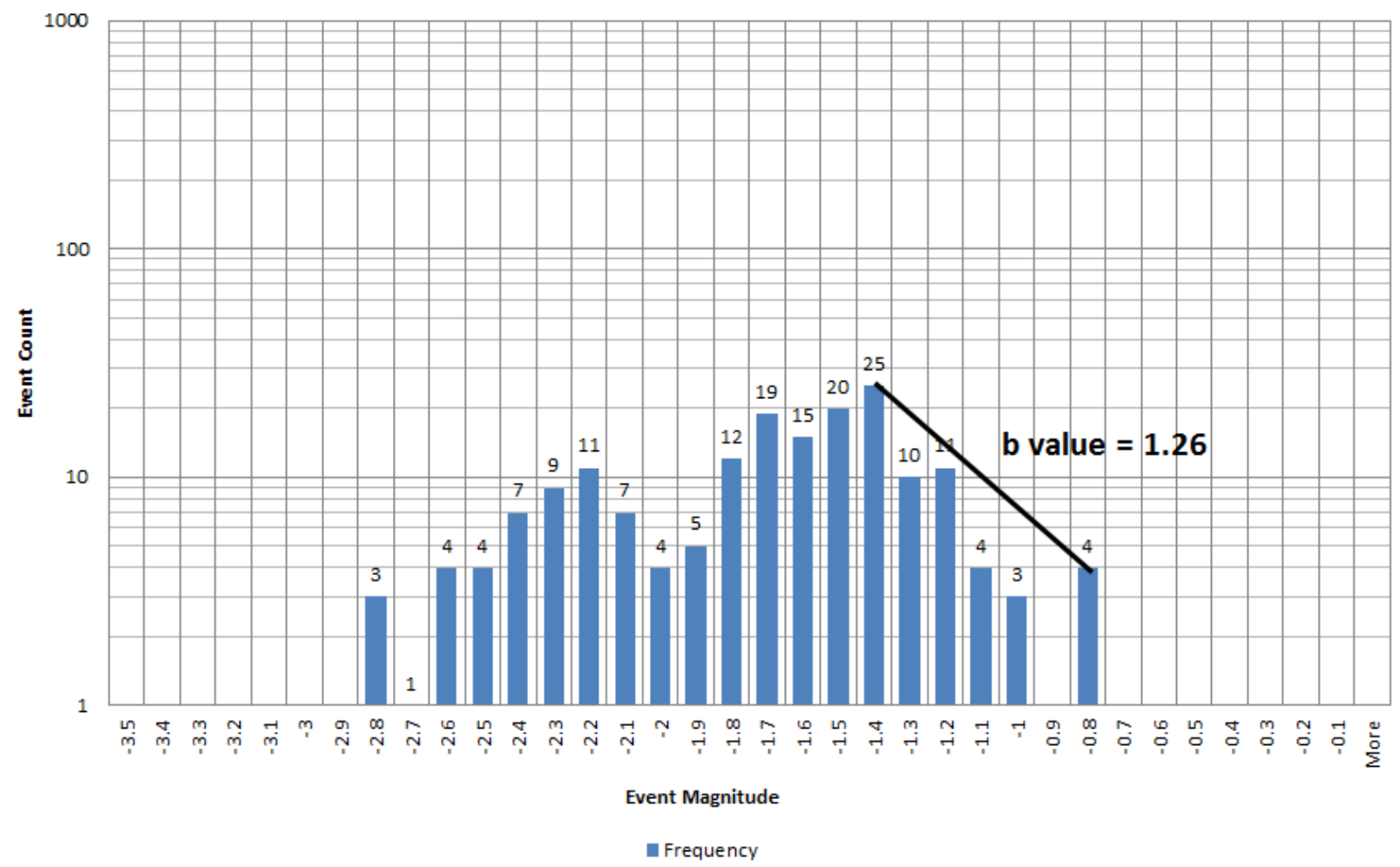

Stage 12 B-value Histogram

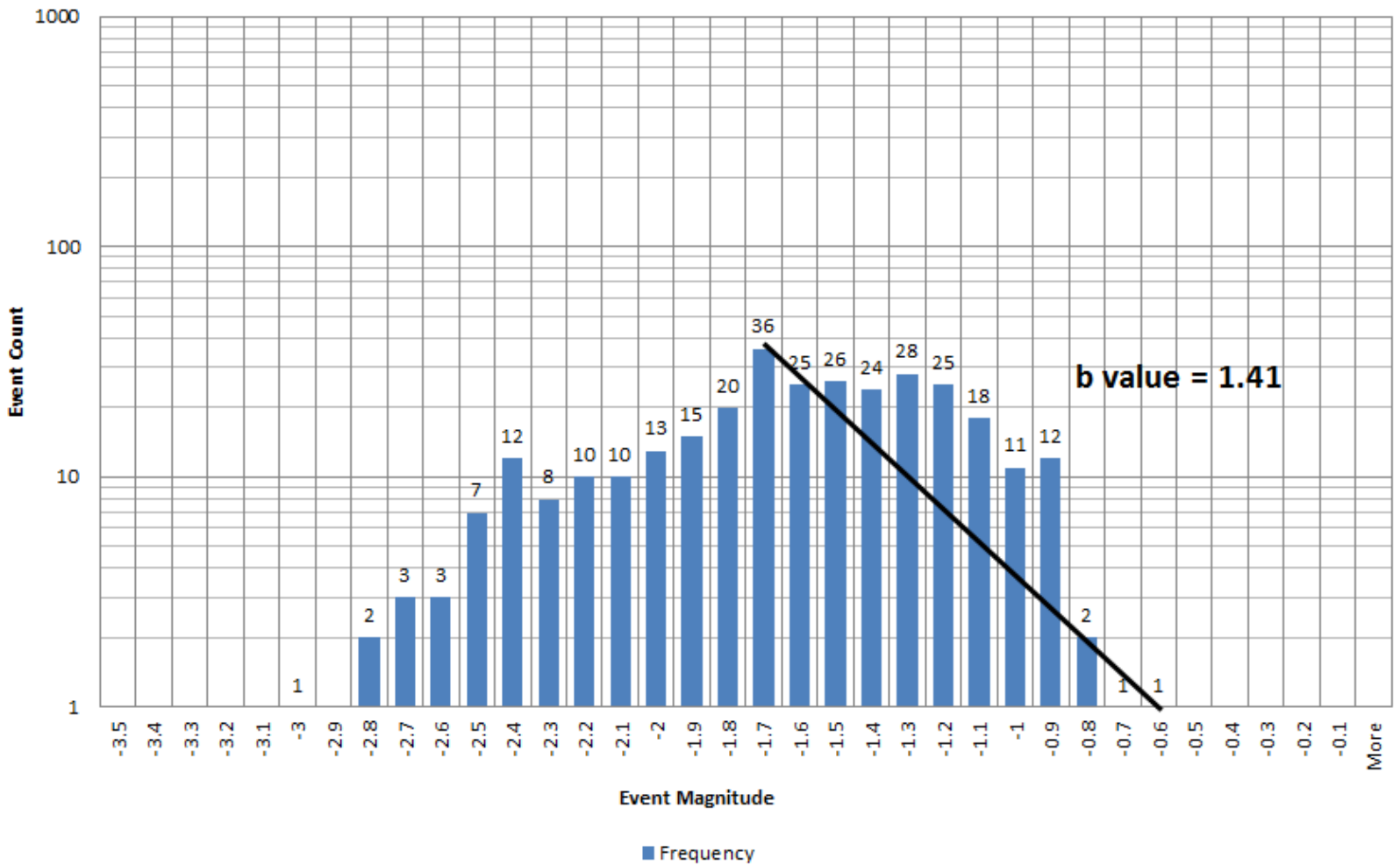




\section{Stage 13 B-value Histogram}

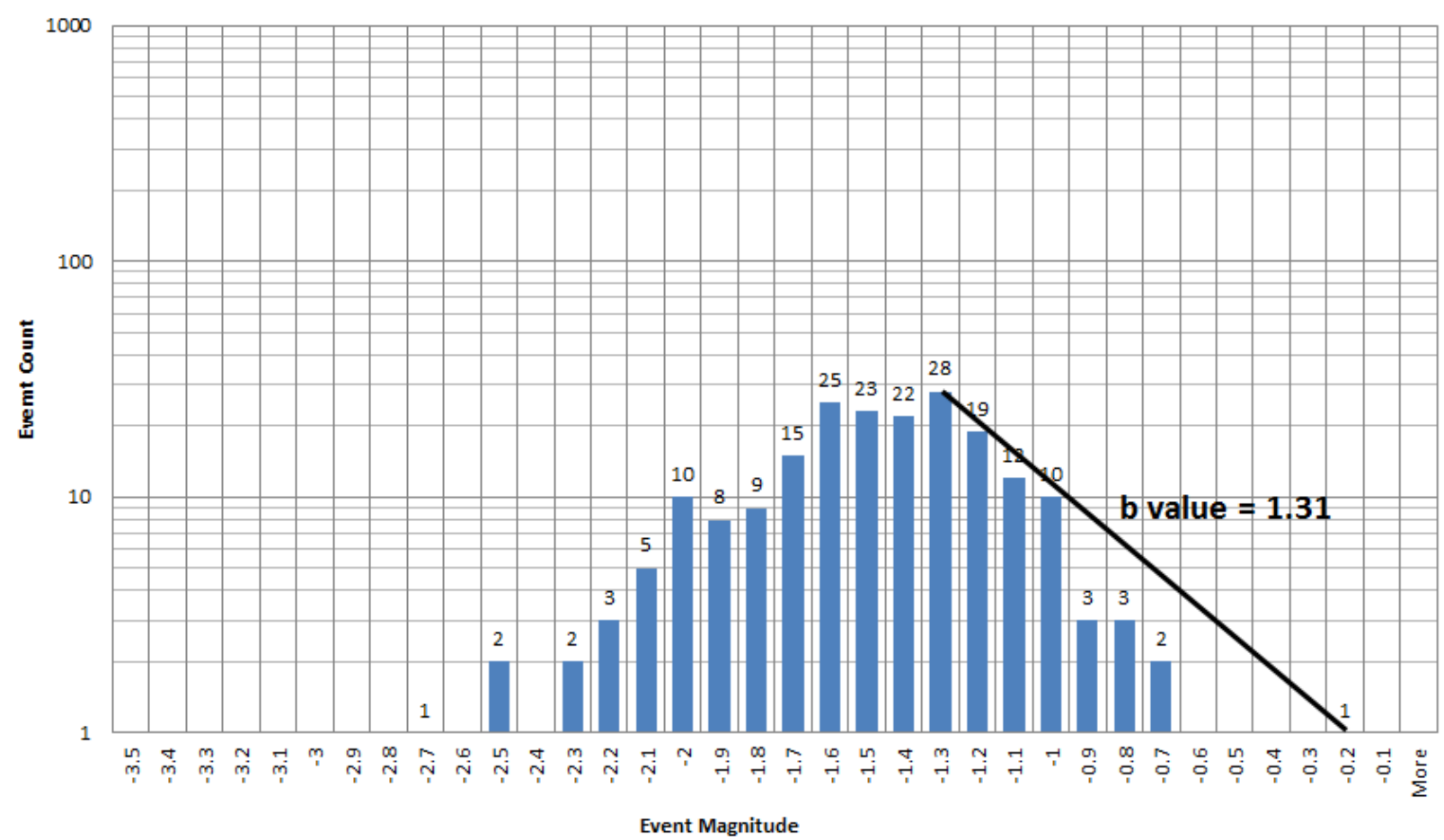

- Frequency 